\title{
Stem Cells, Self-Renewal, and Lineage Commitment in the Endocrine System
}

\begin{abstract}
Katia Mariniello ${ }^{1}$, Gerard Ruiz-Babot ${ }^{2,3}$, Emily C. McGaugh 4,5, James G. Nicholson ${ }^{1}$, Angelica Gualtieri ${ }^{1}$, Carles Gaston-Massuet ${ }^{1}$, Maria Cristina Nostro ${ }^{4,5}$ and Leonardo Guasti ${ }^{1 *}$

${ }^{1}$ Centre for Endocrinology, William Harvey Research Institute, Bart's and the London School of Medicine and Dentistry, Queen Mary University of London, London, United Kingdom, ${ }^{2}$ Division of Endocrinology, Boston Children's Hospital, Boston, MA, United States, ${ }^{3}$ Harvard Stem Cell Institute, Cambridge, MA, United States, ${ }^{4}$ McEwen Stem Cell Institute, University Health Network, Toronto, ON, Canada, ${ }^{5}$ Department of Physiology, University of Toronto, Toronto, ON, Canada
\end{abstract}

The endocrine system coordinates a wide array of body functions mainly through secretion of hormones and their actions on target tissues. Over the last decades, a collective effort between developmental biologists, geneticists, and stem cell biologists has generated a wealth of knowledge related to the contribution of stem/progenitor cells to both organogenesis and self-renewal of endocrine organs. This review provides an up-to-date and comprehensive overview of the role of tissue stem cells in the development and self-renewal of endocrine organs. Pathways governing crucial steps in both development and stemness maintenance, and that are known to be frequently altered in a wide array of endocrine disorders, including cancer, are also described. Crucially, this plethora of information is being channeled into the development of potential new cell-based treatment modalities for endocrine-related illnesses, some of which have made it through clinical trials.

Keywords: stem cells, development, self-renewal, regenerative medicine, plasticity

\section{INTRODUCTION}

Stem cells are endowed with the ability to self-renew and differentiate into various organ-specific cell types. They are mainly active during embryogenesis where complex autocrine, paracrine, and endocrine interactions govern their fate, proliferation, and gradual differentiation toward highly organized tri-dimensional organs. A growing number of evidence indicates that populations of stem cells are retained in most post-natal tissues (somatic or adult stem cells), where they exert essential functions throughout life, namely tissue maintenance/self-renewal, remodeling/plasticity in response to physiological demands as well as repair. By definition, adult stem cells have the ability to self-renew, however their differentiation potential is restricted to the array of specialized cell types corresponding to the organ in which they reside. The plasticity of the endocrine organs has been recognized only recently, and our understanding has been propellered by (i) the use of specific genetic mouse models, (ii) gene-discovery approaches for endocrine disorders, and (iii) reprogramming strategies to obtain functional endocrine cells. The acquired knowledge of the biology of endocrine organs is not only important for our understanding of pathological processes, but also for the potential application of cell-based therapies or restoration of stem cell function. 
In this review, the role of stem cells in the endocrine system will be covered, from the perspective of tissue development and their function in tissue maintenance and organ plasticity. Recent data showing potential to harness the properties of stem cells for clinical applications is also reviewed.

\section{THE PITUITARY GLAND}

\section{Endocrine Function in the Pituitary Gland}

The pituitary gland is a small endocrine organ connected to the hypothalamus and together they form the hypothalamopituitary axis (HPA), which regulates vital physiological functions such as growth, reproduction, lactation, metabolism, and stressresponses (1). The pituitary gland can be separated into adenohypophysis (anterior pituitary), including both the anterior lobe (AL) and intermediate lobe (IL) derived from oral ectoderm, and the neurohypophysis (posterior pituitary) also known as the posterior lobe (PL) derived from neural ectoderm. In rodents the two lobes remain distinct and are separated by a cleft, with an epithelial lining known as the marginal zone (MZ). The PL is populated by the axonal termini of hypothalamic magnocellular neurons which release anti-diuretic hormone and oxytocin into the blood circulation. The AL develops from oral ectoderm and harbors five cell types: lactotrophs, producing prolactin (PRL); somatotrophs, which release growth hormone $(\mathrm{GH})$; corticotrophs, which synthesize adrenocorticotrophic hormone (ACTH); thyrotrophs, secreting thyroid-stimulating hormone (TSH); and finally, gonadotrophs, which release luteinizing hormone (LH) and follicle-stimulating hormone (FSH). A further population of hormone secreting cells, melanotrophs, are found in the IL and are responsible for the synthesis of melanocyte-stimulating hormone (MSH).

\section{Key Pathways Guiding Pituitary Gland Development}

The development of the pituitary gland can be separated into three sequential steps, cell specification, cell lineage commitment and terminal differentiation (Figure 1). In mice, pituitary organogenesis begins at embryonic day (e) 8, with a thickening of a region of the oral ectoderm, known as the hypophyseal placode (HP) within the anterior neural ridge (ANR) and adjacent to the ventral diencephalon (VD). By e9, an epithelial invagination of the oral ectoderm, centered at the HP occurs forming a rudimental pouch known as Rathke's pouch (RP) (2). This process is directed by physical contact with the overlaying region of the VD known as the infundibulum, which eventually gives rise to the hypothalamic median eminence, the pituitary stalk and the PL (3). By e10.5 the infundibulum begins to evaginate toward the RP and tightly regulated apoptosis separates the RP from the underlying oral ectoderm (4). The lumen of the RP is surrounded by a highly proliferative epithelial layer of pituitary stem/progenitor cells (PSCs) (5). This cell population undergoes a rapid expansion between e11.5 and e13.5 during which the majority of endocrine cell precursors are generated (6). As these $\mathrm{RP}$ progenitors gradually exit the mitotic cycle, they express cell cycle inhibitors such as p57 $7^{\mathrm{KIP} 2}$ and $\mathrm{p} 27^{\mathrm{KIP} 1}$ and lose their epithelial characteristics in order to give rise to distinct pituitary cell types (7). By e14.5 PSCs are committed to one of the three endocrine lineages (expressing transcription factors T-box Factor 19, Pituitary (Tpit) (8), or POU domain, class 1, transcription factor 1 (Pit1)(9) or Steroidogenic Factor 1 (Sf1) (10), and as they begin to differentiate they migrate ventrally and laterally away from the RP lumen, forming the bulk of the AL, with the dorsal progenitors of the RP forming the IL. The residual luminal space of the RP, known as the cleft, and the periluminal MZ constitutes a stem cell niche where multipotent PSCs are maintained into adulthood (11-13). Terminal differentiation culminates shortly after birth when, in rodents, the pituitary gland undergoes a sustained perinatal period of proliferation and growth (14).

Patterning of the developing embryo and induction of the pituitary primordium are regulated by a complex array of sequentially expressed signaling molecules and morphogens. Together, these act to demarcate different regions of the VD (15) and control the developmental induction of the pituitary gland. Bone morphogenetic protein-4 (Bmp4) is expressed and secreted from the VD from e8.5; there it functions as an essential extrinsic requirement for RP formation, and its expression is maintained in the infundibulum up to e14.5 (16-19). Through induction of T-box transcription factor 2 (Tbx2), Bmp4 represses the expression of the morphogen sonic hedgehog (Shh) (20) and opposing gradients of Bmp4 and Shh define the infundibular region of the $\mathrm{VD}$ ensuring correct positioning of the RP. From e10.5 Bmp2 is expressed in the developing RP and is essential for $\mathrm{RP}$ maintenance and progenitor proliferation, before expression is lost by e14.5 $(6,16,17)$. Fibroblast growth factor (Fgf)- 8, 10 , and -18 are also expressed in the developing VD, appearing shortly after Bmp4 and maintained until e14.5 (17, 19, 21). Fgfs secreted by the VD activate the MAPK signaling pathway to promote the maintenance and proliferation of the dorsal region of the RP (6). Shh expression in the VD depends on SRY-box transcription factor 2 (Sox2) and Sox3 (22), and ensures the correct patterning of the region. The reciprocal inhibition of Shh and Bmp4 is required for correct infundibular positioning and induction of the RP. Consequently, ablation of Shh expression in the VD has been shown to cause altered expression of Bmp4, Wnt5a, and Fgf8 and a complete arrest in pituitary formation from the early stages of development $(23,24)$. Within the RP itself, Shh signaling is involved in progenitor proliferation as revealed by conditional deletion of its downstream transcriptional repressors Gli2 and Gli3 (25). Notch signaling in pituitary development appears important for infundibular morphogenesis, as mice null for the known target of Notch, Hairy and Enhancer of Split-1 (Hes1) have reduced evagination and disrupted development of the posterior lobe (2629). Within the RP, Notch signaling is initially widespread and later restricted to the $\mathrm{MZ}(29,30)$. There it promotes progenitor proliferation and maintenance (31), suppresses melanotroph and corticotroph differentiation (32) and promotes the emergence of the Pit1 lineage through integration with the transcription factor Homeobox Protein prophet of Pit1 (Prop1) (29, 33).

Wnt5a is expressed in both the VD and RP from e9.5 to e12.5 and is necessary for correct VD patterning, and indirectly for RP induction via non-canonical pathway (34). Wnt4 also signals via the non-canonical Wnt pathway, is expressed exclusively in the 


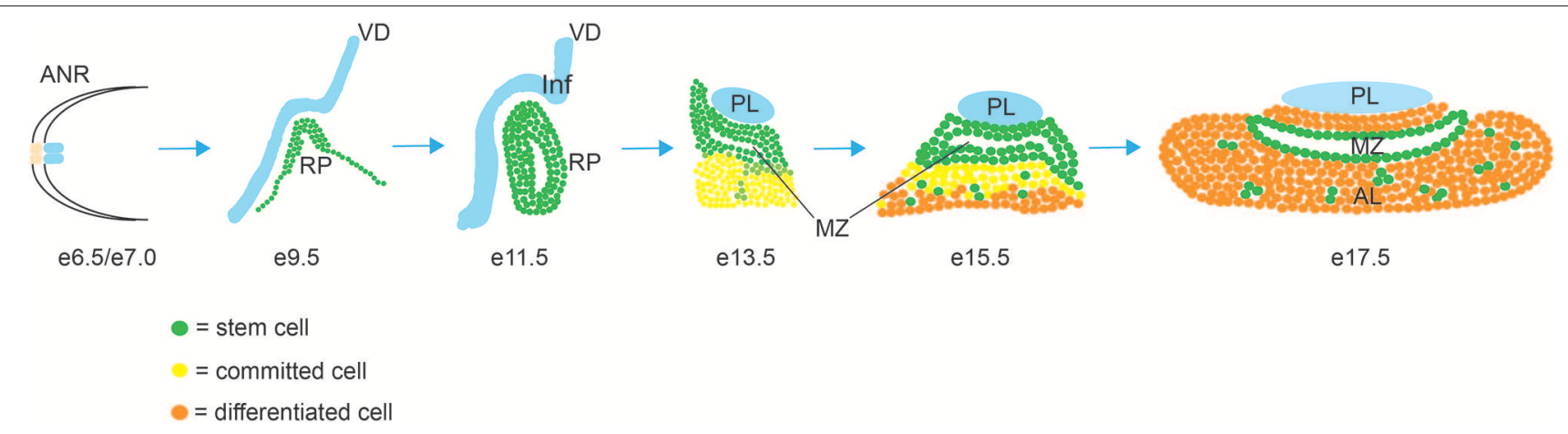

FIGURE 1 | Morphogenesis of the mouse pituitary gland. Abbreviations: AL, anterior lobe; ANR, anterior neural ridge; IL, intermediate lobe; Inf, infundibulum; MZ, marginal zone; PL, posterior lobe; RP, Rathke's Pouch; VD, ventral diencephalon.

$\mathrm{RP}$, and appears to function in cell commitment since its deletion reduces the expression of Pit1 resulting in fewer somatotrophs, lactotrophs, and thyrotrophs (34). Canonical Wnt/ $\beta$-catenin also plays an important role in pituitary development, and conditional gain or loss of function studies of $\beta$-catenin within the VD showed its role in regulating the expression of Fgf8, necessary for normal RP development (35). Within the RP, $\beta$ catenin has a role in Pitx2 activation stimulating progenitor proliferation (36) and later binds Prop1 and is necessary for the emergence of Pitl lineage of endocrine cells (37). Further downstream of Wnt signaling, the transcription factor binding partners of $\beta$-catenin, Transcription factor Tcf3, Tcf4, and Lymphoid Enhancer Binding Factor 1 (Lef1), also play a role in pituitary development. Tcf3 acts as a repressor of the Wnt/ $\beta$-catenin pathway in the anterior forebrain (38) and is essential for the development of the HPA in both human and mice (39). Tcf4 genetic ablation leads to an increase in early progenitor proliferation with increased and prolonged expression of Prop1, which can lead to aberrant tissue growth and tumor formation if not down-regulated (40-42). Genetic ablation of Lef1 does not have similarly pronounced effects, but its inhibition reduces Pit1 expression indicating a potential role as a repressor of pituitary differentiation $(37,43)$. The $\mathrm{Wnt} / \beta$-catenin pathway is important in PSC proliferation and maintenance and deregulation of this pathway lead to stem cell-derived pituitary tumors. Activating mutations in $\beta$-catenin drive adamantinomatous craniopharyngioma both in mouse and humans $(44,45)$ and PSC Sox $2^{+}$cells have been shown to be the tumor initiating cells that are responsive to oncogenic $\beta$-catenin.

In addition to the role of morphogens and signaling pathways, the spatiotemporal expression patterns of transcription factors during pituitary development have also been extensively studied, particularly in the context of congenital forms of hypopituitarism (Figure 2) (46). The paired-like homeodomain transcription factor Homeobox Expressed in ES cells 1 (Hesx1) functions as a transcriptional repressor through its interaction with the transcriptional corepressor Transducin-Like Enhancer of Split 1 (Tle1) and is an important regulator of forebrain development (47). It is also crucial for early pituitary development, with Hes $\mathrm{X}^{-/-}$mice showing multiple clefts and over proliferation
(48). Importantly, in the RP Hesx1 represses Prop1 expression until e13.5 (48) when it is reciprocally downregulated by the Prop $1 / \beta$-catenin complex (37). Hesx1 also acts as a repressor of the Wnt pathway, and it has been suggested that de-repression of the Wnt pathway in the anterior neural plate and RP underlies the phenotype of Hesx $1^{-/-}$mice $(48,49)$. The closely related Sine Oculis homeobox (Six) transcription factors Six3 and Six6 are expressed in both the VD and RP, with Six6 expression maintained in the adult pituitary. Knockout studies have revealed that both transcription factors are involved in the regulation of progenitor proliferation, with Six6 acting a repressor of the cell cycle inhibitor p27KIP1 (50), and Six3 serving as a repressor of $\mathrm{Wnt} / \beta$-catenin signaling (49). The paired homeodomain proteins, Pitx1 and Pitx2, are two additional important regulators of pituitary development expressed in the RP where they function redundantly in the maintenance of RP progenitors (4) and later play a role in thyrotroph function (51). Three different members of the LIM-homeodomain transcription factors (Lhx2, 3 and 4) are expressed during pituitary development. Lhx2 is expressed throughout the RP and VD, and appears to function in formation of the infundibulum, but is not involved in cell differentiation (52). By contrast Lhx3 and Lhx4 are expressed from e9.5 in the RP and are redundantly required for progenitor maintenance, and later at e14.5 $\mathrm{Lhx} 4$ is downregulated whilst Lhx3 expression is required for endocrine differentiation and maintained into adulthood (53). As stated above, Sox2 and Sox3 are expressed in the VD where they activate the expression of Shh $(22)$ and of Six3/Six6 proteins $(54,55)$. Sox3 loss of function mutations can result in mild hypopituitarism (56), as can Sox2 haploinsufficiency (57). In both So $3^{-/-}$and Sox $2^{+/-}$mice the $\mathrm{RP}$ is bifurcated, and at least for Sox $3^{-/-}$mutants this has been associated with expanded Bmp4 and Fgf8 domains in the VD $(57,58)$. This is likely a consequence of downregulation of Shh (22) and perhaps Six3/6 also $(54,55)$. Prop1 represents the earliest pituitary specific marker; it is first expressed at e10, and maintained throughout development in the Sox $2^{+}$ progenitor cells, before rapid post-natal downregulation in all but a few Sox $2^{+}$PSCs (59-61). Prop $1^{-/-}$mice have reduced Pit1 expression, and prolonged Hesx 1 expression resulting in the loss of somatotrophs, lactotrophs, and thyrotrophs (59, 60, 62). An 
important role of Prop1 is the regulation of the epithelial-tomesenchymal transition as progenitor cells migrate away from the residual RP lumen and begin to undergo differentiation. In the absence of Prop1, progenitors fail to populate the anterior lobe resulting in a dysmorphic pituitary gland by e14.5 $(63,64)$.

Progenitor endocrine cell lineage commitment is defined by the expression of three essential transcription factors Pit1, Tpit, and Sf1 (Figure 2). The process of differentiation relies on the activity of at least two epigenetic regulators, the histone demethylase Lsd1 (65), and the zinc finger protein Insm1 (66). Pit1 expression is activated by Prop1, in complex with $\beta$ catenin (37) and is required for the differentiation as well as the expansion and survival of lactotrophs, somatotrophs and thyrotrophs $(67,68)$. Somatotrophs are further specified by Neurod4 (29), and the Notch ligand Delta-Like homolog 1 (Dlk1) (69). In contrast lactotrophs are predominately specified by estrogen signaling (70). Thyrotrophs can first be identified by the expression of the transcription factor Forkhead Box L2 (Foxl2) and then $\alpha$-Glycoprotein Subunit ( $\alpha$ GSU) (19). Both are also expressed in gonadotrophs. Subsequently, Gata2 is expressed which can activate the expression of Chromogranin-A (Cga) (71). Gonadotrophs are broadly similar to thyrotrophs in terms of their expression of lineage commitment markers but can be differentiated by their expression of Gonadotropin Releasing Hormone Receptor Gnrhr (72) and later Sf1 which promotes the expression of Cga, Fsh and Lh (73). Corticotrophs and melanotrophs emerge from the Tpit (Tbx19) lineage $(74,75)$ which are further defined by their expression of the transcription factors Neuronal Differentiation 1 (NeuroD1) (76) and Paired Box 7 (Pax7) (77), respectively.

\section{Stem Cells in the Developing and Adult Pituitary Gland}

The past decade has seen a great deal of interest in the characterization of PSCs and their function through development to the maintenance of the adult gland, under normal physiological conditions, periods of endocrine stress or in pituitary disease (78-83). They are primarily identified by their expression of Sox2, which drives rapid proliferation in the lumen of RP during early development (84). By e13.5 the surge in pituitary precursor proliferation subsides and Sox 9 is expressed alongside Sox 2 in a subpopulation of PSCs (85). The AL also harbors a secondary stem cell niche with clusters of Sox $2^{+}$PSCs scattered through the parenchyma $(46,86)$. Functional analysis of PSCs from these two different niches did not reveal obvious differences (87). Intriguingly these two disparate populations of PSCs appear to be physically interconnected to form a threedimensional network, an architectural feature that hints at some, as of yet undescribed, concerted function (88).

Building upon early in vitro studies (12), more recent in vivo lineage tracing studies have demonstrated the multipotency of Sox $2 /$ Sox $9^{+}$embryonic and adult PSCs and their contribution to tissue homeostasis $(85,89)$. Intriguingly, under normal physiological conditions adult PSCs are highly quiescent and largely inactive $(15,17,19,23)$, which may reflect the low tissue turnover rate of adult pituitary cells, relative to tissues with more active stem cell pools (24); this questions the notion of tissue maintenance as their function (17), particularly since major depletion of adult PSCs did not affect tissue homeostasis (90). More likely their primary function is to provide the organ with plasticity and some regenerative capacity. Genetic ablation of different endocrine cell populations induces PSCs activation and replenishment of $\sim 60 \%$ of the targeted hormone secreted cell type (25-28). However, this regenerative capacity is limited, as it tails off rapidly with age (28) and there is at least some contribution from endocrine cell proliferation and trans-differentiation (26). Perhaps more importantly, PSCs are also able to respond to physiological demand under periods of endocrine stress: for instance, experimental adrenalectomy leads to increases in Sox $2^{+}$PSCs-derived corticotrophs and gonadotrophs $(19,29)$. Interestingly, if instead corticotrophs were depleted gradually, then the progenitor pool was not activated (30), suggesting that the loss of signal from the end organ may be required for PSCs mobilization (29). During pregnancy, the number and activity of lactotrophs rise in an expansion partly driven by estrogen (31) and indeed treatment of male mice with oestradiol causes a sharp rise in Sox $2^{+}$ PSC proliferation, a finding also observed in experimental gonadodectomy (19). The heightened activity of PSCs during the neonatal expansion of the gland and production of new endocrine cells is also clear, and they show increased proliferation as well as multipotent differentiation capacity (91). The potential involvement of PSCs in the subtler changes to the gland that occur during puberty and sexual maturation is logical, but as of yet unproven.

\section{Stem Cells and Regenerative Medicine in the Pituitary Gland}

Recent advances in the in vitro recapitulation of pituitary development highlight the potential of cell-based therapies to revolutionize the treatment of hypopituitarism, which is defined by the failure to secrete one or more pituitary hormones, and typically requires lifelong hormone replacement therapy. Pioneering work by Suga et al. reported the induction of self-organizing RP-like structures from mouse ES-cells, which contained corticotrophs and somatotrophs and were capable of rescuing systemic glucocorticoid level in hypopituitary mice (92). Mimicking pituitary development, their protocol involves the induction of adjacent layers of non-neural head ectoderm and hypothalamic neuroectoderm, which a follow up study showed was also applicable to human embryonic stem cells (ESCs) (93). Using an alternative approach, Dincer et al. were able to induce a placodal fate in adherent hESCs cultures, ultimately producing functional corticotrophs, that secreted ACTH after subcutaneous implantation in mice (94). Preliminary attempts at generating pituitary organoids from adult mouse PSCs have been performed, though to date, these have lacked the degree of self-organization, and functional hormone release achieved by their ESCsderived counterparts (95). Interestingly, in all strategies ACTHsecreting cells are the predominant differentiated endocrine cell type produced. Future work will likely focus on the targeted generation of other hormone secreting cells, and move 


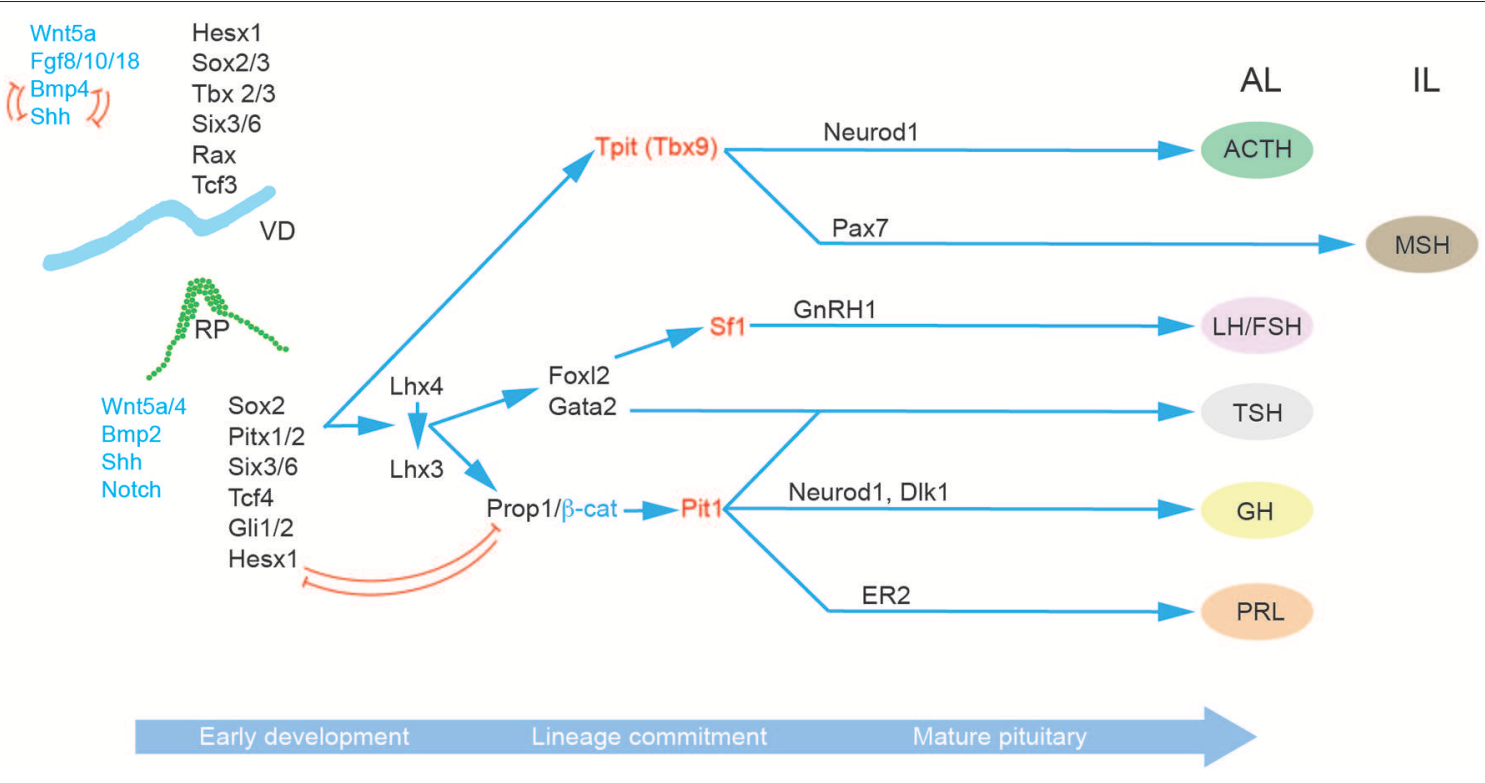

FIGURE 2 | Molecular regulation of pituitary gland development. A succession of transcription factors (black) and signaling molecules (blue) determine the establishment of RP and the subsequent lineage specification and differentiation in the progenitor cells of the developing pituitary hormone-secreting cell types characteristic of the mature anterior pituitary gland: corticotrophs (ACTH), gonadotrophs (FSH and LH), thyrotrophs (TSH), somatotrophs (GH), and lactotrophs (PRL), The key lineage commitment makers are highlighted in red. Arrows indicate upstream relationships in molecular signaling pathways, not necessarily direct activation. Red T-bar arrows denote repressive relationships. Abbreviations: ACTH, adrenocorticotropic hormone; AL, anterior lobe; FSH, follicle-stimulating hormone; GH, growth hormone; IL, intermediate lobe; LH, luteinizing hormone; MZ, marginal zone; PL, posterior lobe; PRL, prolactin; RP, Rathke's pouch, VD; Ventral diencephalon.

toward orthotopic transplants to investigate the degree to which transplanted cells can integrate into the regulatory circuitry governing physiological hormone secretion.

\section{ADRENAL CORTEX}

\section{Endocrine Function and Key Pathways Guiding Adrenal Cortex Development}

The adrenal cortex is essential for life. It is the primary site of steroid synthesis, producing glucocorticoids under the control of the HPA and mineralocorticoids under the control of the renin-angiotensin-aldosterone system (RAAS). Glucocorticoids regulate glucose metabolism, inflammation, immune responses, muscle and skeletal mass as well as cognition, well-being and memory, while mineralocorticoids control extracellular fluid volume and sodium homeostasis, and hence have an important influence on blood pressure.

The adrenal cortex originates from a group of cells within the dorsal coelomic epithelium at $\sim \mathrm{e} 9.0$ in mice and 34 weeks in humans (Figure 3). These cells form the socalled adrenogonadal primordium (agp) and express the master regulator of adrenocortical differentiation and function, namely Steroidogenic factor-1 (Sf1, encoded by Nuclear Receptor Subfamily 5 Group A Member 1 -Nr5a1) (96). Sf1 ${ }^{+}$cells delaminate from the coelomic epithelium and invade the overlying mesonephric mesenchyme. The agp then separates forming the adrenal anlagen migrating dorsomedially and the gonadal anlagen, which settles dorsolaterally. Genetic and molecular evidence have demonstrated that the transcription cofactor Cbp/P300-Interacting Transactivator 2 (Cited2) interacts with the transcription factor Wilms Tumor 1 (Wt1) to stimulate expression of Sf1 in the agp prior to the separation between gonadal and adrenal primordia (97). The adrenal primordium is then invaded by migratory neural crest- and Schwann cell precursors-derived cells that will form the neuroendocrine medulla (see section on adrenal medulla). Subsequently the gland becomes encapsulated by mesenchymal cells. The cortex is composed of fetal adrenal cells that are established before the outer definitive adrenal population emerges between the capsule and fetal adrenal. Functional zonation is completed around birth. A crucial lineage relationship between fetal adrenal cells and adrenal capsular cells to the differentiated adrenal cortex was determined using specific Cre lines permitting the identification of cells that have at some time actively expressed $N r 5 a 1$ under control of the fetal adrenocortical-specific enhancer (FAdE), an essential element in driving and maintaining Sf1 expression in the fetal cortex. These experiments indicated that a subset of capsular cells are indeed descendants of fetal adrenocortical cells that once expressed $\mathrm{Nr} 5 \mathrm{a} 1$ (98).

\section{Stem Cells and Self-Renewal in the Adrenal Cortex}

The adrenal cortex undergoes a self-renewal process and important paracrine effectors supporting a dynamic centripetal streaming of adrenocortical cells have been identified with the use of specific mouse transgenic models (99). Adrenocortical selfrenewal in the experimental animal relies on the differentiation 


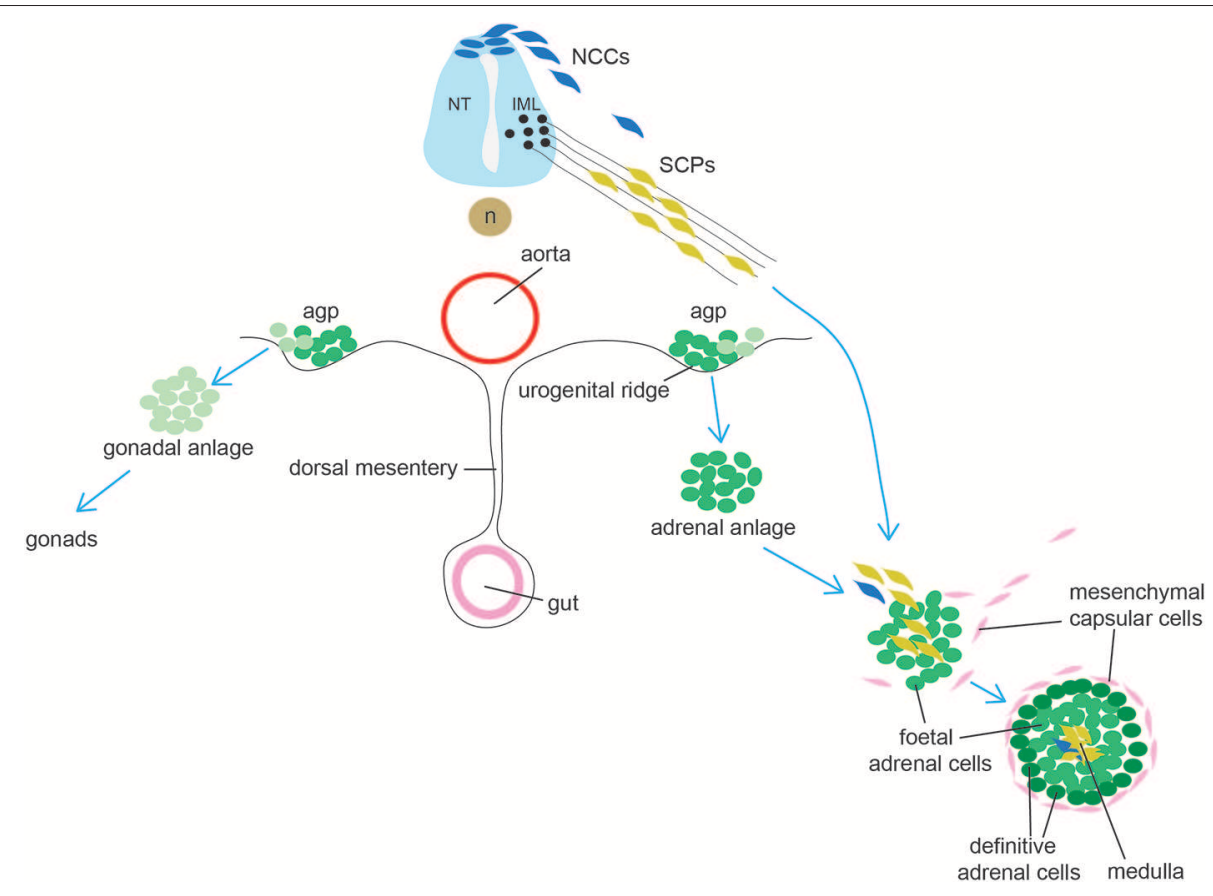

FIGURE 3 | Schematic representation of adrenal gland development. Cells from the adrenogonadal primordium (agp) form the adrenal and gonadal anlage. The adrenal anlage is invaded by migrating medullary progenitors who derive from early migrating neural crest-derived cells (NCCs, a minority in mice) and from late migrating Schwann cell precursors (SCPs). Concomitantly, the adrenal is encapsulated by mesenchymal cells. During late embryogenesis, definitive adrenal cells appears and will substitute fetal adrenal cells. IML: intermediolateral column (IML); NT, neural tube; n, notochord.

of at least two cell populations of progenitor cells, located in capsular and subcapsular compartments (Figure 4). It was shown that $\mathrm{Shh}$ is expressed in $\mathrm{Sf}^{+}$but relatively undifferentiated cortical cells in the subcapsular region of the mouse (100, 101) and rat (102) adrenal starting from e12.5 and e13.5, respectively. Capsule cells transduce the Shh signal, and lineagetracing studies have shown that $\mathrm{Glil}^{+}$capsular cells delaminate into the cortex, lose their responsiveness to Shh, and become $\mathrm{Shh}^{+} / \mathrm{Sfl}^{+}$progenitor cells; they then proceed to become fully mature steroidogenic cells forming the distinct histological and functional layers: zona glomerulosa (ZG, secreting aldosterone and expressing aldosterone synthase, encoded by Cyp11b2) and zona fasciculata (ZF, secreting glucocorticoids, expressing $11 \beta$ hydroxylase, encoded by Cyp11b1) (100). Capsular Gli1 ${ }^{+}$ cells and subcapsular $\mathrm{Shh}^{+}$cells are therefore two interconnected types of adrenocortical progenitor cells; recently however it has been shown that the relative impact of capsular and subcapsular progenitor cells in generating new steroidogenic cells is extremely unbalanced post-natally with cortical Shh progenitor cells being preponderant in generating steroidogenic cells compared to the capsular Gli1 population (103).

Another player in the gland self-renewal is paternally expressed Dlk1/Preadipocyte Factor-1 (Pref1), a cleavable single-pass transmembrane protein and a member of the Notch/Delta/Serrate family. A number of experimental evidence suggest that Dlk1 may be involved in adrenocortical differentiation: (i) Dlk1 is expressed in $\mathrm{Shh}^{+} / \mathrm{Sf}^{+}$progenitor cells in rat adrenals (104), (ii) Dlk1 regulates Gli1 levels in H295R cells, possibly through the secreted ectodomain Dlk1 and in a $\beta 1$-integrin dependent fashion (104), (iii) its expression was found to be inversely correlated to the differentiation status of the ZG following remodeling of RAAS rats (104), (iv) its potential cross-talk with subcapsular Fgf signaling, as Fgfr2IIIb knock-out mice showed hypertrophic capsule and absence of capsular Dlk1 expression (105), and (v) its rapid disappearance after adrenal enucleation in rats and reappearance once zonation is restored (106). These data suggest that Dlk1 might be a negative regulator of adrenocortical differentiation, similarly to its wellestablished role in inhibiting adipogenesis (107). Interestingly, while Dlk1 is expressed in the subcapsular region of rat (104) and human (108) adrenals, it is mostly expressed in capsular cells in mice $(105,109)$. It is not currently known whether Dlk1 is co-expressed with $\mathrm{Glil}^{+}$progenitor cells in the capsule, or whether Dlk1 and Gli1 mark two different populations.

The lineage relationship between fully differentiated ZG and ZF cells during post-natal life and during regeneration was established with the development of a specific mouse model where Cre recombinase was targeted to the Cyp11b2 genomic locus (110). Genetic lineage tracing with these mice demonstrated that ZG cells can lineage convert to ZF cells in a Sf1 dependent manner, and these cells can mark the whole ZF in a period of 12 weeks, suggesting a relatively slow self-renewing process in the mouse adrenal cortex. However, as Cyp11b2 knock-out mice are still able to generate ZF cells, alternative and/or facultative cell sources active in sustaining ZF self-renewal (and therefore crucial in preserving homeostatic cortisol levels) 


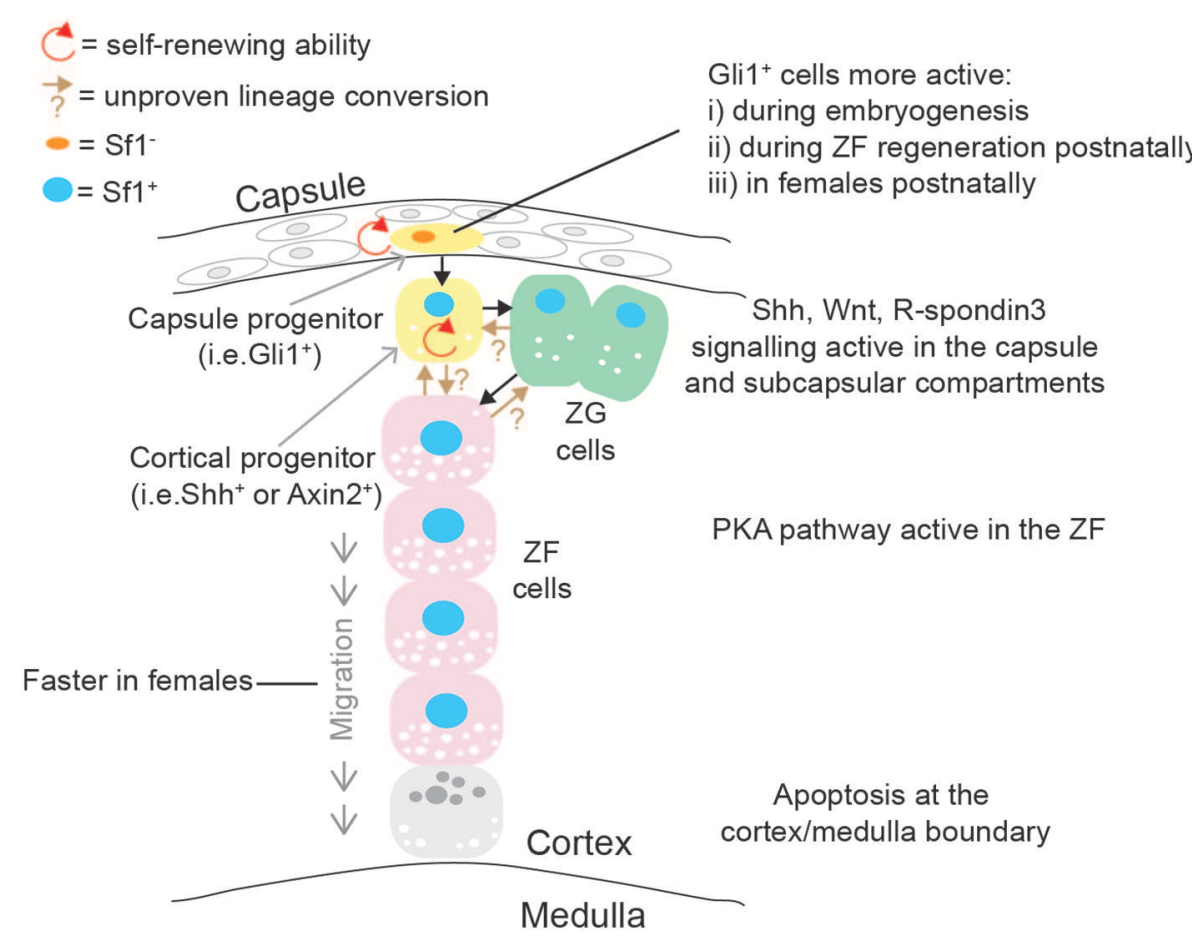

FIGURE 4 | Schematic representation of post-natal adrenal cortex centripetal streaming and self-renewal in mice. Gli1 ${ }^{+}$cells in the capsule can give rise to $\mathrm{Sf1}^{+} / \mathrm{Shh}^{+}$cortical cells: both are self-renewing adrenocortical progenitor cell populations. Shh ${ }^{+}$cells can become ZG cells, and ZG cells can lineage convert to ZF cells, which migrate centripetally. Direct differentiation between $\mathrm{Shh}^{+}$cells and ZF is probably occurring in parallel. These differentiation events are governed by pathways mostly active in the capsular/subcapsular region, while apoptotic figures are observed at the cortex/medulla boundary in senescence cells.

must be present, one example of such could be a subset of capsular/subcapsular progenitors able to directly differentiate toward a ZF identity.

Compelling evidence of the importance of other pathways in adrenocortical growth, self-renewal and zonation, has also been provided; for example, targeted disruption of $\beta$-catenin in $\mathrm{Sf}^{+}$cells resulted in an impairment of adrenal cortex development and maintenance in mice; this phenotype was even more pronounced when a Cre transgene was expressed at high levels, resulting in adrenal aplasia (111). Conversely, constitutive $\beta$-catenin activation induced ZG adrenal hyperplasia which ultimately led to adrenal cancer development in mice (112). Wnt-responsive cells were found to be $\mathrm{Shh}^{+}$progenitor cells as well as differentiated, steroidogenic cells of the ZG, but not the ZF, and rarely cells that were actively proliferating. In vitro experiments also demonstrated that stimulation of $\beta$-catenin signaling caused decreased corticosterone release; this was corroborated by not only a reduced expression of steroidogenic genes such as Cyp11a1, Cyp11b1, Star, and Mc2r, but also by a diminished Sf1 expression and Sf1 occupancy on steroidogenic promoters. Interestingly, Coiled-Coil Domain Containing 80 (Ccdc80) was found to be a novel $\beta$-cateninregulated gene in adrenocortical cells, and secreted Ccdc 80 could partially phenocopy suppression of steroidogenesis induced by $\beta$ catenin, in a Sf1-independent fashion (113). Wnt4 is key activator of the pathway in the cortex and knock-out experiments in mice demonstrated that capsular R-spondin3, a secreted protein and a known positive regulator of $\mathrm{Wnt} / \beta$-catenin pathway, induces Wnt4 and Shh expression within steroidogenic cells in the subcapsular compartment (114) and that its action is strongly antagonized by protein kinase A (PKA) activation, resulting in inhibition of ZG differentiation. PKA stimulation was able to increase inactivating and decrease activating $\beta$-catenin phosphorylation in adrenocortical cells in vivo. Therefore, it was suggested that PKA activation in the ZF is a key driver of Wnt inhibition and lineage conversion of cells to a ZG identity. The same authors provided evidence that constitutive PKA activation was able to inhibit $\beta$-catenin-induced ZG adrenal hyperplasia and subsequent tumorigenesis in vivo (115). Constitutive PKA activation, which was achieved by genetic deletion of the critical component Protein Kinase cAMP-Dependent Type I Regulatory Subunit Alpha (Prkarla) was also found to be crucial for conversion of ZF cell to a zona reticularis (ZR)-like phenotype, seemingly via lineage conversion of the innermost $\mathrm{ZF}$ cells; interestingly this process was found to be sexually dimorphic as testicular androgens were shown to increase adrenocortical Wnt signaling (antagonizing PKA), leading to slower adrenocortical cell turnover and delayed ZR appearance whereas gonadectomy sensitized males to hypercorticism and ZG-like formation (116). More recently, a thorough study of adrenocortical self-renewal in mice shed more light on this sexually dimorphic phenomenon: genetic lineage tracing was achieved using Axin2 mouse model; 
Axin2 has been shown to reliably act as a readout for Wntresponsive cells, and, as such, it is a frequently-used marker of functional stem cells. By comparing male and female mice, they found that female mice had significantly higher proliferation as well as turnover than males; moreover, in females but not males, the capsule $\mathrm{Gli1}^{+}$population was found to be more active in generating new steroidogenic cells post-natally. Interestingly, proliferation rates, cortex turn-over and recruitment of capsular $\mathrm{Gli1}^{+}$cells was enhanced in males following orchiectomy, suggesting that androgens might inhibit full recruitment of some adrenal cortex stem cell compartments; this was further corroborated by showing inhibition of $\mathrm{Gli1}^{+}$cells activation in ovariectomised females treated with dihydrotestosterone. This data is important as it might explain the biology behind the higher incidence of adrenal diseases in females (117).

Important factors involved in adrenal cortex differentiation and self-renewal under physiological conditions have also been discovered by assessing mutation and changes in gene expression in adrenocortical tumors. Two examples are the histone methyltransferase Enhancer of Zeste Homolog 2 (Ezh2), the most deregulated epigenetic factor in adrenocortical carcinomas (118) and the transmembrane E3 ubiquitin ligase zinc and ring finger 3 (Znrf3), a known Wnt inhibitor which is frequently inactivated in adrenocortical carcinomas (119). Ezh2 was found to be an important epigenetic factor ensuring the unidirectionality of differentiation events from ZG to ZF. Targeted inactivation of Ezh2 in mouse adrenal cells was achieved through the use of a Sf1Cre line crossed to a floxed Ezh2 allele; these mice had hypoplastic adrenal glands and developed primary glucocorticoid insufficiency (low corticosterone, high $\mathrm{ACTH}$, normal aldosterone in female mice) with blunted ZF differentiation (decreased Cyp11b1 mRNA expression), suggesting that Ezh2 is a key regulator of ZF differentiation and identity. This suggestion was proved by further experimental data showing that Ezh2 not only programmed adrenocortical cells to respond to ACTH via PKA signaling, but also inhibited accumulation of capsular/pericapsular $\mathrm{Gli1}^{+}$and Wt1/Gata4 ${ }^{+}$ spindle-like pericapsular cells. Interestingly, these $\mathrm{Gli1}^{+}$and Wt1/Gata ${ }^{+}$fibroblastic-like cells, commonly seen in aged or gonadectomised mice of specific backgrounds, were found to be derived from steroidogenic $\left(\mathrm{Sfl}^{+}\right)$cells through a mechanism involving dedifferentiation, rather than direct amplification of capsular cell populations (120).

Znrf3 was found to be expressed in both ZG and ZF cells in mice; adrenocortical-specific loss of Znrf3, achieved through the use of both Sf1Cre and Cyp11b2Cre lines crossed to a floxed Znrf3 allele, developed adrenal hyperplasia in the ZF in a ACTH-independent manner with loss of normal adrenocortical architecture; this phenomenon was found to be dependent on Wnt signaling as genetic inactivation of Znrf3 together with Porcupine (a key enzyme required for Wnt ligands maturation and activity) displayed normal adrenal cortex architecture and reduced ZF hyperplasia. The authors also found that Wnt4, normally highly expressed in the ZG with a decreasing gradient into the outer ZF, lost this characteristic expression pattern and instead displayed moderate-level expression throughout the entire ZF. Interestingly, this pattern was also altered for $\beta$-catenin protein expression, as well as Axin2 mRNA, strongly suggesting that loss of Znrf3 leads to increased Wnt/ $\beta$-catenin in the ZF promoting hyperplasia (121).

\section{Stem Cells and Regenerative Medicine in the Adrenal Cortex}

There is an undeniable case for stem cell regeneration therapy in adrenal insufficiency, however it is still in its infancy. Initial experiments showed the ability to obtain a steroidogenic lineage when Sf1 was forced-expressed in hESCs (122). Since then, others have reported the conversion of mouse and human ESCs, mesenchymal stem cells and inducible pluripotent stem cells (IPSCs) into adrenocortical-like cells, all by over-expressing Sf1 [reviewed in (123)].

Our laboratory has devised a technology for the generation of steroidogenic-like cells via reprogramming of skin-, bloodand urine-derived cells in humans. Reprogramming was achieved via forced expression of Sf1 through lentiviral delivery, together with the activation of the protein kinase A (PKA) pathway and in the presence of luteinising hormone releasing hormone (LHRH). These reprogrammed cells had ultrastructural features resembling steroid-secreting cells, expressed steroidogenic enzymes and secreted steroid hormones in response to physiological and pharmacological stimuli. They were viable when transplanted into the mouse kidney capsule and intra-adrenal. Importantly, the hypocortisolism observed in cells derived from patients with adrenal insufficiency due to congenital adrenal hyperplasia was rescued by expressing the wild-type version of the defective disease-causing enzymes. This study provided for the first time an effective tool with many potential applications to study adrenal biology and pathobiology in a personalized manner and opened up avenues for the development of precision therapies (124). The main obstacle to a clinical application of the strategies described above is the absence of a protocol which allows derivation of (i) proper adrenocortical-like cells from pluripotent stem cells or somatic cells without overexpression of Sf1, and (ii) a cell population able to self-renew similarly to the cortex.

\section{ADRENAL MEDULLA}

\section{Endocrine Function of the Adrenal Medulla}

The adrenal medulla is the inner part of the adrenal gland and is mainly responsible for the synthesis and secretion of catecholamines, such as epinephrine (adrenaline) and norepinephrine (noradrenaline), both derived from the aminoacidic tyrosine and stored in vesicles prior to secretion. The main cell type of the adrenal medulla is the chromaffin cell (or pheochromocytes), named as such because of the affinity of catecholamines for chromium salts. The adrenal medulla is highly innervated by preganglionic sympathetic fibers. Epinephrine and norepinephrine are responsible for the execution of the fight-or-flight response of the sympathetic nervous system; such response involves (i) an increase in blood pressure via binding and activation of $\alpha 1$ receptors on vascular smooth muscle cells (resulting in vasoconstriction and increased blood flow to muscles and brain); (ii) an increase in the heart 
rate and contractility, (iii) a relaxation of smooth muscles in the airways (via $\beta 2$-adrenoreceptors, to increase breathing), (iv) an increase in glycaemia via activation of the glycogenolysis pathway concomitant to stimulation of glucagon secretion via $\beta 2$ receptors and decreasing of insulin secretion via $\alpha 2$ receptors in the Islets of Langerhans.

\section{Key Pathways Guiding Adrenal Medulla Development}

Until very recently, chromaffin cells were thought to be direct derivates of neural crest, with a stream of neural crest-derived cells migrating and committing to a common sympathoadrenal lineage ending up in the vicinity of the dorsal aorta, where they would proliferate and continue migrating either ventrally (cells forming the adrenal medulla) or dorsally (cells forming the sympathetic ganglion) (125, 126). In 2017 Furlan et al., using genetic lineage tracing approaches and genetic ablation, convincingly showed that the majority of chromaffin cells derive from a specific cell type, termed Schwann Cell Precursor (SCP) (127) (Figure 3). SCPs are the earliest well-defined glial-like cell population during peripheral nervous system development (the radial glial being their corresponding identifiable precursor in the central nervous system) and known multipotent stem cells which can differentiate and generate different cell types, such as the parasympathetic nervous system $(128,129)$. SCPs themselves are a neural crest derivates which have undergone an extensive change in gene expression with many glial-associates genes (which are also expressed in Schwann cells) being activated. SCPs appear in mouse at $\sim \mathrm{e} 12.5$; later in development, they are also able to generate the so-called immature Schwann cells, which differentiate to form Myelin- and Remak- (non-Myelin) Schwann cells. SCPs have an intimate association with neurons and their processes and are extremely dependent on axonal signals for both migration, survival and differentiation, a feature that is not shared by neural crest cells, which migrate more freely. Over time, it has become clear that SCPs could generate direct derivates which were of a different lineage to Schwann cells, such as endoneurial fibroblasts (130), parasympathetic ganglia (128, 129), melanocytes (131), and mesenchymal cells giving rise to odontoblasts and tooth pulp cells (132). Furlan et al. traced SCPs using neural crest and glial-specific inducible Cre lines [Sox10 and the myelin component Proteolipid Protein 1 (Plp1)]. Injection of tamoxifen at e11.5 followed by analysis at e17.5 showed that at least half of chromaffin cells in the adrenal medulla derived from SCPs. The contribution of nerveassociated SCPs was further corroborated by genetic ablation of SCPs with diphtheria toxin subunit A, resulting in a significant depletion of chromaffin cells which were able to migrate to the adrenal medulla. Moreover, the dependency of adrenal medulla formation on SCPs migration along nerves was elegantly demonstrated by achieving specific ablation of preganglionic motor neurons, resulting again in a strong (78\%) reduction of chromaffin cells, with the remaining chromaffin cells presumably derived from earlier neural crest migrating cells. Another key finding from this study is the demonstration of an early lineage segregation of sympathoblasts and chromaffin cells, which were until recently considered to originate from a common sympathoadrenal progenitor $(133,134)$.

\section{Stem Cells and Regenerative Medicine in the Adrenal Medulla}

The question of whether stem/progenitor cells with regenerating abilities persist in the post-natal adrenal medulla has not been extensively investigated. Initial in vitro studies showed that cells with progenitor characteristics could be enriched from bovine (135) and human (136) medullary extracts; these cells could also generate spheres expressing progenitor cell markers such as Nestin (a type IV intermediate filament protein expressed in multipotent neural stem cells), CD133, and Notch1. Subsequently, by using a Nestin-GFP transgenic mouse model, it was shown that Nestin $^{+}$cells (accounting $6 \%$ of medullary cells) were negative for both Tyrosinehydroxylase and chromogranin A (two markers of differentiated chromaffin cells), suggesting that Nestin was not expressed by mature chromaffin cells. Isolated Nestin-GFP cells were also able to generate spheres, which were able to differentiate into chromaffin cells and neurons. This was also confirmed in vivo where mice were subjected to repeated immobilization stress; again, the progeny of $\mathrm{Nestin}^{+}$cells, investigated using an inducible nestin-Cre mouse line, was found to include cells with glial, neuronal, and chromaffin identity (137). Chromaffin-like cells have been recently derived from hESCs via a multistep protocol involving first differentiation toward neuroectoderm-like caudal neural progenitors via TGF $\beta$ and GSK3 $\beta$ inhibition followed by establishment of neural crest stem/progenitor cells neurospheres in the presence of Fgf2 and Bmp2. Further treatment of these neurospheres with Bmp4 or with dexamethasone plus phorbol 12-myristate 13acetate (PMA) induced a strong up-regulation of markers of mature chromaffin cells, such as tyrosine hydroxylase and Phenylethanolamine N-methyltransferase (138). The generation and culture of functional chromaffin-like cells could be employed in the field of regenerative medicine, specifically in cases of neuroendocrine/neurodegenerative diseases, and also for pain management.

\section{THYROID GLAND}

\section{Endocrine Function in the Thyroid Gland}

The thyroid is a butterfly-shaped gland located in front of the trachea. Its main function is to regulate body metabolism by producing thyroid hormones T4 and T3 from iodine. Thyroid tissue is composed by two cell types: follicular cells, responsible of thyroid hormones secretion, and parafollicular cells (or C cells), which secrete the hormone calcitonin, involved in calcium regulation. The thyroid gland is controlled by the pituitary gland through secretion of TSH which stimulates the thyroid gland to produce more hormones.

\section{Key Pathways Guiding Thyroid Gland Development}

Follicular cells arise from the thyroid anlage, a group of foregut endodermal cells located on the midline of the posterior 


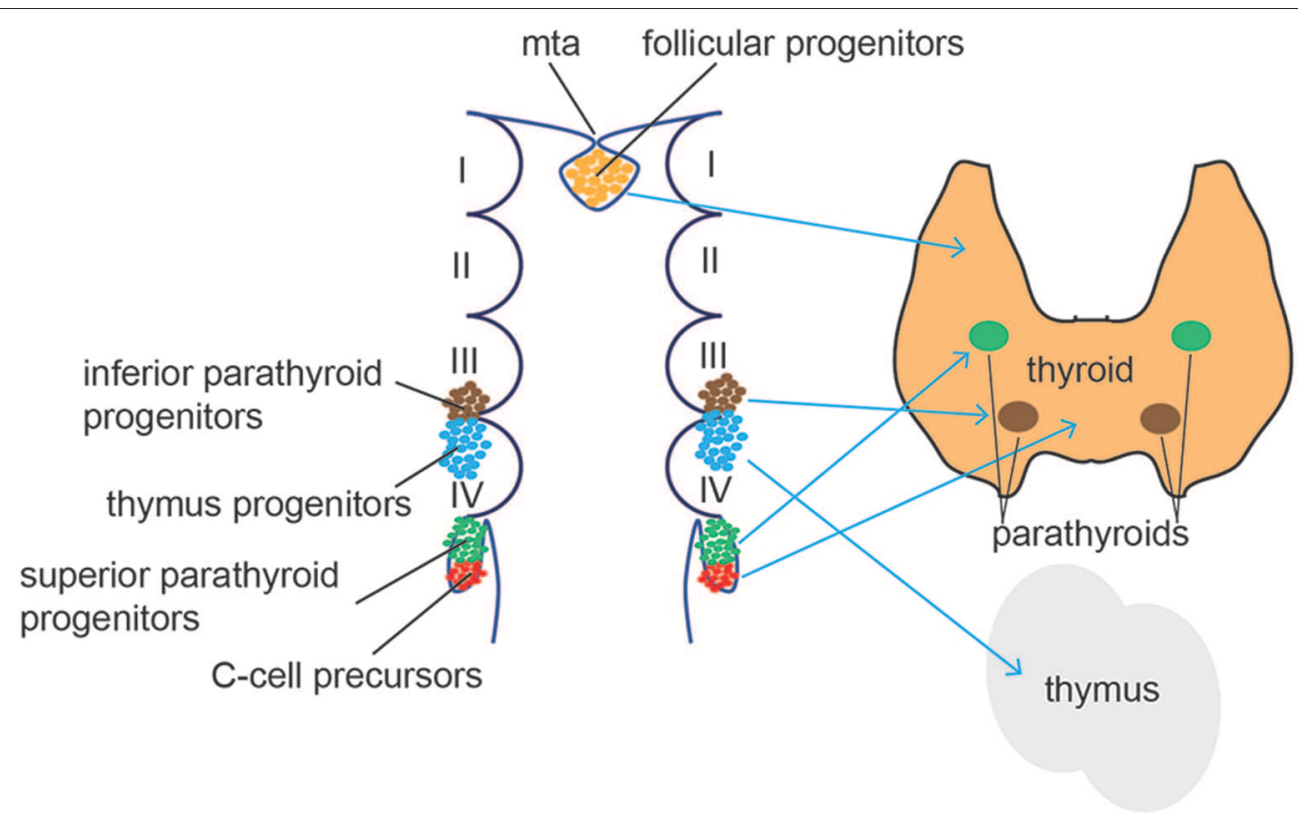

FIGURE 5 | Thyroid/Parathyroid development. Follicular thyroid progenitor cells (orange) derive from the midline thyroid anlage (mta), an endodermal tissue in the floor of the pharynx just caudal to the 1st pharyngeal arch. The superior parathyroid glands (green) originate from the 4th brachial pouch while the inferior parathyroid (blue) and the thymus develop from the 3rd brachial pouch. C cells (red) differentiate from the ultimobrachial body, below the 4th brachial pouch.

mouth cavity, while parafollicular cells differentiate from the ultimobranchial bodies, a structure derived from the fourth pharyngeal pouch in the developing neck (Figure 5). Recent reports demonstrate that parafollicular C cells develop from pharyngeal endoderm and not neural crest cells, as previously suggested $(139,140)$. Using a dual mouse lineage tracing strategy, Johansson and collaborators provided direct evidence that $\mathrm{C}$ cells derive from Sox17-expressing endodermal progenitors and not from Wnt1-expressing neural crest-derived progenitor cells (141). Both cell types migrate from their original sites to form the definitive thyroid gland $(142,143)$. During this process, thyroid anlage cells bud by proliferation and invade the surrounding mesenchyme. The thyroid primordium bifurcates bilaterally and migrates toward the larynx and proximal trachea, a process accompanied by intense thyroid progenitor proliferation. Once the left and right thyroid lobes are formed, functional cellular differentiation takes place, which in humans occur after the eleventh week of gestation (144).

During early specification of thyroid cells, exclusive cooperation of the transcription factors HaematopoieticallyExpressed Homeobox Protein (Hhex), NK2 Homeobox 1 (Nkx2-1, also known as thyroid transcription factor, Ttf1), Pax8 and Forkhead Box E1 (Foxe1, also known as thyroid transcription factor 2, Ttf2) have been shown to be essential $(145,146)$. Indeed, genetic deletion of these transcription factors individually resulted in severe thyroid hypoplasia or lack of thyroid formation (147-151). Hhex plays a role in maintaining total progenitor cell numbers in the budding epithelium, while it is not required for thyroid precursor specification (145). Nkx2-1 is not essential for initial specification of the thyroid gland, but is required for the development and morphogenesis. $\mathrm{Nkx2-1^{-/- }}$ mice develops a thyroid rudiment which degenerates through apoptosis (152), highlighting its primordial role in pharyngeal endoderm-derived tissues. Pax8 acts as a regulator of thyroid precursor survival. Similar to $\mathrm{Nkx} 2-1^{-/-}$mice, $\mathrm{Pax} 8^{-/-}$animals show a progressive degeneration of thyroidal primordium (145). Finally, Foxe1 plays a role in migration of thyroid precursor cells. Although the thyroid primordium is formed, progenitor cells in Foxe1-null animals remain attached to the pharyngeal floor whereas in wild-type embryos they are detached from the pharynx cavity and begin to migrate (149). Altogether, the coordinated expression and regulation of these key transcription factors in a timely manner drives the generation, expansion and migration of progenitor cells to form the definitive thyroid tissue.

\section{Stem Cells and Self-Renewal in the Thyroid Gland}

The first indirect evidence that the thyroid gland was an organ endowed with extremely slow self-renewal potential was provided in 1974 through observation of follicular cell proliferation (153). Subsequently, cell population kinetics was studied in vivo in dog thyroids via bromodeoxyuridine incorporation and in vitro in human thyroid slices, suggesting a complete turnover of $\sim 8.5-14.4$ years (154). These and other studies in the 1980s led to the hypothesis of the existence of an unknown number of resident adult stem cells in the thyroid governing this slow self-renewal process (155). Initial efforts to isolate thyroid stem cells in mice showed the existence of a small pool of cells expressing the stem cell markers Oct4, nucleostemin and the ATP binding cassette (ABC)-dependent 
transporter ABCG2 (the latter endowing cells with the ability to efflux the vital dye Hoechst 33342, also referred to as side population), while expressing low levels of differentiated thyroid markers such as thyroglobulin, TSH receptor, thyroid peroxidase, Pax8, or thyroid transcription factor 1 (Titf1). The same authors also demonstrated that ABCG2-expressing cells were located in the interfollicular space of the thyroid gland but not in cells lining the follicles (156).

In humans, another evidence of the existence of thyroid stem cells were reported by Thomas et al. (157); histologic staining and cultured cells derived from goiters (abnormal enlargement of the thyroid gland), showed a subset of cells expressing the stem cell marker Oct4, and the early endodermal markers Gata4 and Hepatocyte Nuclear Factor $4 \alpha$ (HNF4 $\alpha$ ) markers while they were negative for the differentiated cell marker thyroglobulin. Interestingly, these markers were found not to be expressed in the differentiated rat thyroid cell line FRTL5 cell line, while they were expressed in undifferentiated thyroid carcinoma cell lines.

Lan et al. isolated adult thyroid stem cells as side population from human goiters by employing Hoechst 33342 staining (expression of ABCG2) followed by fluorescence-activated cell sorting (FACS). Those cells, which accounted for $0.1 \%$ of the total cell population, showed stem cell morphological characteristics (smaller in size and higher nucleus to cytoplasm ratio compared with differentiated cells) and expression profiles compatible with an undifferentiated population, and were able to differentiate in vitro into thyroid cells upon TSH treatment. Interestingly, spheres established from dissociated thyroids were able to grow in vitro in a medium enriched with Egf and bFgf but without TSH, and contained a 50fold enrichment of side population cells. When stem cells isolated from these 3D structure (named thyrospheres) were grown as monolayer or embedded in collagen, differentiation under the influence of TSH was observed (expression of Pax8, TG, NIS, TSHr, and TPO as well as 125 iodide uptake in response to TSH). These data proved the ability of adult human goiters-derived thyrospheres to differentiate into functional thyroid cells (158). In 2008, Fierabracci and collaborators generated spheroids in culture from human healthy thyroids; their thyrospheres could self-replicate in vitro and generate thyroid hormones upon differentiation conditions (159).

Fgfs and Bmps are essential signaling pathways for thyroid cell fate induction. Revest and collaborators reported lack of thyroid glands in Fgfr2b-deficient mice (160). The same phenotype was reported on Fgf10 knockout mice (161), suggesting that Fgf10 could act as a Fgfr2b ligand during thyroid development. Other Fgfs, like Fgf2 and Fgf8, have been involved in thyroid development (162). In vitro studies using mouse embryonic stem cells supports the evidence of FGF signaling in differentiating thyroid cells. Longmire and collaborators showed that Fgf2 and Bmp4 are required to generate functional thyroid cells from human and mouse ESCs/ iPSCs (163), reinforcing the notion that these signaling pathways are important during development of the thyroid glands.

\section{Stem Cells and Regenerative Medicine in the Thyroid Gland}

Studies in thyroid regeneration after partial thyroidectomy (PTx) showed that the central areas of both lobes act as the proliferative centers (164). Microarray analysis performed after PTx reveal increased expression of embryonic development pathways, suggesting potential dedifferentiation events or activation of resident stem/progenitor cells. Interestingly, levels of serum T4 hormone, which were decreased after PTx, recover to normal after a week. Accordingly, increases in TSH were detected after PTx to stimulate the gland to produce more T4. In fact, TSH is known to play a role in promoting undifferentiated progenitor/stem cells to transform into mature thyroid follicular cells $(158,165)$.

Zhang and collaborators have postulated a model for the origin of thyroid carcinoma from adult progenitor cells based on their cell of origin and the levels of differentiation (166), however the low turnover of thyroid gland cells make it difficult to study the relationship between normal and thyroid cancer stem cells.

Several groups have generated thyroid progenitor and mature functional thyroid cells from both mouse and human pluripotent stem cells $(163,165,167-169)$. Pioneering work by Arufe and collaborators showed the ability of mouse ES cells to differentiate toward thyroid follicular cells when cultured in serum-free medium supplemented with TSH (165). In 2012, evidence of in vivo functionality was demonstrated using mouse ES-derived three-dimensional thyroid follicular cells. Differentiated cells, obtained through transient overexpression of the transcription factors Nkx2-1 and Pax8, were able to restore thyroid hormone plasma levels once implanted into athyroid mice (170).

Modulation of Tgf $\beta$, Bmp and Fgf signaling pathways lead to the generation of primordial thyroid progenitor cells from mESCs (163), that could be further matured to functional, transgene-free thyroid follicular organoids able to secrete thyroid hormones and rescue hypothyroid mice after transplantation (168). Interestingly, iPSCs-derived human thyroid progenitor cells were obtained from healthy donors and patients with hypothyroidism (168). More recently, functional iPSCs-derived human thyroid follicular cells showed the ability to express thyroid proteins and secrete thyroxine in vitro (169).

\section{PARATHYROID GLANDS}

\section{Endocrine Function in the Parathyroid Glands}

The parathyroid glands are four small glands that produce and secrete parathyroid hormone (PTH) into the bloodstream. Located behind the thyroid gland, parathyroid glands control bodily calcium levels, playing a crucial role in regulating nervous and muscular systems, bone calcium release and calcium reabsorption in the kidney.

\section{Key Pathways Guiding Parathyroid Glands Development}

The parathyroids are endoderm-derived tissues that form from the third and fourth pharyngeal pouches in humans (171), 
before migrating to the ventral midline of the pharyngeal and upper thoracic region (Figure 5). Studies in mice demonstrated a common origin of parathyroid and thymus cells in early organogenesis. The parathyroid-thymus primordia separate around e12.5 in mice during the ventral migration, a process mediated by cell adhesion molecules and Bmp4 signaling $(172,173)$. Expression of the transcription factor glial cells missing $2(\mathrm{Gcm} 2)$ is essential for parathyroid specification. $\mathrm{Gcm} 2^{-/-}$mice lack parathyroid glands and develop primary hypoparathyroidism (174) and human Gcm2 mutations have been associated with dysregulated parathyroid hormonal levels $(175,176)$. Gcm 2 expression and patterning in the developing parathyroid gland is tightly controlled by Shh signaling (177, 178). Shh controls the expression of the transcription factors Tbx1 and Gata3 that, together with $\mathrm{Gcm} 2$, restrict the parathyroid cell fate of the third pharyngeal pouch (179). Indeed, $\mathrm{Shh}^{-1-}$ mice showed smaller, aparathyroid primordia, due to the inability to activate $\mathrm{Gcm} 2$ expression. Moreover, Shh was found to be active in both dorsal endoderm and the adjacent neuralcrest derived mesenchyme. Bain and collaborators showed evidence that Shh signals from both tissues promote parathyroid specification and organogenesis (180).

\section{Stem Cells in the Parathyroid Glands}

Resident adult stem cells in the parathyroids have been poorly characterized. Human parathyroid-derived stem cells (hPDSCs) were isolated from surgically removed parathyroid glands via enzymatic digestion (181). In vitro, selected clones of hPDSCs showed characteristic of adult stem cells as they: (i) could differentiate toward osteogenic, chondrogenic and adipogenic lineages using appropriate induction media, (ii) were positive for mesenchymal stem cell markers and negative for hematopoietic and endothelial markers, (iii) and showed telomerase activity and self-renewal capacity.

Hyperparathyroidism usually occurs due to clonal parathyroid hyperplasia or adenomas of the gland $(182,183)$. Parathyroid tissue from 20 patients with hyperparathyroidism showed clonal cellular expansion of resident stem cells in both malignant and benign parathyroid tumors, assessed by immunohistochemistry and FAC-sorting for the tumorigenic stem cell makers CD44/CD24 (184). The authors suggested the involvement of a population with stem cell markers in the development of parathyroid hyperplasia.

\section{Stem Cells and Regenerative Medicine in the Parathyroid Glands}

Differentiation of parathyroid-like cells from pluripotent stem cells has been achieved in vitro using mESCs. Bingham et al. reported the generation of parathyroid hormone (PTH)secreting cells expressing both intermediate endoderm progenitor markers (Cxcr4, Eya1, Six1, and Pax2) and parathyroid-specific markers (glial cell missing-2 [Gcm2], CCL21, calcium sensing receptor [CaSR], and PTH) (185).

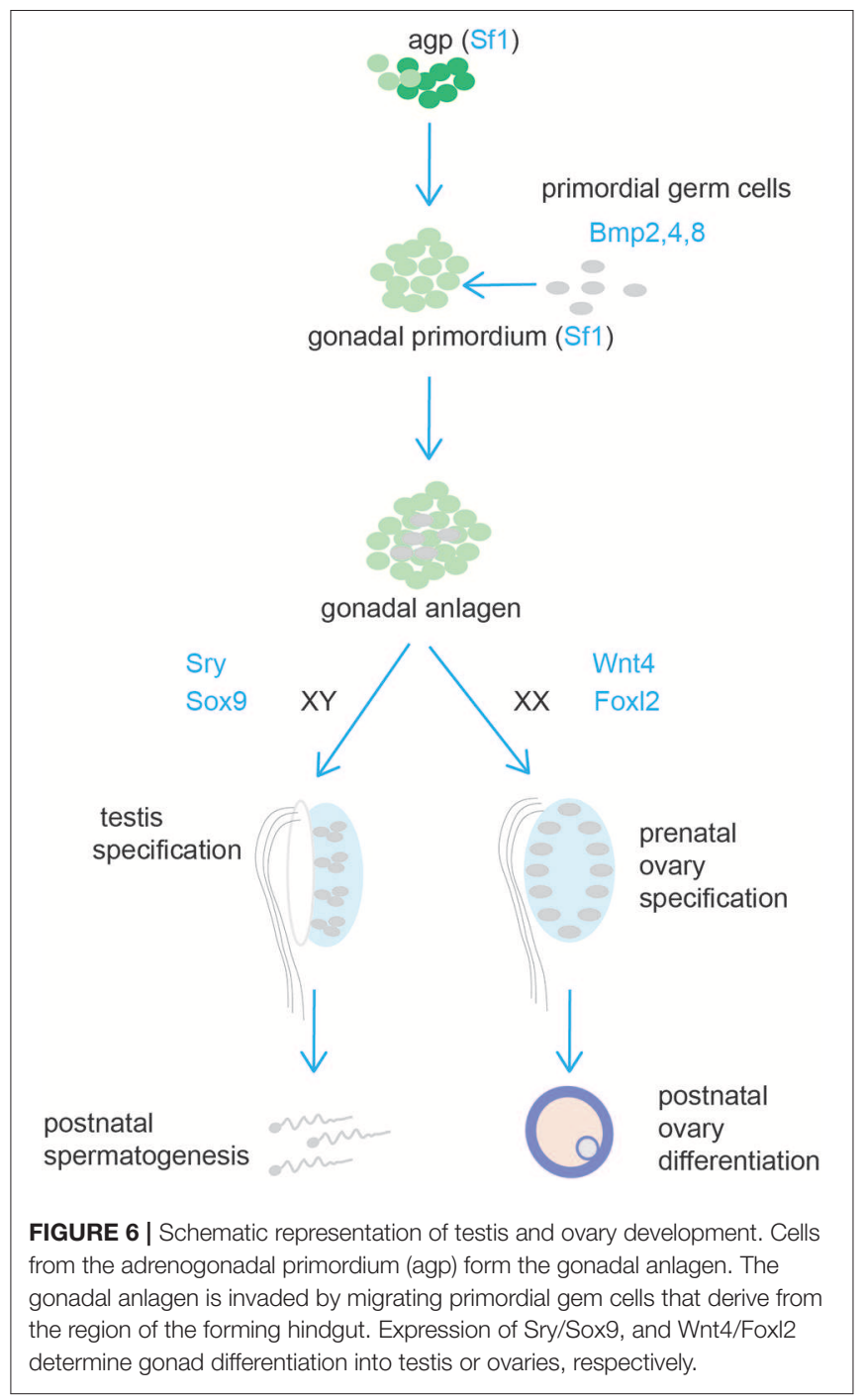

\section{GONADS}

\section{Shared Developmental Stages of the Gonads}

The gonads and the adrenal cortex originate from the agp (see above, adrenal cortex section). Gonadal primordia develop as paired thickenings of the coelomic epithelium known as the urogenital ridge (Figure 6). Initially, the mammalian gonads develop identically in both female and male embryos. The early mammalian gonad is in fact an undifferentiated primordium composed of bipotential precursor cells that can follow one of two possible fates to become either a testis or an ovary. In mice, development of the urogenital ridge starts at around e11 and continues until e11.5-12.0 when sexual differentiation begins. Primordial germ cells (PGCs) (the precursors of oocytes and spermatozoa in the ovaries and testes, respectively) do not arise within the ridge but migrate from an entirely separate source; at around e7, PGCs are seen in mice in the region of the forming hindgut. The appearance of PGCs is concomitant 
with increase in the activity of Bmp2, Bmp4, and Bmp8. Early studies showed that ablation of Bmp4 (186) and Bmp2 (187) in mouse embryo resulted in lack and severe reduction of PGCs number, respectively.

Between around e9.0 and e11.5, PGCs migrate to the genital ridge $(188,189)$. During migration and after settling in the gonad the PGCs divide mitotically, and their number increases rapidly. By e13.5 the genital ridge contains thousands PGCs from an initial population of 10-100 in mice (190).

\section{TESTIS}

\section{Key Pathways Guiding Testis Development}

In the male gonad, PGCs give rise to T1-prospermatogonia and enter G0 mitotic arrest, a state in which they remain until after birth (191). T1-prospermatogonia resume proliferation during the first week after birth when they become T2prospermatogonia and migrate to the seminiferous tubules' basement membrane. These cells give rise to the first round of spermatogenesis concomitant with the establishment of the initial pool of Spermatogonial Stem Cells (SSCs) that maintain spermatogenesis throughout post-pubertal life (192).

Differentiation of testis is marked by polarization of gonadal somatic Sertoli cells that form epithelial aggregates around germ cells. This process leads to the reorganization of the gonad into two compartments: the tubular testis cords (referred to as seminiferous tubules after birth), which consist of Sertoli cells and germ line cells, and the interstitial space between the cords, which contains Leydig cells (producing testosterone under the action of LH) and vasculature. Peritubular myoid cells surround Sertoli cells and deposit a basal lamina at the periphery of the tubular structures (193). Post-natally, Sertoli cells form tight junctions with each other that compartmentalize the seminiferous epithelium into basal and adluminal compartments.

In mammals, testis differentiation depends on gonadal expression of the Y-linked gene Sry, a transcription factor initiating Sertoli cell differentiation. By e11 in mice and 4144 days post-ovulation in humans, Sry is detected specifically in Sertoli cells (194). Its expression is restricted between e11 and e13 in mice, whilst it is maintained at low levels during gestation in humans. Interestingly, testis-cord formation occurs between e12.5 and e13, a little later than when Sry is detected. Differentiation of testis seems dependent on a critical threshold of Sry-expressing cells. About $10 \%$ of Sertoli cells were found not express Sry in testes of chimeric $\mathrm{XX} \leftrightarrow \mathrm{XY}$ embryos, while gonads composed of $<30 \%$ Sry-expressing cells developed as ovaries (195). Experiments with transgenic mice demonstrated that the early male marker Sox 9 is up-regulated by the transient expression of Sry specifically in Sertoli cell precursors (196). More recently, this was confirmed by the generation of a mouse antibody against Sry (197). Further studies revealed that Sry binds to multiple elements within Sox9 enhancer in mice and it does so along with Sf1 (198). The activation of a network of genes downstream of Sox9 then promotes male development while simultaneously blocking the genes that drive ovarian development [reviewed by (199)].
The fact the Sf1 is essential for gonadal development is widely accepted (200). During the early phase of proliferation (e11.5-12.0) Sertoli cells (and interstitial cells) derive from the division of cells expressing Sf1 of the coelomic epithelium. Sf1 is subsequently downregulated (or completely lost) in the coelomic epithelium and proliferation continue in $\mathrm{Sf}^{-}$cells at and below the coelomic epithelium to produce only interstitial cells (201).

The importance of Sry in testis development is highlighted by numerous mutations causing sexual-development disorders (202), yet little is known about its regulation. Nevertheless, three key transcription factors, Gata4, Friend of Gata protein 2 (Fog2) and Wt1, have been implicated in the transcriptional or posttranscriptional regulation of the gene [reviewed by (202)].

\section{Stem Cells and Self-Renewal in Testis}

Spermatogenesis, the process that throughout the life of males produces sperm, represents a typical example of a supported stem cell system. Spermatogenesis occurs in the seminiferous tubules where spermatogonia that reside on the basement membrane undergo self-renewal divisions and proliferate to form spermatogonial clusters. In rodents, three types of spermatogonia have been identified, namely Type A, intermediate and B. Type A cells are the most undifferentiated and have been classified by morphological analysis into Asingle (As, isolated cells), Apaired (Apr, chain of two connected cells), or Aaligned (Aal, chain of 4,8 or 16 or more cells), that remain connected by intercellular bridges due to incomplete cytokinesis (Figure 7). According to the prevailing theory in the field, known as the 'As model, spermatogonial stem cells (SSCs) are As cells (roughly 0.03\% of the total number of spermatogonia) that divide into two daughter Apr spermatogonia which further divide into Aal spermatogonia $(203,204)$. Aal spermatogonia are the source of primary spermatocytes that will enter meiosis and further develop into haploid spermatids and sperm (205). Nevertheless, further studies have revealed that morphology alone is not sufficient to characterize spermatogonial cells. Undifferentiated spermatogonia were firstly identified as being negative for the surface receptor Kit $(206,207)$. However, more recent studies have revealed a more heterogeneous characterization of undifferentiated spermatogonia and several markers can now be used to identify SSCs. Comparison of gene expression by whole-mount double-staining of seminiferous tubules revealed that the transcription factor Plzf (promyelocytic leukemia zincfinger) $(208,209)$ and the calcium dependent cell-cell adhesion glycoprotein E-Cadherin (210) have identical expression patterns and are present in all A spermatogonia (211). In contrast, the cell surface receptor Gfra 1 and the transcription factor Nng3 showed a more heterogeneous expression, where As, Apr and Aal can be stratified into Gfra 1 single-positive, Gfra1/Ngn3 double positive, and Ngn3 single-positive. The shorter chains of cells have a greater probability of being Gfral single-positive while longer chains tend to be Ngn3 single-positive (211-213). Moreover, the m-RNA binding protein Nanos C2hc-Type Zinc Finger 2 (Nanos2) promotes the male fate while suppressing meiosis in embryonic XY germ cells (214). Recently, pigs with heterozygous and homozygous mutations in Nanos2 were generated using the CRISPR/Cas9 system. Males pigs had an impaired development 


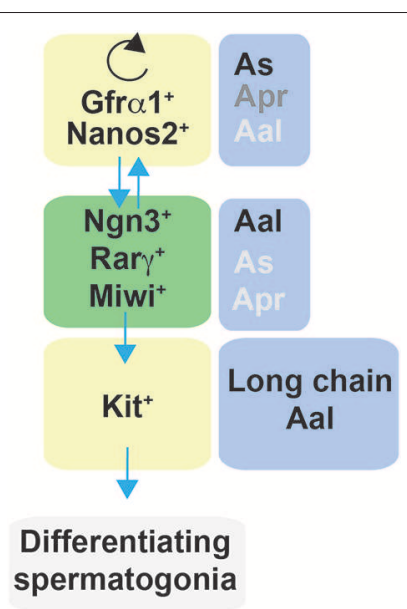

FIGURE 7 | Schematic representation of factors affecting self-renewal and differentiation of spermatogonia in mice. Spermatogonia are classified as Asingle (As), Apaired (Apr), and Aaligned (Aal) according to the number of cells contained in a syncytium. In steady-state, a subset of Gfra1/Nanos2 expressing cells function as stem cells with the ability to self-renew their population. Gfra $1^{+}$spermatogonia have the ability to generate cells that lose the expression of Gfra 1 and become $\mathrm{Ngn}^{+} / \mathrm{Rar}^{+} / \mathrm{Miwi}^{+}$, which can retain the stem cell potential but mostly become $\mathrm{Kit}^{+}$cells, and therefore are committed to terminal differentiation. In regenerative contexts,

$\mathrm{Ngn3}^{+} /$Rar $\gamma^{+} / \mathrm{Miwi}^{+}$can regain Gfra 1 expression contributing to the self-renewing pool.

of testis, specifically homozygous Nanos2 knockout had no germ cells in the presence of intact seminiferous tubules (215). Nanos2 was found to be almost exclusively expressed in As to Apr cells, whereas Nanos3 is detectable in most undifferentiated spermatogonia (As to Aal) (214). This heterogeneity of gene expression has suggested functional heterogeneity within the same cluster of cells (i.e., As, Apr, Aal) (Figure 7).

Lineage tracing, live imaging and pulse labeling studies have revealed that differentiation of spermatogonia is more complex that previously described and have led to a revision of the traditional "As model." In steady-state, a subset of $\mathrm{Gfr} \alpha 1^{+}$cells resides on the top of the hierarchy (211) and function as stem cells with the ability to self-renew their population while maintaining a constant number of $\mathrm{Gfr} \mathrm{1}^{+}$spermatogonia (216). Moreover, Gfr $\alpha 1^{+}$spermatogonia were shown to continually interchanged between As, Apr and Aal spermatogonia through a combination of incomplete division and syncytial fragmentation. At the same time, all categories of As, Apr, and Aal Gfr $\alpha 1^{+}$spermatogonia had the ability to generate cells that lose the expression of Gfr $\alpha 1$ and become positive for Ngn 3 . Ngn $3^{+}$cells, independently from the chain length (including As cells), are destined for differentiation and become $\mathrm{Kit}^{+}$which undergo several further rounds of cell division and are committed to terminal differentiation. Eventually all $\mathrm{Kit}^{+}$cells are derived from $\mathrm{Ngn}^{+}$ cells $(211,213)$. Interestingly, these studies also demonstrated that $\mathrm{Ngn}^{+}$cells retain the capability of regaining GFR $\alpha 1$ expression, fragmenting into single cells or shorter syncytia (through breaking of intercellular bridges), and contributing to the long-term stem cell pool. This reversion is rare in homeostasis but becomes more frequent during regeneration, for example after tissue insult by a cytotoxic reagent or transplantation (211, 217). Therefore, $\mathrm{Ngn}^{+}$spermatogonia have been referred to as "potential stem cells" $(211,217)$. In this context, further studies have identified other subpopulations of undifferentiated cells that contribute to the self-renewing pool. Carrieri et al. identified a novel population of $\mathrm{Ngn}^{+}$spermatogonia that express the Piwi protein Miwi2, which was shown by cell ablation to be crucial for efficient regenerative spermatogenesis after injury (218). More recent studies have further characterized germline stem cells; for example, Gfr $\alpha 1^{+}$cells comprise subpopulations that express the transcription factor Pancreatic and duodenal homeobox 1 (Pdx1) (219), the Erb-B2 Receptor Tyrosine Kinase 3 (Erbb3) (220), Inhibitor of differentiation 4 (Id4) (221) and Shisa family member 6 |(Shisa6) (222).

Spermatogonia reside within specialized microenvironments - referred as "niches" - in the basal compartment of seminiferous tubules. A undifferentiated spermatogonia, including Gfr $\alpha 1^{+}$ subpopulation, localize preferentially to the area adjacent to the vasculature network of arterioles and venules that accompanies interstitial cells $(216,223,224)$. On making the transition into differentiating spermatogonia, they migrate out of these areas and disperse over the entire basal compartment of the seminiferous epithelium (225). Interestingly, live-imaging revealed that $\mathrm{Gfr} 1^{+}$cells intersperse between $\mathrm{Ngn}^{+}$and $\mathrm{Kit}^{+}$ spermatogonia and are in constant movement in the basal compartment where they actively migrate between Sertoli cells (216). Such a microenvironment can be designated as an open stem cell niche.

Although the molecular mechanisms governing the maintenance and fate of $\mathrm{A}$ undifferentiated spermatogonia are yet not fully understood, Sertoli cells are widely regarded as key contributors to the maintenance and differentiation of SSCs, being the main source of the Glial -derived neurotrophic factor (Gdnf) (the ligand for GFR $\alpha 1$ receptor complex), and Fgf2 (226). For example, in vivo overexpression and lossof-function models show that the dosage of Gdnf regulates accumulation/depletion of undifferentiated spermatogonia (227), and in vitro stimulation with Ggnf leads to proliferation of GFR $\alpha 1^{+}$cells (212). Gdnf-mediated proliferation of SSCs involves regulation of Src family kinases, Yes, Lyn and Fyn. Gdnf activates Src family kinases, which further stimulate the phosphoinositide 3-kinase (PI3K)/Akt pathway (228) and upregulates N-Myc expression to promote SSCs proliferation (229). More recently, further studies revealed that Gdnf production is regulated by the canonical Notch pathway $(191,230)$ via the transcriptional repressors Hes1 and Hey (231). Fgf2 was shown to expand GFR $\alpha 1^{+}$cells, although these cells had a distinct phenotype from Ggnf. Fgf2 expanded a retinoic acid receptor $\gamma$ (Rar $\gamma$ ) expressing subset of cells showing Fgf2 function to be more appropriate for spermatogonial differentiation (226). It is known that retinoic acid (RA), which is synthesized from Vitamin A, is required for spermatogonial differentiation $(232,233)$. The generation of $\mathrm{Kit}^{+}$spermatogonia was blocked in the testes of Vitamin A deficient mice and reinitiated after administration of Vitamin A. Lineage-tracing analysis revealed that $\mathrm{Ngn}^{+}$cells (but not $\mathrm{Gfr}^{+} 1^{+}$), which 
specifically express Rar $\gamma$, transit to $\mathrm{Kit}^{+}$cells rapidly and efficiently in response to RA (234). Fgf2 signaling is dependent on Map2k1 pathway activation to drive SSC self-renewal via upregulation of the transcription factor Ets variant 5 (Etv5) and transcriptional repressor B-cell CLL/lymphoma 6, member B (Bcl6b) (235). Another study indicated that Fgf2 may regulate SSCs proliferation in vitro via phosphorylation on Akt and Erk1/2 pathway (236). Finally, it should be mentioned that the activation of the $\mathrm{Wnt} / \beta$-catenin pathway is thought to drive the transition from $\mathrm{Gfr} \alpha 1^{+}$to $\mathrm{Ngn}^{+}$spermatogonia, and signaling is likely initiated by Wnt6, which is uniquely expressed by Sertoli cells $(222,237,238)$. Evidence for the importance of Sertoli cells as supporting/regulatory cells also comes from in vivo knockout experiments, which identified Sertoli cell specific genes, for example Connexin 43 (cx43), Swi-independent 3a (Sin3a), cytochrome P450 enzymes (Cyp26b1), and Ets related molecule (Erm), some of which play a role in the above pathways, that are essential in supporting germ cell proliferation and/or survival (239-242) and normal spermatogenesis (243).

Another factor which is important for the maintenance of the SSCs pool is oxygen availability. The microenvironment where SSCs reside can be described as being low in oxygen (or hypoxic), a condition that induces the activation of transcription factor hypoxia inducible factor $1 \alpha(\mathrm{HIF} 1 \alpha)$ and can inhibit cell differentiation (244). Staining of adult testis revealed the expression of HIF1 $\alpha$ in the stem cell niche along the basement membrane of the seminiferous tubules, while the signal diminishes as cells differentiate, implying a possible role of Hif $1 \alpha$ in germ cell development (245).

Another important question is the extent to which the knowledge acquired using rodents can be applied to humans. Human spermatogonia are characterized by their nuclear morphology and staining with haematoxylin as Adark and Apale spermatogonia (246). Adark spermatogonia are thought to function as reserve stem cells, whilst Apale spermatogonia are progenitors of spermatocytes. Nevertheless, their identity, self-renewal and differentiation abilities are just beginning to emerge. Prepubertal human spermatogonia showed expression of genes important in mouse SSCs regulation (247). Immunohistochemistry on tubule sections revealed human spermatogonial cells share some (i.e., GFR $\alpha 1$ ) of the markers found in rodents (248). More recently, three independent groups revealed using single-cell RNA-sequencing in human testis clear evidence for heterogeneity and identified distinct cell clusters including SSCs (249-251). These findings provide a starting point for further studies, such as the evaluation of SSC frequency and assessment of SSC activity (252).

Leydig cells, the testosterone-producing cells of the adult testis, derive from stem Leydig cells, spindle-shaped cells that lack steroidogenic cell markers (253). Once formed, Leydig cells rarely die or divide. Nevertheless, their depletion in conditions such as ethane dimethanesulfonate is followed by the appearance of new, fully functional adult Leydig cells $(254,255)$, which are thought to arise from precursors stem cells (254). Very recently, it was shown in male rats that Fgf-homologous factor-1 (Fhf1 or Fgf12), an intracellular protein, is abundant in Leydig cells and that injection of Fhf1 resulted in Leydig cells regeneration from precursor stem cells in rats where Leydig cells were pharmacologically ablated (256).

In contrast, one study reported that complete ablation of Sertoli cells in vivo, either in fetal life (e16.5) or post-natal life, did not lead to repopulation of the testis with new Sertoli cells, indicating Sertoli cells do not possess regenerative capacity and no stem Sertoli cells are present in adult testis (257).

\section{Stem Cells and Regenerative Medicine in the Testis}

In recent years, the pluripotency characteristics of SSCs has emerged. For example, the generation of pluripotent embryonic stem like cells was established from neonatal mice testis (258). Similarly, in humans SSCs yielded human testis-derived embryonic stem-like cells (htESLCs) (259, 260); htESLCs were shown to differentiate in vitro into derivatives of all three germ layers including neural, epithelial, osteogenic, myogenic, adipocyte, and pancreatic lineages (261). Therefore, SSCs are considered a feasible source for applications in regenerative medicine.

Adverse effect of cancer treatments in men include long-term infertility. If cancer occurs after puberty sperm cryopreservation is the simplest and the most effective method to preserve fertility, nevertheless in prepubertal patients this is not an option. The self-renewal and differentiation abilities of SSCs make these cells a promising tool in the treatment of infertility. To this end, cryopreservation of testicular tissue before chemo-therapy and later autotransplantation of SSCs could theoretically be used to restore fertility. In this context promising results have been obtained in animals. Already in 1994, Brinster and Zimmermann showed that male mice stem cells injected into seminiferoustubules repopulated sterile testes and donor recipients produced mature spermatozoa (262). Human germ cells xenotransplanted to testes of busulfantreated mouse (with suppressed spermatogenesis) testes survived for at least 6 months and proliferated during the first month after transplantation, however no human-differentiating spermatogonia were identified (263). Similarly, spermatogonia in the testis of a prepubertal boy were shown to migrate to the basement membrane of the mouse recipient seminiferous tubule and were maintained as germ cells (247). Human testicular cells from adult men were isolated, maintained and proliferated in vitro for longer than 20 weeks. In 4 out of 6 men, even after prolonged in vitro culture, xenotransplantation to mice demonstrated the presence of functional SCCs (264). Importantly, testicular cells from a 6.5- and 8-year-old boys were cultured in vitro for at least 15.5 weeks (265). Elhija et al. established a 3D agar culture system which was able to induce germ testicular cells from mice to generate morphologically normal spermatozoa (266). Sato et al. reported the use of an in vitro organ culture method that supported complete mouse spermatogenesis (267, 268); subsequently this methodology was used to generate viable sperm, which through micro-insemination resulted in healthy offspring (269). Although it might take a while before the first clinical trial 
of SSCs autotransplantation is granted, these pre-clinical data are promising.

\section{OVARY}

\section{Key Pathways Guiding Ovary Development}

In females, PGCs divide by mitosis with incomplete cytokinesis until around e13.5 in mice and 11-12 weeks in humans producing germ cell cysts (also called germ cell nests) (Figure 8) (270). Mitotic division ends and germ cells enter meiosisI and arrest in the diplotene stage of prophase-I eventually becoming oocytes (271). Germ cell cysts start undergoing breakdown (starting at around e18 until post-natal day 5) to produce primordial follicles (primordial follicle pool) consisting of a single oocyte surrounded by pre-granulosa cells (272274). At this time, the ovary is reorganized into morphological compartments, the cortex (containing primordial follicles) and the medulla. During a process called folliculogenesis primordial follicles further develop to become potential fertilizable eggs at sexual maturity. During a first phase (the preantral phase), primordial follicles mature into primary and secondary follicles. In a second phase (the antral or gonadotropin-dependent phase) granulosa cells secrete follicular fluid generating fluidfilled antral follicles. After the onset of puberty, activation and further maturation of follicles lead to oocytes ovulation. Just before ovulation, oocytes complete the first meiotic division and begin the second meiotic division which is completed only after fertilization.

Factors that determine ovarian specification include members of the Wnt/ $\beta$-catenin pathway. Expression of Wnt 4 is firstly detected from e10 onwards. When sex specific differentiation begins, Wnt4 is downregulated in males and continues to be expressed in females. Ovaries of $\mathrm{Wnt}^{-/-}$appeared masculinized (absence of Müllerian duct and development of Wolffian duct) indicating that Wnt4 is a determinant of the female gonad (275). A mutation in the human R-spondin1 (RSPO1) gene, was shown to be responsible for female-to-male sex reversal. Moreover, the same study reported that Rspol is expressed specifically in XX gonads of mice during the critical stage (e13-15) of gonad differentiation (276). Female Rspo1-1mice showed male phenotypic features similar to what observed in $\mathrm{Wnt}^{-/-}$mice (277). Another factor involved in ovarian determination is the transcription factor Foxl2, which is detected in female mice as early as e12.5. Foxl $2^{-/-}$female mice revealed Foxl2 is required for ovarian follicle formation $(278,279)$. Moreover, Wnt4 $4^{-/-}$Foxl2 ${ }^{-/-}$double knockout ovaries resulted in the formation of testis tubules and harbored well-differentiated spermatogonia (280).

\section{Stem Cells and Self-Renewal in Ovary}

For many years, the mammalian ovary was thought to contain at birth a fixed non-renewing pool of oocyte-containing follicles, that are depleted to exhaustion with aging (281). However, in 2004, Johnson et al. (282) challenged this notion. The group counted the number of atretic (degenerating follicles) and nonatretic (healthy) follicles in ovaries of mice. Based on the number of degenerating follicles at any given time under normal conditions they predicted complete exhaustion of the follicle reserve by young adulthood. Nevertheless, the number of nonatretic follicles declined less than expected. Thus, they speculated that germ line stem cells are present in the post-natal ovary of mice. Not surprisingly, this study ignited a debate on the possibility of post-natal neo-oogenesis in mammals $(283,284)$, and prompted follow-up investigations. Convincing evidence of the presence of female germline stem cells (FGSCs) [also known as oogonial stem cells (OSCs) (285)] in the mammalian ovary was provided for the first time in 2009 by Zou et al. Firstly, putative FGSCs were identified in neonatal and adult mice ovaries by dual immunofluorescence analysis of BrdU incorporation and mouse vasa homolog (Mvh, a germ-cell marker). Subsequently, FGSCs were isolated from neonatal (nFGSCs) and adult (aFGSCs) mice ovaries by two-step enzymatic digestion and immunomagnetic isolation of Mvh-positive cells. These cells were maintained in culture for months and expressed markers of germline cells and proliferation. Furthermore, when GFP labeled aFGSCs were transplanted into ovaries of infertile mice (sterilized by pretreatment with cyclophosphamide and busulfan), histological evaluation after 2 months showed that ovaries had many oocytes at all stages of development, including GFP-positive oocytes, suggesting that oocytes can be regenerated in sterile recipient females by transplantation of FGSCs. Ultimately, the transplanted mice produced offsprings that had the GFP transgene (286). Following this study, within a short period of time, similar data were generated. A wealth of literature reported the isolation of mitotically active germ cells from adult animals mainly using magnetic-assisted cell sorting or FACS and subsequent culture of the isolated cells (287-295) [also reviewed by (285)]. Importantly, by the use of FGSCs intragonadal transplantation-base approaches, these studies also confirmed the functional capacity of mouse FGSCs to restore ovarian function and produce offsprings $(287,294,296)$.

For a few years, possibly partly due to the lack of appropriate methodology (297), the question of whether FGSCs actually contribute to oocytes during de novo folliculogenesis in female adult mice under physiological conditions remained unresolved (298-300). Finally, compelling evidence was provided by the use of a tamoxifen-inducible system that traced Oct4- expressing cells permanently marked with enhanced yellow fluorescent protein (EYFP) in post-natal mouse ovaries. This line of evidence proved the existence of active ovarian germ stem cells in vivo and their function in replenishing the primordial follicle pool under physiological conditions (301). Soon after, this result was confirmed by inducible ablation of premeiotic germ cells undergoing differentiation into oocytes driven by the promoter of Stimulated by Retinoic Acid gene 8 (Stra8). With this approach, the study demonstarted that new oocytes are formed in ovaries during adult life and that some of these oocytes contribute directly to the pool of oocytes used for natural reproduction (302).

Aside from the numerous animal studies that have populated the literature since the traditional view of a finite pool of oocytes was challenged (282), human investigations have also emerged. A significant progress in the field was made when viable $\mathrm{Mvh}^{+}$cells were isolated from human ovarian cortical tissue and maintained 


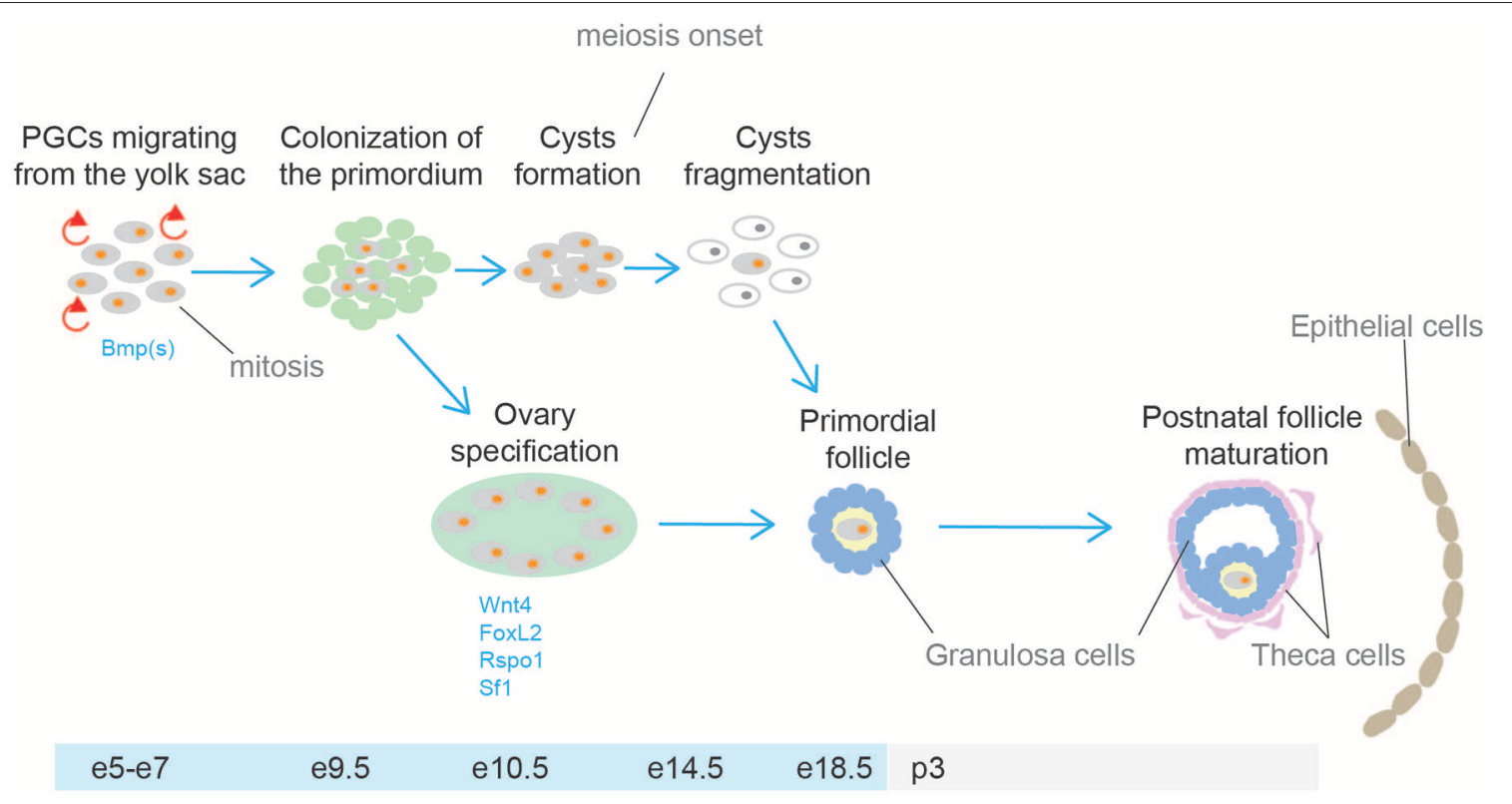

FIGURE 8 | Schematic representation of ovary development. Primordial germ cells (PGCs) colonize the gonadal primordium and undergo mitotic division with incomplete cytokinesis producing cysts. Subsequently, germ cell cysts undergo breakdown to produce primordial follicles, consisting of a single oocyte surrounded by pre-granulosa cells. During sexual maturation, primordial follicles develop further eventually becoming potential fertilizable eggs at sexual maturity.

in vitro where they spontaneously generated oocytes as confirmed via morphological and gene expression analyses and attainment of haploid status. $\mathrm{Mvh}^{+}$cells isolated from adult human ovaries were stably transduced with a GFP expression vector, injected in adult human ovarian cortical tissue biopsies and then xenografted into female mice where formation of follicles containing GFP-positive oocytes was observed (303). Similar results were independently obtained by other groups (304-307).

With multiple laboratories now confirming the existence and functional characteristics of FGSCs, new studies have recently emerged in the attempt to investigate their biological activities and regulatory mechanisms (i.e., self-renewal, differentiation, apoptosis). Zhang et al. reported that Cadherin 22 (Cdh22), a member of cadherin family, is required for FGSCs self-renewal via different mechanisms, including interacting with the JakStat and $\beta$-catenin signaling pathways (308). In a follow-up study, the same group showed that Cdh22 interacts with Pik3 to phosphorylate Akt3, which enhanced the expression levels of N-Myc and members of the cyclin family to promote selfrenewal. Moreover, Gdnf was also shown to be essential for FGSC self-renewal via a more complicated mechanism: Gdnf-Gfr $\alpha 1$ activates Akt3 via PI3K or Src family kinase (Sfk), and Sfk upregulates its target genes, Bcl6b, Etv5, and Lhx1. Nevertheless, Src, the key intermediate factor for SSCs, was not the functional molecule of Sfk family in the Gdnf signal network of FGSCs (309).

The origin of FGSCs has been debated for years. Soon after their first pubblication, Johnson et al. suggested bone marrow as a potential source of female germ cells (310). However, a later study showed, by the use of transplantation and parabiotic mouse models, no evidence that bone marrow cells, or any other normally circulating cells, contribute to the formation of mature ovulated oocytes both in the steady state and after induced ovarian damage (311). A follow-up investigation by Lee at al. reported conflicting conclusions. Transgenic mice with germline-specific expression of GFP underwent bone marrow transplantation (BMT) after injection with busulfan and cyclophosphamide. BMT rescued fertility, but all offspring derived from the recipient germline (312). More recently, positive results came from injection of human bone marrow-derived stem cells (BMDSC) into mice with chemotherapy-induced ovarian damage. BMDSC treatment resulted in production of higher numbers of preovuolatory follicles, metaphase II oocytes, 2-cell embryos, and healthy pups (313).

While much research of stem cells in ovary has focused on FGSCs, indication of normal somatic stem cells has also been provided. The work by Honda et al. showed evidence in newborn mice ovaries of putative thecal stem cells with the ability to self-renew and differentiate in vivo and in vitro. These putative thecal stem cells formed characteristic anchor-independent round colonies, and, after stimulation, started to differentiate and show characteristic signs of steroidogenesis. Moreover, after transplantation into ovaries these putative thecal stem cells showed aggregation immediately adjacent to developing follicles and in both theca interna and externa during folliculogenesis (314). Using BrdU incorporation and doxycycline inducible histone2B-green fluorescent protein pulse-chase techniques, Szotek et al. identified a putative somatic stem/progenitor cell in the ovarian surface epithelium (OSE) in the adult mouse ovary. Interestingly, Virant-Klun et al. isolated and characterized putative ovarian stem cells obtained from the OSE of the adult 
human ovary in women with no naturally present oocytes and follicles. Small round cells $(2-4 \mu \mathrm{m})$ with a bubble-like structure that expressed early embryonic developmental markers were separated and cultured in vitro where they proliferated, with some cells reaching a diameter of $\sim 20 \mu \mathrm{m}$ after 5-7 days (315, 316). Since their discovery, somatic stem cells in the ovary have been of particular interest as these cells may be responsible for ovarian cancer during adult life as well as neo-oogenesis [reviewed by (317)].

\section{Stem Cells and Regenerative Medicine in the Ovary}

The finding of FGSCs in adult human ovaries promts the question whether these cells can be utilized somehow to enhance, prolong or restore fertility in women. Although this might seems a far-fetched scenario, reproductive biologists are already working toward this goal. One possiblity is a procedure known as "Autologous germile mitochondrial energy transfer (AUGMENT)," which involves the use of patient matched FGSCs mitochondria to invigorate oocytes of women with a history of poor egg and embryo quality (318). Another option is based on autologous oocytes transplantation approaches to prolong or restore ovarian function. This would include the development of techniques designed to reconstitute human ovarian tissue which would allow the production of functional eggs from FGSCs entirely ex vivo (285). While there is a long way ahead, these techniques would offer women faced with fertility challenges a unique opportunity for bearing a genetically-matched child.

\section{ENDOCRINE PANCREAS}

\section{Endocrine Function in the Pancreas}

The pancreas contains both an exocrine and endocrine component, with the endocrine system accounting for $\sim 5-15 \%$ of the total pancreas. The exocrine pancreas is composed of acinar cells that secrete digestive enzymes into the pancreatic duct and assist with digestion. The five main cell types of the endocrine pancreas are located within clusters of cells known as the islet of Langerhans, which include: glucagon-producing $\alpha$ cells, insulin-producing $\beta$ cells, somatostatin-producing $\delta$ cells, ghrelin-producing $\varepsilon$ cells and polypeptide-producing PP cells. The $\alpha, \beta, \delta$, and PP cells play critical roles in maintaining physiologic blood glucose levels, while $\varepsilon$ cells play a role during fetal development, but they are virtually absent in the adult pancreas. During periods of elevated blood glucose, which occurs after food ingestion, $\beta$ cells release insulin which signals to the liver, adipose tissue and skeletal muscle to increase glucose uptake. Conversely, during periods of low blood glucose, $\alpha$ cells secrete glucagon, triggering hepatic glycogen breakdown and glucose secretion into circulation. Somatostatin is known to inhibit both insulin and glucagon secretion, and PP inhibits glucagon release in low-glucose conditions. Together, through the concerted release of these hormones, blood glucose levels are able to remain within a physiologic range (319).

\section{Key Pathways Guiding Pancreas Development}

During embryonic development, the pancreas emerges from the endoderm, a primordial germ cell layer that gives rise to the digestive and respiratory tracts and their derivative organs. Pancreas development begins around e9.5 in the mouse, at which time the dorsal bud emerges from the Pdx1-expressing region of the posterior foregut, followed by the ventral bud at e10.0 (320-322). Following a 180-degree rotation around the duodenum, the dorsal and ventral buds fuse to form a single pancreatic anlage. The pancreatic epithelium begins to protrude and undergoes extensive remodeling and formation of a web-like structure, or plexus (320). During this time, the surrounding mesenchyme secretes factors such as Fgf10 and Egf, which are critical for pancreas differentiation and proliferation $(320,323,324)$. During plexus remodeling, signaling from the surrounding mesenchyme and polarization of epithelial cells lead to the formation of regions with distinct developmental potential: the tip contains the multipotential pancreatic cells (MPCs) and the trunk contains bi-potent endocrine/ductal progenitors (Figure 9). The multipotent progenitors express Pdx1, Pancreas Associated Transcription Factor 1a (Ptf1a), NK6 Homeobox 1(Nkx6-1), Carboxypeptidase A1 (Cpa), Myc, and Sox9 and provide a source of cells that can become endocrine, ductal and acinar cells (325-332). Cells of the trunk that undergo endocrine and ductal commitment continue to express $N k x 6$ 1 , a transcription factor required for $\beta$ cell development, but lose expression of Ptfla, a transcription factor that becomes restricted to acinar cells $(333,334)$. As cells commit to the endocrine lineage, the pancreatic epithelium and mesenchyme get connected to the vasculature and become less hypoxic, HIFla (a marker of hypoxia) expression decreases and cells of the epithelium upregulate $N g n 3$, a basic loop helix transcription factor marking all endocrine progenitors (335-337). In order for cells to undergo endocrine differentiation and upregulate Ngn3 expression, Notch signaling must be downregulated $(338,339)$. In addition to Notch inhibition, recent work by a number of groups have demonstrated that inhibition of Wnt, Tgf $\beta$ and Hippo (through the downregulation of its effector Yes Associated Protein, Yap) signaling further enhances human endocrine differentiation (Figure 9) (340-342). The mechanism by which endocrine cells form the islet of Langerhans had been thought to occur as a result of delamination of individual endocrine cells, followed by their subsequent coalescence. This paradigm has recently been challenged by Sharon et al., who proposed that islets form from peninsula-like structures (340, 343-345). In this model, Sharon et al. demonstrated that endocrine cells maintain cellular contact during islet formation: $\alpha$ cells are believed to initially emerge from the trunk region to form the peripheral cells of the islet, followed by the emergence of $\beta$ cells, which maintain contact with the $\alpha$ cells, in order to form the islet core. At least in the mouse, the final size of the organ is dictated by the number of progenitors that arise during embryonic development and contrary to other organs, such as the liver, the pancreas has very limited proliferative potential in adults (346). 


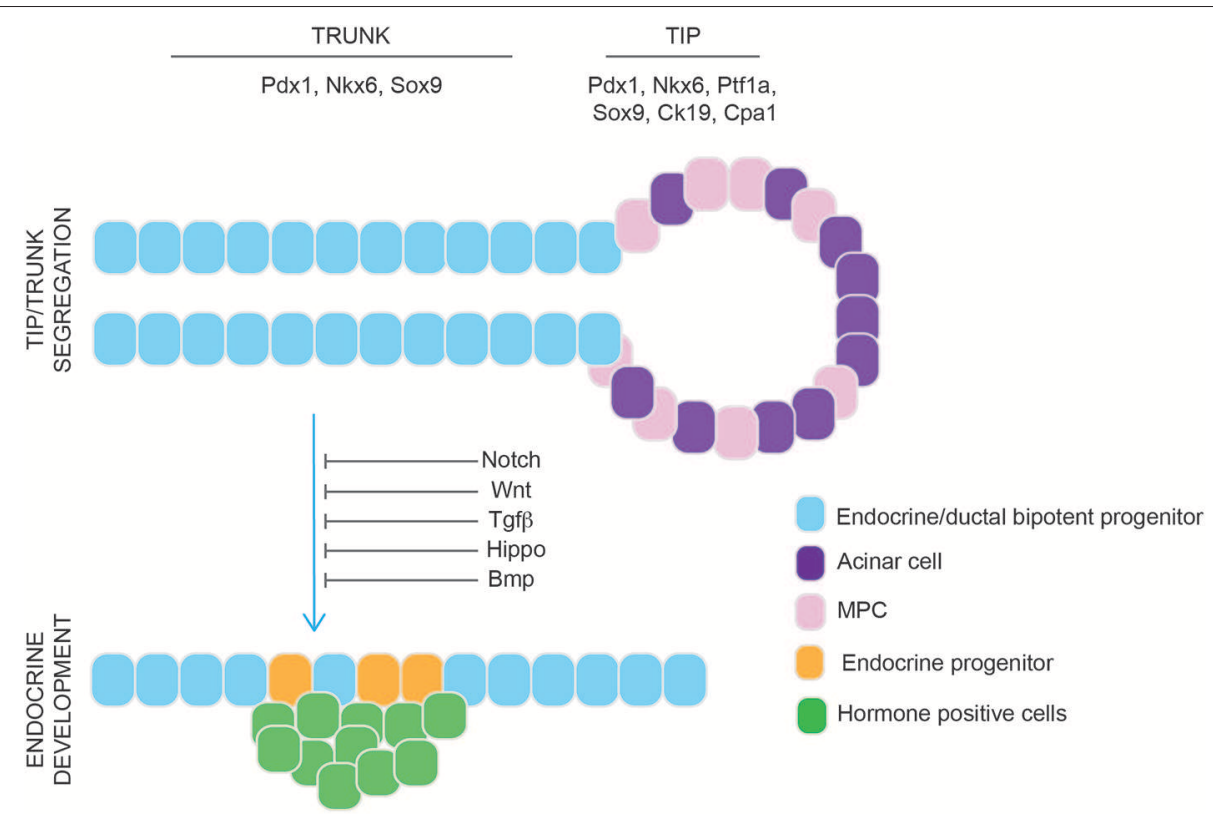

FIGURE 9 | Schematic representation of murine pancreatic development. Multipotential Pancreatic Cells (MPC) (pink) and acinar cells (purple) are located at the tip of the pancreatic epithelium. The trunk contains endocrine/ductal bipotent progenitors (light blue) that migrate out of the epithelium and differentiate to endocrine progenitor cells (orange) which give rise to hormone positive cells (green cells). Endocrine commitment is driven by inhibition of Notch, Wnt, Tgf- $\beta$, Hippo, and Bmp signaling pathways.

\section{$\beta$ Cell Regeneration in the Pancreas}

The proliferative capacity of the endocrine pancreas gradually decreases after birth, with $\beta$ cells showing minimal evidence of proliferation and turnover (347). However, $\beta$ cell mass increases during pregnancy, suggesting that an increase in $\beta$ cell mass can occur under physiological conditions (348). Therefore, understanding the mechanisms guiding $\beta$ cell regeneration has been of particular interest as this knowledge could potentially be leveraged to intentionally increase $\beta$ cell mass as a treatment for diabetes.

The main mouse models used to study pancreatic regeneration, which have been eloquently reviewed (349), include: pancreatic duct ligation, partial pancreatectomy (removal of $50-75 \%$ of the pancreas), chemical induced pancreatitis, and $\beta$ cell ablation models caused by drug administration, such as alloxan or streptozotocin (349). Partial pancreatectomy (Ppx) has historically been the most common model to study regeneration as it leads to both acinar and islet cell regrowth, making it an interesting model for $\beta$ cell regeneration $(350,351)$. Although ductal cells have been identified in some Ppx models to be the source of acinar and $\beta$ cell regeneration, lineage tracing studies suggest that pancreatic regeneration occurs through selfrenewal, where acinar cells generate new acinar cells and $\beta$ cells generate new $\beta$ cells (352-355). Using an insulin lineage tracing mouse model to label terminally differentiated $\beta$ cells, in combination with a Ppx mouse model, Dor et al. identified that the main source of $\beta$ cell generation is through self-renewal (352). Supporting this idea, using a DNA analog-based lineage tracing method in order to detect each round of cell division, Teta et al. demonstrated that $\beta$ cells come from pre-existing $\beta$ cells and not a source of stem/progenitor cells in the adult pancreas (356). Recent publications have shown that $\beta$ cell heterogeneity exist within the islet, with some $\beta$ cells having been identified as being more proliferative and immature than other $\beta$ cells. The heterogeneity that exists could explain the ability of some $\beta$ cells to be capable of self-renewal, while the less proliferative $\beta$ cells cannot (357-359).

If, however, $\beta$ cell regeneration occurs through the proliferation of existing $\beta$ cells, self-renewal would not explain $\beta$ cell regeneration in mouse models of type 1 diabetes where nearcomplete $\beta$ cell ablation occurs. Interestingly, in a mouse model containing a transgene for an insulin promoter and diphtheria toxin (DT) receptor sequence that can result in up to $>99 \%$ ablation of $\beta$ cells following DT treatment, $\beta$ cell regeneration was shown to occur as early as 15 days post-DT treatment. In this model, using lineage tracing to label glucagon-producing $\alpha$ cells prior to DT-treatment (360), $\beta$ cell regeneration from $\alpha$ cells was demonstrated. The ability of $\alpha$ cells to transdifferentiate to $\beta$ cells introduces the idea that endocrine cells retain plasticity, which has been the basis for efforts to identify compounds that could modulate $\alpha$ to $\beta$ transdifferentiation, but so far with no success (361-363).

Additionally, other studies suggest that insulin expressing cells are in fact the stem cells of the pancreas, being able to generate other exocrine and endocrine tissues (364). More recent work identified pancreatic cells within an islet-depleted cell population, such as ductal tissue, that can generate insulin-expressing cells following transplantation in mice, suggesting a non-endocrine 
progenitor-like population exists that can also generate insulin producing cells (365).

Overall these studies indicate that the type of stress caused by pancreatic injury and/or the resulting environment may dictate the source of $\beta$ cell regeneration, thereby adding to the difficulty in deciphering the mechanisms of $\beta$ cell regeneration in a natural and physiological manner in humans.

\section{Stem Cells and Regenerative Medicine in Pancreas}

In addition to generating $\beta$ cells through regeneration, using cadaveric donors or human pluripotent-stem cells (hPSCs) offers another source of $\beta$ cells for therapy. Human cadaveric islets and whole pancreas transplantation have been performed for patients with type 1 diabetes and have demonstrated the ability to normalize glycemia. However, the requirement for numerous donors for each patient, potential requirement for a subsequent transplant, and lack of donors have made hPSC-derived $\beta$ cells a more compelling source of cells for the treatment of diabetes. The most efficient differentiation protocols to date attempt to recapitulate key stages of pancreas development in vitro, including: (1) definitive endoderm formation, (2) posterior foregut patterning, (3) Pdx1 induction, (4) pancreatic progenitor generation $\left(\mathrm{Pdx}^{+} / \mathrm{Nkx}^{-}-^{+}\right.$cells), (5-6) endocrine commitment ( $\mathrm{Ngn}^{+}$cells), and (7) $\beta$-like cells differentiation $\left(\mathrm{Nkx6-1^{+ }} \mathrm{Cpep}^{+}\right.$cells) $(340,341,366-370)$. Pancreatic progenitors offer an appealing source of cells for transplantation as they give rise to all cells of the pancreas following transplantation in mice and can normalize glycemia in an streptozotocin-induced diabetic mouse model of diabetes $(367,368,371)$. Supporting the use of hESC for the treatment of diabetes, ViaCyte ${ }^{\mathrm{TM}}$ has launched several clinical trials to test the safety of pancreatic progenitor transplantation in humans (NCT02239354, NCT02939118, NCT03162926, NCT03163511). Outcomes of these initial clinical trials will provide knowledge that will be the basis of future hPSC-derived pancreatic transplantations. Although PPs have demonstrated the ability to normalize glycemia in mice, generating $\beta$ cells in vitro from hPSC may allow for a more efficient means to normalize glycemia and contain a more committed endocrine population

\section{REFERENCES}

1. Perez-Castro C, Renner U, Haedo MR, Stalla GK, Arzt E. Cellular and molecular specificity of pituitary gland physiology. Physiol Rev. (2012) 92:1-38. doi: 10.1152/physrev.000 03.2011

2. Kusakabe M, Sakakura T, Sano M, Nishizuka Y. Early development of mouse anterior pituitary: role of mesenchyme. Dev Growth Differ. (1984) 6:263-71. doi: 10.1111/j.1440-169X.1984.00263.x

3. Pearson CA, Placzek M. Development of the medial hypothalamus: forming a functional hypothalamic-neurohypophyseal interface. Curr Top Dev Biol. 106:49-88. doi: 10.1016/B978-0-12-416021-7.0 0002-X

4. Charles MA, Suh H, Hjalt TA, Drouin J, Camper SA, Gage PJ. PITX genes are required for cell survival and Lhx3 activation. Mol Endocrinol. (2005) 19:1893-903. doi: 10.1210/me.2005-0052 that would not give rise to other cells of the pancreas, such as acinar cells. Therefore, generating hPSC-derived $\beta$ cells in vitro could provide a cell product that would be more efficient for diabetes therapy. In 2014, two groups identified protocols to generate Nkx6-1 $1^{+} /$serum-C-peptide (Cpep) ${ }^{+}$cells from hPSC in vitro, and although the hPSC-derived $\beta$-like cells could release insulin in response to a glucose challenge, further maturation only occurred following transplantation in mice $(372,373)$. More recent publications have claimed the generation of more functional $\beta$ cells from hPSC in vitro. However, efficiencies of these published protocols remain poor, with some protocols requiring fluorescence-activated cell sorting using a transgenic INS:GFP reporter cell line, and protocol reproducibility has yet to be confirmed $(341,342,370)$. Although signaling pathways guiding human $\beta$ cell differentiation have been identified in these reports and have helped push the field forward, generating a population of cells that is therapeutically relevant will require extensive improvements in the efficiency, purity, reproducibility, and functionality of hPSC-derived $\beta$-like cell directed differentiation protocols.

\section{AUTHOR CONTRIBUTIONS}

LG and KM contributed to sections on adrenal cortex, adrenal medulla, and gonads. GR-B contributed to sections on thyroid and parathyroids. CG-M, JN, and AG contributed to the section on pituitary. $\mathrm{MN}$ and EM contributed to the section on pancreas.

\section{FUNDING}

The authors' research was funded by Barts Charity (MGU0436 to LG and KM), Biotechnology and Biological Sciences Research Council (BB/L002671/1 to LG), Rosetrees Trust (M335-F1 to LG), Canadian Institute of Health Research (CIHR to MN), Toronto General and Western Hospital Foundation, Ontario Institute for Regenerative Medicine (OIRM to MN), Medicine by Design (to MN), Banting and Best Diabetes Centre (BBDC to $\mathrm{MN}$ ), Medical research Council MRC-CRTF (to JN), Action Medical Research (to CG-M), AFM-Telethon (to LG and GR-B), and H2020-MSCA-IF-2018 (to GR-B).

5. Raetzman LT, Ward R, Camper SA. Lhx4 and Prop1 are required for cell survival and expansion of the pituitary primordia. Development. (2002) 129:4229-39.

6. Davis SW, Mortensen AH, Camper SA. Birthdating studies reshape models for pituitary gland cell specification. Dev Biol. (2011) 352:215-27. doi: 10.1016/j.ydbio.2011.01.010

7. Bilodeau S, Roussel-Gervais A, Drouin J. Distinct developmental roles of cell cycle inhibitors p57Kip2 and p27Kip1 distinguish pituitary progenitor cell cycle exit from cell cycle reentry of differentiated cells. Mol Cell Biol. (2009) 29:1895-908. doi: 10.1128/MCB.01885-08

8. Lamolet B, Pulichino A-M, Lamonerie T, Gauthier Y, Brue T, Enjalbert $\mathrm{A}$, et al. A pituitary cell-restricted $\mathrm{T}$ box factor, tpit, activates POMC transcription in cooperation with pitx homeoproteins. Cell. (2001) 104:84959. doi: 10.1016/S0092-8674(01)00282-3

9. Ingraham HA, Chen $\mathrm{R}$, Mangalam HJ, Elsholtz HP, Flynn SE, Lin CR, et al. A tissue-specific transcription factor containing a 
homeodomain specifies a pituitary phenotype. Cell. (1988) 55:519-29. doi: 10.1016/0092-8674(88)90038-4

10. Ingraham HA, Lala DS, Ikeda Y, Luo X, Shen WH, Nachtigal MW, et al. The nuclear receptor steroidogenic factor 1 acts at multiple levels of the reproductive axis. Genes Dev. (1994) 8:2302-12. doi: 10.1101/gad.8.19.2302

11. Chen J, Gremeaux L, Fu Q, Liekens D, Van Laere S, Vankelecom H. Pituitary progenitor cells tracked down by side population dissection. Stem Cells. (2009) 27:1182-95. doi: 10.1002/stem.51

12. Fauquier T, Rizzoti K, Dattani M, Lovell-Badge R, Robinson ICAF. SOX2expressing progenitor cells generate all of the major cell types in the adult mouse pituitary gland. Proc Natl Acad Sci USA. (2008) 105:2907-12. doi: $10.1073 /$ pnas. 0707886105

13. Garcia-Lavandeira M, Saez C, Diaz-Rodriguez E, Perez-Romero S, Senra A, Dieguez C, et al. Craniopharyngiomas express embryonic stem cell markers (SOX2, OCT4, KLF4, and SOX9) as pituitary stem cells but do not coexpress RET/GFRA3 receptors. J Clin Endocrinol Metab. (2012) 97:E80-7. doi: 10.1210/jc.2011-2187

14. Gremeaux L, Fu Q, Chen J, Vankelecom H. Activated phenotype of the pituitary stem/progenitor cell compartment during the early-postnatal maturation phase of the gland. Stem Cells Dev. (2012) 21:801-13. doi: $10.1089 / \mathrm{scd} .2011 .0496$

15. Saint-Jeannet J-P, Moody SA. Establishing the pre-placodal region and breaking it into placodes with distinct identities. Dev Biol. (2014) 389:13-27. doi: 10.1016/j.ydbio.2014.02.011

16. Davis SW, Camper SA. Noggin regulates Bmp4 activity during pituitary induction. Dev Biol. (2007) 305:145-60. doi: 10.1016/j.ydbio.2007.02.001

17. Ericson J, Norlin S, Edlund T, Jessell TM. Integrated FGF and BMP signaling controls the progression of progenitor cell differentiation and the emergence of pattern in the embryonic anterior pituitary. Development. (1998) 125:1005-15.

18. Takuma N, Sheng HZ, Furuta Y, Ward JM, Sharma K, Hogan BL, et al. Formation of Rathke's pouch requires dual induction from the diencephalon. Development. (1998) 4840:4835-40.

19. Treier M, Gleiberman AS, O'Connell SM, Szeto DP, McMahon JA, McMahon AP, Rosenfeld MG. Multistep signaling requirements for pituitary organogenesis in vivo. Genes Dev. (1998) 12:1691-704. doi: 10.1101/gad.12.11.1691

20. Manning L, Ohyama K, Saeger B, Hatano O, Wilson SA, Logan M, et al. Regional Morphogenesis in the hypothalamus: a BMP-Tbx2 pathway coordinates fate and proliferation through shh downregulation. Dev Cell. (2006) 11:873-85. doi: 10.1016/j.devcel.2006.09.021

21. Treier M, O'Connell S, Gleiberman A, Price J, Szeto DP, Burgess R, et al. Hedgehog signaling is required for pituitary gland development. Development. (2001) 386:377-386.

22. Zhao L, Zevallos SE, Rizzoti K, Jeong Y, Lovell-Badge R, Epstein DJ. Disruption of SoxB1-dependent sonic hedgehog expression in the hypothalamus causes septo-optic dysplasia. Dev Cell. (2012) 22:585-96. doi: 10.1016/j.devcel.2011.12.023

23. Carreno G, Apps JR, Lodge EJ, Panousopoulos L, Haston S, GonzalezMeljem JM, et al. Hypothalamic sonic hedgehog is required for cell specification and proliferation of LHX3/LHX4 pituitary embryonic precursors. Development. (2017) 144:3289-302. doi: 10.1242/dev.153387

24. Trowe M-O, Zhao L, Weiss A-C, Christoffels V, Epstein DJ, Kispert A. Inhibition of Sox2-dependent activation of Shh in the ventral diencephalon by Tbx3 is required for formation of the neurohypophysis. Development. (2013) 140:2299-309. doi: 10.1242/dev.094524

25. Wang D, DuBois RN. Eicosanoids and cancer. Nat Rev Cancer. (2010) 10:181-93. doi: 10.1038/nrc2809

26. Aujla PK, Bora A, Monahan P, Sweedler J V., Raetzman LT. The Notch effector gene Hes1 regulates migration of hypothalamic neurons, neuropeptide content and axon targeting to the pituitary. Dev Biol. (2011) 353:61-71. doi: 10.1016/j.ydbio.2011.02.018

27. Kita A, Imayoshi I, Hojo M, Kitagawa M, Kokubu H, Ohsawa R, et al. Hes1 and Hes 5 control the progenitor pool, intermediate lobe specification, and posterior lobe formation in the pituitary development. Mol Endocrinol. (2007) 21:1458-66. doi: 10.1210/me.2007-0039
28. Raetzman LT, Cai JX, Camper SA. Hes1 is required for pituitary growth and melanotrope specification. Dev Biol. (2007) 304:455-66. doi: 10.1016/j.ydbio.2006.11.010

29. Zhu X, Gleiberman AS, Rosenfeld MG. Molecular physiology of pituitary development: signaling and transcriptional networks. Physiol Rev. (2007) 87:933-63. doi: 10.1152/physrev.00006.2006

30. Raetzman L, Ross S, Cook S, Dunwoodie S, Camper S, Thomas P. Developmental regulation of Notch signaling genes in the embryonic pituitary: Prop1 deficiency affects Notch2 expression. Dev Biol. (2004) 265:329-40. doi: 10.1016/j.ydbio.2003.09.033

31. Zhu X, Tollkuhn J, Taylor H, Rosenfeld MG. Notch-dependent pituitary SOX2 + stem cells exhibit a timed functional extinction in regulation of the postnatal gland. Stem Cell Rep. (2015) 5:1196-209. doi: 10.1016/j.stemcr.2015.11.001

32. Cheung L, Le Tissier P, Goldsmith SGJ, Treier M, Lovell-Badge R, Rizzoti K. NOTCH activity differentially affects alternative cell fate acquisition and maintenance. Elife. (2018) 7:e33318. doi: 10.7554/eLife.33318

33. Himes AD, Raetzman LT. Premature differentiation and aberrant movement of pituitary cells lacking both Hes1 and Prop1. Dev Biol. (2009) 325:151-61. doi: 10.1016/j.ydbio.2008.10.010

34. Potok MA, Cha KB, Hunt A, Brinkmeier ML, Leitges M, Kispert $A$, et al. WNT signaling affects gene expression in the ventral diencephalon and pituitary gland growth. Dev Dyn. (2008) 237:1006-20. doi: $10.1002 /$ dvdy.21511

35. Osmundsen AM, Keisler JL, Taketo MM, Davis SW. Canonical WNT signaling regulates the pituitary organizer and pituitary gland formation. Endocrinology. (2017) 158:3339-53. doi: 10.1210/en.2017-00581

36. Kioussi C, Briata P, Baek SH, Rose DW, Hamblet NS, Herman T, et al. Identification of a Wnt/Dvl/ $\beta$-Catenin $\rightarrow$ Pitx2 pathway mediating celltype-specific proliferation during development. Cell. (2002) 111:673-85. doi: 10.1016/S0092-8674(02)01084-X

37. Olson LE, Tollkuhn J, Scafoglio C, Krones A, Zhang J, Ohgi $\mathrm{KA}$, et al. Homeodomain-mediated $\beta$-catenin-dependent switching events dictate cell-lineage determination. Cell. (2006) 125:593-605. doi: 10.1016/j.cell.2006.02.046

38. Andoniadou CL, Signore M, Young RM, Gaston-Massuet C, Wilson SW, Fuchs E, et al. HESX1- and TCF3-mediated repression of Wnt/ -catenin targets is required for normal development of the anterior forebrain. Development. (2011) 138:4931-42. doi: 10.1242/dev.066597

39. Gaston-Massuet C, McCabe MJ, Scagliotti V, Young RM, Carreno G, Gregory LC, et al. Transcription factor 7-like 1 is involved in hypothalamo-pituitary axis development in mice and humans. Proc Natl Acad Sci USA. (2016) 113:E548-57. doi: 10.1073/pnas.1503346113

40. Brinkmeier ML, Potok MA, Cha KB, Gridley T, Stifani S, Meeldijk J, et al. TCF and groucho-related genes influence pituitary growth and development. Mol Endocrinol. (2003) 17:2152-61. doi: 10.1210/me.2003-0225

41. Brinkmeier ML, Potok MA, Davis SW, Camper SA. TCF4 deficiency expands ventral diencephalon signaling and increases induction of pituitary progenitors. Dev Biol. (2007) 311:396-407. doi: 10.1016/j.ydbio.2007.08.046

42. Cushman LJ. Persistent Prop1 expression delays gonadotrope differentiation and enhances pituitary tumor susceptibility. Hum Mol Genet. (2001) 10:1141-53. doi: $10.1093 / \mathrm{hmg} / 10.11 .1141$

43. Zhang Z, Florez S, Gutierrez-Hartmann A, Martin JF, Amendt BA. MicroRNAs regulate pituitary development, and MicroRNA 26b specifically targets lymphoid enhancer factor 1 (Lef-1), which modulates pituitary transcription factor 1 (Pit-1) expression. J Biol Chem. (2010) 285:34718-28. doi: $10.1074 /$ jbc.M110.126441

44. Buslei R, Nolde M, Hofmann B, Meissner S, Eyupoglu IY, Siebzehnrübl $F$, et al. Common mutations of $\beta$-catenin in adamantinomatous craniopharyngiomas but not in other tumours originating from the sellar region. Acta Neuropathol. (2005) 109:589-97. doi: 10.1007/s00401-005-1004-x

45. Gaston-Massuet C, Andoniadou CL, Signore M, Jayakody SA, Charolidi $\mathrm{N}$, Kyeyune R, et al. Increased Wingless (Wnt) signaling in pituitary progenitor/stem cells gives rise to pituitary tumors in mice and humans. Proc Natl Acad Sci USA. (2011) 108:11482-7. doi: 10.1073/pnas.1101553108 
46. Prince KL, Walvoord EC, Rhodes SJ. The role of homeodomain transcription factors in heritable pituitary disease. Nat Rev Endocrinol. (2011) 7:727-37. doi: 10.1038 /nrendo.2011.119

47. Dattani MT, Martinez-Barbera J-P, Thomas PQ, Brickman JM, Gupta R, Mårtensson I-L, et al. Mutations in the homeobox gene HESX1/Hesx1 associated with septo-optic dysplasia in human and mouse. Nat Genet. (1998) 19:125-33. doi: 10.1038/477

48. Dasen JS, Barbera JPM, Herman TS, O'Connell S, Olson L, Ju B, et al. Temporal regulation of a paired-like homeodomain repressor/TLE corepressor complex and a related activator is required for pituitary organogenesis. Genes Dev. (2001) 1:3193-207. doi: 10.1101/gad.932601

49. Gaston-Massuet C, Andoniadou CL, Signore M, Sajedi E, Bird S, Turner JMA, et al. Genetic interaction between the homeobox transcription factors HESX1 and SIX3 is required for normal pituitary development. Dev Biol. (2008) 324:322-33. doi: 10.1016/j.ydbio.2008.08.008

50. Li X. Tissue-specific regulation of retinal and pituitary precursor cell proliferation. Science. (2002) 297:1180-3. doi: 10.1126/science.1073263

51. Castinetti F, Brinkmeier ML, Gordon DF, Vella KR, Kerr JM, Mortensen $\mathrm{AH}$, et al. PITX2 AND PITX1 regulate thyrotroph function and response to hypothyroidism. Mol Endocrinol. (2011) 25:1950-60. doi: 10.1210/me.2010-0388

52. Zhao Y, Mailloux CM, Hermesz E, Palkóvits M, Westphal H. A role of the LIM-homeobox gene Lhx2 in the regulation of pituitary development. Dev Biol. (2010) 337:313-23. doi: 10.1016/j.ydbio.2009.11.002

53. Sheng HZ, Moriyama K, Yamashita T, Li H, Potter SS, Mahon KA, et al. Multistep control of pituitary organogenesis. Science. (1997) 278:1809-12. doi: 10.1126/science.278.5344.1809

54. Lee B, Rizzoti K, Kwon DS, Kim S-Y, Oh S, Epstein DJ, et al. Direct transcriptional regulation of Six6 is controlled by SoxB1 binding to a remote forebrain enhancer. Dev Biol. (2012) 366:393-403. doi: 10.1016/j.ydbio.2012.04.023

55. Lee B, Song H, Rizzoti K, Son Y, Yoon J, Baek K, et al. Genomic code for Sox2 binding uncovers its regulatory role in Six3 activation in the forebrain. Dev Biol. (2013) 381:491-501. doi: 10.1016/j.ydbio.2013.06.016

56. Laumonnier F, Ronce N, Hamel BCJ, Thomas P, Lespinasse J, Raynaud M, et al. Transcription factor SOX3 is involved in X-linked mental retardation with growth hormone deficiency. Am J Hum Genet. (2002) 71:1450-5. doi: $10.1086 / 344661$

57. Kelberman D, Rizzoti K, Avilion A, Bitner-Glindzicz M, Cianfarani S, Collins J, et al. Mutations within Sox2/SOX2 are associated with abnormalities in the hypothalamo-pituitary-gonadal axis in mice and humans. J Clin Invest. (2006) 116:2442-55. doi: 10.1172/JCI28658

58. Rizzoti K, Brunelli S, Carmignac D, Thomas PQ, Robinson IC, Lovell-Badge R. SOX3 is required during the formation of the hypothalamo-pituitary axis. Nat Genet. (2004) 36:247-55. doi: 10.1038/ng1309

59. Gage PJ, Brinkmeier ML, Scarlett LM, Knapp LT, Camper SA, Mahon KA. The Ames dwarf gene, df, is required early in pituitary ontogeny for the extinction of Rpx transcription and initiation of lineage-specific cell proliferation. Mol Endocrinol. (1996) 10:1570-81. doi: 10.1210/mend.10.12.8961267

60. Sornson MW, Wu W, Dasen JS, Flynn SE, Norman DJ, O'Connell $\mathrm{SM}$, et al. Pituitary lineage determination by the Prophet of Pit-1 homeodomain factor defective in Ames dwarfism. Nature. (1996) 384:32733. doi: $10.1038 / 384327 \mathrm{a} 0$

61. Yoshida S, Kato T, Susa T, Cai L, Nakayama M, Kato Y. PROP1 coexists with SOX2 and induces PIT1-commitment cells. Biochem Biophys Res Commun. (2009) 385:11-5. doi: 10.1016/j.bbrc.2009.05.027

62. Nasonkin IO, Ward RD, Raetzman LT, Seasholtz AF, Saunders TL, Gillespie PJ, et al. Pituitary hypoplasia and respiratory distress syndrome in Prop1 knockout mice. Hum Mol Genet. (2004) 13:2727-35. doi: 10.1093/hmg/ddh311

63. Pérez Millán MI, Brinkmeier ML, Mortensen AH, Camper SA. PROP1 triggers epithelial-mesenchymal transition-like process in pituitary stem cells. Elife. (2016)5:e14470. doi: 10.7554/eLife.14470

64. Ward RD, Raetzman LT, Suh H, Stone BM, Nasonkin IO, Camper SA. Role of PROP1 in pituitary gland growth. Mol Endocrinol. (2005) 19:698-710. doi: 10.1210/me.2004-0341
65. Wang $\mathrm{X}$, Zheng $\mathrm{M}$, Liu G, Xia W, McKeown-Longo PJ, Hung MC, et al. Krüppel-like factor 8 induces epithelial to mesenchymal transition and epithelial cell invasion. Cancer Res. (2007) 67:7184-93. doi: 10.1158/0008-5472.CAN-06-4729

66. Welcker JE, Hernandez-Miranda LR, Paul FE, Jia S, Ivanov A, Selbach M, et al. Insm 1 controls development of pituitary endocrine cells and requires a SNAG domain for function and for recruitment of histone-modifying factors. Development. (2013) 140:4947-58. doi: 10.1242/dev.097642

67. Li S, Crenshaw EB, Rawson EJ, Simmons DM, Swanson LW, Rosenfeld MG. Dwarf locus mutants lacking three pituitary cell types result from mutations in the POU-domain gene pit-1. Nature. (1990) 347:528-33. doi: $10.1038 / 347528 \mathrm{a} 0$

68. Ward RD, Stone BM, Raetzman LT, Camper SA. Cell proliferation and vascularization in mouse models of pituitary hormone deficiency. $\mathrm{Mol}$ Endocrinol. (2006) 20:1378-90. doi: 10.1210/me.2005-0409

69. Cheung LYM, Rizzoti K, Lovell-Badge R, Le Tissier PR. Pituitary phenotypes of mice lacking the notch signalling ligand delta-like 1 homologue. $J$ Neuroendocrinol. (2013) 25:391-401. doi: 10.1111/jne.12010

70. Featherstone K, White MRH, Davis JRE. The prolactin gene: a paradigm of tissue-specific gene regulation with complex temporal transcription dynamics. J Neuroendocrinol. (2012) 24:977-90. doi: 10.1111/j.1365-2826.2012.02310.x

71. Dasen JS, O'Connell SM, Flynn SE, Treier M, Gleiberman AS, Szeto DP, et al.. Reciprocal interactions of Pit1 and GATA2 mediate signaling gradient-induced determination of pituitary cell types. Cell. (1999) 97:58798. doi: 10.1016/S0092-8674(00)80770-9

72. Wen S, Ai W, Alim Z, Boehm U. Embryonic gonadotropin-releasing hormone signaling is necessary for maturation of the male reproductive axis. Proc Natl Acad Sci USA. (2010) 107:16372-7. doi: 10.1073/pnas.1000423107

73. Fortin J, Lamba P, Wang Y, Bernard DJ. Conservation of mechanisms mediating gonadotrophin-releasing hormone 1 stimulation of human luteinizing hormone $\beta$ subunit transcription. MHR Basic Sci Reprod Med. (2009) 15:77-87. doi: 10.1093/molehr/gan079

74. Pulichino A-M. Human and mouse TPIT gene mutations cause early onset pituitary ACTH deficiency. Genes Dev. (2003) 17:711-6. doi: $10.1101 /$ gad. 1065603

75. Pulichino AM, Vallette-Kasic S, Tsai JPY, Couture C, Gauthier Y, Drouin J. Tpit determines alternate fates during pituitary cell differentiation. Genes Dev. (2003) 17:738-47. doi: 10.1101/gad.1065703

76. Lavoie P-L, Budry L, Balsalobre A, Drouin J. Developmental dependence on NurRE and ebox neuro for expression of pituitary proopiomelanocortin. $\mathrm{Mol}$ Endocrinol. (2008) 22:1647-57. doi: 10.1210/me.2007-0567

77. Budry L, Balsalobre A, Gauthier Y, Khetchoumian K, L'Honoré A, Vallette $\mathrm{S}$, et al. The selector gene Pax7 dictates alternate pituitary cell fates through its pioneer action on chromatin remodeling. Genes Dev. (2012) 26:2299-310. doi: $10.1101 / \mathrm{gad} .200436 .112$

78. Andoniadou CL. Pituitary stem cells during normal physiology and disease. In: Pfaff D, Christen Y, editors. Stem Cells in Neuroendocrinology. Cham: Springer (2016). p. 103-11. doi: 10.1007/978-3-319-41603-8_8

79. Martinez-Barbera JP, Andoniadou CL. Concise review: paracrine role of stem cells in pituitary tumors: a focus on adamantinomatous craniopharyngioma. Stem Cells. (2016) 34:268-76. doi: 10.1002/stem.2267

80. Mertens F, Gremeaux L, Chen J, Fu Q, Willems C, Roose H, et al. Pituitary tumors contain a side population with tumor stem cellassociated characteristics. Endocr Relat Cancer. (2015) 22:481-504. doi: 10.1530/ERC-14-0546

81. Vankelecom H, Chen J. Pituitary stem cells: where do we stand? Mol Cell Endocrinol. (2014) 385:2-17. doi: 10.1016/j.mce.2013.08.018

82. Vankelecom H. Pituitary stem /progenitor cells: embryonic players in the adult gland? Eur J Neurosci. (2010) 32:2063-81. doi: 10.1111/j.1460-9568.2010.07523.x

83. Vankelecom H. Pituitary stem cells: quest for hidden functions. In: Pfaff D, Christen Y, editors. Stem Cells in Neuroendocrinology. Cham: Springer (2016). p. 81-101. doi: 10.1007/978-3-319-41603-8_7

84. Goldsmith S, Lovell-Badge R, Rizzoti K. SOX2 is sequentially required for progenitor proliferation and lineage specification in the developing pituitary. Development. (2016) 143:2376-88. doi: 10.1242/dev.137984 
85. Rizzoti K, Akiyama H, Lovell-Badge R. Mobilized adult pituitary stem cells contribute to endocrine regeneration in response to physiological demand. Cell Stem Cell. (2013) 13:419-32. doi: 10.1016/j.stem.2013.07.006

86. Davis SW, Ellsworth BS, Peréz Millan MI, Gergics P, Schade V, Foyouzi N, et al. Pituitary gland development and disease: from stem cell to hormone production. Curr Top Dev Biol. 106:1-47. doi: 10.1016/B978-0-12-416021-7.00001-8

87. Jayakody SA, Andoniadou CL, Gaston-Massuet C, Signore M, Cariboni A, Bouloux PM, et al. SOX2 regulates the hypothalamic-pituitary axis at multiple levels. J Clin Invest. (2012) 122:3635-46. doi: 10.1172/ JCI64311

88. Mollard P, Hodson DJ, Lafont C, Rizzoti K, Drouin J. A tridimensional view of pituitary development and function. Trends Endocrinol Metab. (2012) 23:261-9. doi: 10.1016/j.tem.2012.02.004

89. Andoniadou CL, Matsushima D, Mousavy Gharavy SN, Signore M, Mackintosh AI, Schaeffer M, et al. Sox2+ stem/progenitor cells in the adult mouse pituitary support organ homeostasis and have tumor-inducing potential. Cell Stem Cell. (2013) 13:433-45. doi: 10.1016/j.stem.2013.07.004

90. Roose H, Cox B, Boretto M, Gysemans C, Vennekens A, Vankelecom H. Major depletion of SOX2 + stem cells in the adult pituitary is not restored which does not affect hormonal cell homeostasis and remodelling. Sci Rep. (2017) 7:16940. doi: 10.1038/s41598-017-16796-2

91. Bonnefont X, Lacampagne A, Sanchez-Hormigo A, Fino E, Creff A, Mathieu $\mathrm{M}-\mathrm{N}$, et al. Revealing the large-scale network organization of growth hormone-secreting cells. Proc Natl Acad Sci USA. (2005) 102:16880-5. doi: 10.1073/pnas.0508202102

92. Suga H, Kadoshima T, Minaguchi M, Ohgushi M, Soen M, Nakano T, et al. Self-formation of functional adenohypophysis in three-dimensional culture. Nature. (2011) 480:57-62. doi: 10.1038/nature10637

93. Ozone C, Suga H, Eiraku M, Kadoshima T, Yonemura S, Takata $\mathrm{N}$, et al. Functional anterior pituitary generated in self-organizing culture of human embryonic stem cells. Nat Commun. (2016) 7:10351. doi: $10.1038 /$ ncomms 10351

94. Dincer Z, Piao J, Niu L, Ganat Y, Kriks S, Zimmer B, et al. Specification of functional cranial placode derivatives from human pluripotent stem cells. Cell Rep. (2013) 5:1387-402. doi: 10.1016/j.celrep.2013.10.048

95. Cox B, Laporte E, Vennekens A, Kobayashi H, Nys C, Van Zundert I, et al. Organoids from pituitary as a novel research model toward pituitary stem cell exploration. J Endocrinol. (2019) 240:287-308. doi: 10.1530/JOE-18-0462

96. Parker KL, Schimmer BP. Steroidogenic factor 1: a key determinant of endocrine development and function. Endocr Rev. (1997) 18:361-77. doi: 10.1210/er.18.3.361

97. Val P, Martinez-Barbera J-P, Swain A. Adrenal development is initiated by Cited 2 and Wt1 through modulation of Sf-1 dosage. Development. (2007) 134:2349-58. doi: 10.1242/dev.004390

98. Wood MA, Acharya A, Finco I, Swonger JM, Elston MJ, Tallquist MD, Hammer GD. Fetal adrenal capsular cells serve as progenitor cells for steroidogenic and stromal adrenocortical cell lineages in M. musculus. Development. (2013) 140:4522-32. doi: 10.1242/dev.092775

99. Walczak EM, Hammer GD. Regulation of the adrenocortical stem cell niche: implications for disease. Nat Rev Endocrinol. (2015) 11:14-28. doi: 10.1038/nrendo.2014.166

100. King P, Paul A, Laufer E. Shh signaling regulates adrenocortical development and identifies progenitors of steroidogenic lineages. Proc Natl Acad Sci USA. (2009) 106:21185-90. doi: 10.1073/pnas.0909471106

101. Huang C-CJ, Miyagawa S, Matsumaru D, Parker KL, Yao HH-C. Progenitor cell expansion and organ size of mouse adrenal is regulated by sonic hedgehog. Endocrinology. (2010) 151:1119-28. doi: 10.1210/en.2009-0814

102. Guasti L, Paul A, Laufer E, King P. Localization of Sonic hedgehog secreting and receiving cells in the developing and adult rat adrenal cortex. Mol Cell Endocrinol. (2011) 336:117-22. doi: 10.1016/j.mce.2010.11.010

103. Finco I, Lerario AM, Hammer GD. Sonic hedgehog and WNT signaling promote adrenal gland regeneration in male mice. Endocrinology. (2018) 159:579-96. doi: 10.1210/en.2017-03061

104. Guasti L, Cavlan D, Cogger K, Banu Z, Shakur A, Latif S, et al. Dlk1 up-regulates Glil expression in male rat adrenal capsule cells through the activation of $\beta 1$ integrin and ERK1/2. Endocrinology. (2013) 154:4675-84. doi: $10.1210 /$ en.2013-1211
105. Guasti L, Candy Sze WC, McKay T, Grose R, King PJ. FGF signalling through Fgfr2 isoform IIIb regulates adrenal cortex development. Mol Cell Endocrinol. (2013) 371:182-8. doi: 10.1016/j.mce.2013.01.014

106. Halder SK, Takemori H, Hatano O, Nonaka Y, Wada A, Okamoto M. Cloning of a membrane-spanning protein with epidermal growth factor- like repeat motifs from adrenal glomerulosa cells. Endocrinology. (1998) 139:3316-28. doi: 10.1210/endo.139.7.6081

107. Hudak CS, Sul HS. Pref-1, a gatekeeper of adipogenesis. Front Endocrinol. (2013) 4:1-6. doi: 10.3389/fendo.2013.00079

108. Hadjidemetriou I, Mariniello K, Ruiz-Babot G, Pittaway J, Mancini A, Mariannis D, et al. DLK1/PREF1 marks a novel cell population in the human adrenal cortex. J Steroid Biochem Mol Biol. (2019) 193:105422. doi: 10.1016/j.jsbmb.2019.105422

109. Heikkilä M, Peltoketo H, Leppäluoto J, Ilves $M$, Vuolteenaho O, Vainio S. Wnt-4 deficiency alters mouse adrenal cortex function, reducing aldosterone production. Endocrinology. (2002) 143:4358-65. doi: 10.1210/en.2002-220275

110. Freedman BD, Kempna PB, Carlone DL, Shah MS, Guagliardo NA, Barrett PQ, et al. Adrenocortical zonation results from lineage conversion of differentiated zona glomerulosa cells. Dev Cell. (2013) 26:666-73. doi: 10.1016/j.devcel.2013.07.016

111. Kim AC, Reuter AL, Zubair M, Else T, Serecky K, Bingham NC, et al. Targeted disruption of beta-catenin in Sf1-expressing cells impairs development and maintenance of the adrenal cortex. Development. (2008) 135:2593-602. doi: 10.1242/dev.021493

112. Berthon A, Sahut-Barnola I, Lambert-Langlais S, de Joussineau C, DamonSoubeyrand C, Louiset E, et al. Constitutive $\beta$-catenin activation induces adrenal hyperplasia and promotes adrenal cancer development. Hum Mol Genet. (2010) 19:1561-76. doi: 10.1093/hmg/ddq029

113. Walczak EM, Kuick R, Finco I, Bohin N, Hrycaj SM, Wellik DM, et al. Wnt signaling inhibits adrenal steroidogenesis by cell-autonomous and non-cell-autonomous mechanisms. Mol Endocrinol. (2014) 28:1471-86. doi: 10.1210/me.2014-1060

114. Vidal V, Sacco S, Rocha AS, da Silva F, Panzolini C, Dumontet T, et al. The adrenal capsule is a signaling center controlling cell renewal and zonation through Rspo3. Genes Dev. (2016) 30:1389-94. doi: 10.1101/gad.277756.116

115. Drelon C, Berthon A, Sahut-Barnola I, Mathieu M, Dumontet T, Rodriguez $\mathrm{S}$, et al. PKA inhibits WNT signalling in adrenal cortex zonation and prevents malignant tumour development. Nat Commun. (2016) 7:12751. doi: 10.1038/ncomms12751

116. Dumontet T, Sahut-Barnola I, Septier A, Montanier N, Plotton I, RoucherBoulez F, et al. PKA signaling drives reticularis differentiation and sexually dimorphic adrenal cortex renewal. JCI Insight. (2018) 3:e98394. doi: 10.1172/jci.insight.98394

117. Grabek A, Dolfi B, Klein B, Jian-Motamedi F, Chaboissier M-C, Schedl A. The adult adrenal cortex undergoes rapid tissue renewal in a sex-specific manner. Cell Stem Cell. (2019) 25:290-6.e2. doi: 10.1016/j.stem.2019.04.012

118. Drelon C, Berthon A, Mathieu M, Ragazzon B, Kuick R, Tabbal $\mathrm{H}$, et al. EZH2 is overexpressed in adrenocortical carcinoma and is associated with disease progression. Hum Mol Genet. (2016) 25:2789-800. doi: $10.1093 / \mathrm{hmg} / \mathrm{ddw} 136$

119. Assié G, Letouzé E, Fassnacht M, Jouinot A, Luscap W, Barreau O, et al. Integrated genomic characterization of adrenocortical carcinoma. Nat Genet. (2014) 46:607-12. doi: 10.1038/ng.2953

120. Mathieu M, Drelon C, Rodriguez S, Tabbal H, Septier A, Damon-Soubeyrand $\mathrm{C}$, et al. Steroidogenic differentiation and PKA signaling are programmed by histone methyltransferase EZH2 in the adrenal cortex. Proc Natl Acad Sci USA. (2018) 115:E12265-74. doi: 10.1073/pnas.1809185115

121. Basham KJ, Rodriguez S, Turcu AF, Lerario AM, Logan CY, Rysztak $\mathrm{MR}$, et al. A ZNRF3-dependent Wnt / $\beta$-catenin signaling gradient is required for adrenal homeostasis. Genes Dev. (2019) 33:209-20. doi: $10.1101 / \operatorname{gad} .317412 .118$

122. Crawford PA, Sadovsky Y, Milbrandt J. Nuclear receptor steroidogenic factor 1 directs embryonic stem cells toward the steroidogenic lineage. Mol Cell Biol. (1997) 17:3997-4006. doi: 10.1128/MCB.17.7.3997

123. Ruiz-Babot G, Hadjidemetriou I, King PJ, Guasti L. New directions for the treatment of adrenal insufficiency. Front Endocrinol. (2015) 6:70. doi: $10.3389 /$ fendo. 2015.00070 
124. Ruiz-Babot G, Balyura M, Hadjidemetriou I, Ajodha SJ, Taylor DR, Ghataore $\mathrm{L}$, et al. Modeling congenital adrenal hyperplasia and testing interventions for adrenal insufficiency using donor-specific reprogrammed cells. Cell Rep. (2018) 22:1236-49. doi: 10.1016/j.celrep.2018.01.003

125. Huber K, Kalcheim C, Unsicker K. The development of the chromaffin cell lineage from the neural crest. Auton Neurosci. (2009) 151:10-6. doi: 10.1016/j.autneu.2009.07.020

126. Saito D, Takase Y, Murai H, Takahashi Y. The dorsal aorta initiates a molecular cascade that instructs sympatho-adrenal specification. Science. (2012) 336:1578-81. doi: 10.1126/science.1222369

127. Furlan A, Dyachuk V, Kastriti ME, Calvo-Enrique L, Abdo H, Hadjab S, et al. Multipotent peripheral glial cells generate neuroendocrine cells of the adrenal medulla. Science. (2017) 357:eaal3753. doi: 10.1126/science.aal3753

128. Dyachuk V, Furlan A, Shahidi MK, Giovenco M, Kaukua N, Konstantinidou $\mathrm{C}$, et al. Parasympathetic neurons originate from nerve-associated peripheral glial progenitors. Science. (2014) 345:82-7. doi: 10.1126/science.1253281

129. Espinosa-Medina I, Outin E, Picard CA, Chettouh Z, Dymecki S, Consalez GG, et al. Parasympathetic ganglia derive from Schwann cell precursors. Science. (2014) 345:87-90. doi: 10.1126/science.1253286

130. Joseph NM. Neural crest stem cells undergo multilineage differentiation in developing peripheral nerves to generate endoneurial fibroblasts in addition to Schwann cells. Development. (2004) 131:5599-12. doi: 10.1242/dev.01429

131. Adameyko I, Lallemend F, Aquino JB, Pereira JA, Topilko P, Müller T, et al. Schwann cell precursors from nerve innervation are a cellular origin of melanocytes in skin. Cell. (2009) 139:366-79. doi: 10.1016/j.cell.2009. 07.049

132. Kaukua N, Shahidi MK, Konstantinidou C, Dyachuk V, Kaucka M, Furlan A, et al. Glial origin of mesenchymal stem cells in a tooth model system. Nature. (2014) 513:551-4. doi: 10.1038/nature13536

133. Krispin S, Nitzan E, Kassem Y, Kalcheim C. Evidence for a dynamic spatiotemporal fate map and early fate restrictions of premigratory avian neural crest. Development. (2010) 137:585-95. doi: 10.1242/dev.0 41509

134. Shtukmaster S, Schier M, Huber K, Krispin S, Kalcheim C, Unsicker K. Sympathetic neurons and chromaffin cells share a common progenitor in the neural crest in vivo. Neural Dev. (2013) 8:12. doi: 10.1186/1749-8104-8-12

135. Chung K-F, Sicard F, Vukicevic V, Hermann A, Storch A, Huttner WB, et al. Isolation of neural crest derived chromaffin progenitors from adult adrenal medulla. Stem Cells. (2009) 27:2602-13. doi: 10.1002/stem.180

136. Santana MM, Chung K-F, Vukicevic V, Rosmaninho-Salgado J, Kanczkowski $\mathrm{W}$, Cortez V, et al. Isolation, characterization, and differentiation of progenitor cells from human adult adrenal medulla. Stem Cells Transl Med. (2012) 1:783-91. doi: 10.5966/sctm.2012-0022

137. Rubin de Celis MF, Garcia-Martin R, Wittig D, Valencia GD, Enikolopov G, Funk RH, et al. Multipotent glia-like stem cells mediate stress adaptation. Stem Cells. (2015) 33:2037-51. doi: 10.1002/stem.2002

138. Abu-Bonsrah KD, Zhang D, Bjorksten AR, Dottori M, Newgreen DF. Generation of adrenal chromaffin-like cells from human pluripotent stem cells. Stem Cell Rep. (2018) 10:134-50. doi: 10.1016/j.stemcr.2017. 11.003

139. Le Douarin N, Le Lièvre C. [Demonstration of neural origin of calcitonin cells of ultimobranchial body of chick embryo]. C R Acad Sci Hebd Seances Acad Sci D. (1970) 270:2857-60.

140. Polak JM, Pearse AGE, Le Lièvre C, Fontaine J, Le Douarin NM. Immunocytochemical confirmation of the neural crest origin of avian calcitonin-producing cells. Histochemistry. (1974) 40:209-14. doi: 10.1007/BF00501955

141. Johansson E, Andersson L, Örnros J, Carlsson T, Ingeson-Carlsson C, Liang $\mathrm{S}$, et al. Revising the embryonic origin of thyroid C cells in mice and humans. Development. (2015) 142:3519-28. doi: 10.1242/dev.126581

142. Le Douarin N, Fontaine J, Le Lièvre C. New studies on the neural crest origin of the avian ultimobranchial glandular cells-interspecific combinations and cytochemical characterization of C cells based on the uptake of biogenic amine precursors. Histochemistry. (1974) 38:297-305. doi: 10.1007/BF00496718

143. Fontaine J. Multistep migration of calcitonin cell precursors during ontogeny of the mouse pharynx. Gen Comp Endocrinol. (1979) 37:81-92. doi: 10.1016/0016-6480(79)90049-2
144. Szinnai G, Lacroix L, Carré A, Guimiot F, Talbot M, Martinovic J, et al. Sodium/Iodide Symporter (NIS) gene expression is the limiting step for the onset of thyroid function in the human fetus. J Clin Endocrinol Metab. (2007) 92:70-6. doi: 10.1210/jc.2006-1450

145. Parlato R, Rosica A, Rodriguez-Mallon A, Affuso A, Postiglione MP, Arra C, et al. An integrated regulatory network controlling survival and migration in thyroid organogenesis. Dev Biol. (2004) 276:464-75. doi: 10.1016/j.ydbio.2004.08.048

146. Fernández LP, López-Márquez A, Santisteban P. Thyroid transcription factors in development, differentiation and disease. Nat Rev Endocrinol. (2015) 11:29-42. doi: 10.1038/nrendo.2014.186

147. Kimura S, Hara Y, Pineau T, Fernandez-Salguero P, Fox CH, Ward JM, et al. The T/ebp null mouse: thyroid-specific enhancer-binding protein is essential for the organogenesis of the thyroid, lung, ventral forebrain, and pituitary. Genes Dev. (1996) 10:60-9. doi: 10.1101/gad.10.1.60

148. Clifton-Bligh RJ, Wentworth JM, Heinz P, Crisp MS, John R, Lazarus JH, et al. Mutation of the gene encoding human TTF-2 associated with thyroid agenesis, cleft palate and choanal atresia. Nat Genet. (1998) 19:399-401. doi: $10.1038 / 1294$

149. De Felice M, Ovitt C, Biffali E, Rodriguez-Mallon A, Arra C, Anastassiadis K, et al. A mouse model for hereditary thyroid dysgenesis and cleft palate. Nat Genet. (1998) 19:395-8. doi: 10.1038/1289

150. Mansouri A, Chowdhury K, Gruss P. Follicular cells of the thyroid gland require Pax8 gene function. Nat Genet. (1998) 19:87-90. doi: 10.1038/ng0598-87

151. Martinez Barbera JP, Clements M, Thomas P, Rodriguez T, Meloy D, Kioussis $\mathrm{D}$, et al. The homeobox gene Hex is required in definitive endodermal tissues for normal forebrain, liver and thyroid formation. Development. (2000) 127:2433-45.

152. Kimura S, Ward JM, Minoo P. Thyroid-specific enhancer-binding protein/thyroid transcription factor 1 is not required for the initial specification of the thyroid and lung primordia. Biochimie. (1999) 81:321-7. doi: 10.1016/S0300-9084(99)80077-7

153. Doniach I. Proceedings: experimental evidence of etiology of thyroid cancer. Proc R Soc Med. (1974) 67:1103. doi: 10.1177/0035915774067 01106

154. Coclet J, Foureau F, Ketelbant P, Galand P, Dumont JE. Cell population kinetics in dog and human adult thyroid. Clin Endocrinol. (1989) 31:655-66. doi: 10.1111/j.1365-2265.1989.tb01290.x

155. Dumont JE, Lamy F, Roger P, Maenhaut C. Physiological and pathological regulation of thyroid cell proliferation and differentiation by thyrotropin and other factors. Physiol Rev. (2017) 72:667-97. doi: 10.1152/physrev.1992.72.3.667

156. Hoshi N, Kusakabe T, Taylor BJ, Kimura S. Side population cells in the mouse thyroid exhibit stem/progenitor cell-like characteristics. Endocrinology. (2007) 148:4251-8. doi: 10.1210/en.2006-0490

157. Thomas T, Nowka K, Lan L, Derwahl M. Expression of endoderm stem cell markers: evidence for the presence of adult stem cells in human thyroid glands. Thyroid. (2006) 16:537-44. doi: 10.1089/thy.2006.16.537

158. Lan L, Cui D, Nowka K, Derwahl M. Stem cells derived from goiters in adults form spheres in response to intense growth stimulation and require thyrotropin for differentiation into thyrocytes. J Clin Endocrinol Metab. (2007) 92:3681-8. doi: 10.1210/jc.2007-0281

159. Fierabracci A, Puglisi MA, Giuliani L, Mattarocci S, Gallinella-Muzi M. Identification of an adult stem/progenitor cell-like population in the human thyroid. J Endocrinol. (2008) 198:471-87. doi: 10.1677/JOE-07-0552

160. Revest J-M, Spencer-Dene B, Kerr K, De Moerlooze L, Rosewell I, Dickson C. Fibroblast growth factor receptor 2-IIIb acts upstream of Shh and Fgf4 and is required for limb bud maintenance but not for the induction of Fgf8, Fgf10, Msx1, or Bmp4. Dev Biol. (2001) 231:47-62. doi: 10.1006/dbio.2000.0144

161. Ohuchi H, Hori Y, Yamasaki M, Harada H, Sekine K, Kato S, et al. FGF10 acts as a major ligand for FGF receptor 2 IIIb in mouse multiorgan development. Biochem Biophys Res Commun. (2000) 277:643-9. doi: 10.1006/bbrc.2000.3721

162. Wendl T, Adzic D, Schoenebeck JJ, Scholpp S, Brand M, Yelon D, et al. Early developmental specification of the thyroid gland depends on han-expressing surrounding tissue and on FGF signals. Development. (2007) 134:2871-9. doi: $10.1242 /$ dev.02872 
163. Longmire TA, Ikonomou L, Hawkins F, Christodoulou C, Cao Y, Jean JC, et al. Efficient derivation of purified lung and thyroid progenitors from embryonic stem cells. Cell Stem Cell. (2012) 10:398-411. doi: $10.1016 /$ j.stem.2012.01.019

164. Ozaki T, Matsubara T, Seo D, Okamoto M, Nagashima K, Sasaki $\mathrm{Y}$, et al. Thyroid regeneration: characterization of clear cells after partial thyroidectomy. Endocrinology. (2012) 153:2514-25. doi: 10.1210/en.2011-1365

165. Arufe MC, Lu M, Kubo A, Keller G, Davies TF, Lin R-Y. Directed differentiation of mouse embryonic stem cells into thyroid follicular cells. Endocrinology. (2006) 147:3007-15. doi: 10.1210/en.2005-1239

166. Zhang P, Zuo H, Ozaki T, Nakagomi N, Kakudo K. Cancer stem cell hypothesis in thyroid cancer. Pathol Int. (2006) 56:485-9. doi: $10.1111 / j .1440-1827.2006 .01995 . x$

167. Liao H, Dumitrescu AM, Refetoff S, Peremans K, Antonica F, Kasprzyk DF, et al. Generation of functional thyroid from embryonic stem cells. Nature. (2012) 491:66-71. doi: 10.1038/nature11525

168. Kurmann AA, Serra M, Hawkins F, Rankin SA, Mori M, Astapova I, et al. Regeneration of thyroid function by transplantation of differentiated pluripotent stem cells. Cell Stem Cell. (2015) 17:527-42. doi: 10.1016/j.stem.2015.09.004

169. Arauchi A, Matsuura K, Shimizu T, Okano T. Functional thyroid follicular cells differentiation from human-induced pluripotent stem cells in suspension culture. Front Endocrinol. (2017) 8:103. doi: $10.3389 /$ fendo.2017.00103

170. Antonica F. Generation of functional thyroid from embryonic stem cells. In: Thyroid Diseases in Childhood: Recent Advances from Basic Science to Clinical Practice. Cham: Springer International Publishing. p. 217-230. doi: 10.1007/978-3-319-19213-0_19

171. Weller GL. Development of the thyroid, parathyroid and thymus glands in man. Embryol Carnegie Inst Wash. (1933) 24:93-139.

172. Gordon J, Patel SR, Mishina Y, Manley NR. Evidence for an early role for BMP4 signaling in thymus and parathyroid morphogenesis. Dev Biol. (2010) 339:141-54. doi: 10.1016/j.ydbio.2009.12.026

173. Foster KE, Gordon J, Cardenas K, Veiga-Fernandes H, Makinen T, Grigorieva E, et al. EphB-ephrin-B2 interactions are required for thymus migration during organogenesis. Proc Natl Acad Sci USA. (2010) 107:134149. doi: 10.1073/pnas.1003747107

174. Günther T, Chen Z-F, Kim J, Priemel M, Rueger JM, Amling M, et al. Genetic ablation of parathyroid glands reveals another source of parathyroid hormone. Nature. (2000) 406:199-203. doi: 10.1038/35018111

175. Mitsui T, Narumi S, Inokuchi M, Nagasaki K, Nakazawa M, Sasaki $\mathrm{G}$, et al. Comprehensive next-generation sequencing analyses of hypoparathyroidism: identification of novel GCM2 mutations. J Clin Endocrinol Metab. (2014) 99:E2421-8. doi: 10.1210/jc.201 4-2174

176. Guan B, Welch JM, Sapp JC, Ling H, Li Y, Johnston JJ, et al. GCM2 Activating mutations in familial isolated hyperparathyroidism. Am J Hum Genet. (2016) 99:1034-44. doi: 10.1016/j.ajhg.2016.08.018

177. Moore-Scott BA, Manley NR. Differential expression of Sonic hedgehog along the anterior-posterior axis regulates patterning of pharyngeal pouch endoderm and pharyngeal endoderm-derived organs. Dev Biol. (2005) 278:323-35. doi: 10.1016/j.ydbio.2004.10.027

178. Grevellec A, Graham A, Tucker AS. Shh signalling restricts the expression of $\mathrm{Gcm} 2$ and controls the position of the developing parathyroids. Dev Biol. (2011) 353:194-205. doi: 10.1016/j.ydbio.2011.02.012

179. Manley NR, Selleri L, Brendolan A, Gordon J, Cleary ML. Abnormalities of caudal pharyngeal pouch development in Pbx1 knockout mice mimic loss of Hox3 paralogs. Dev Biol. (2004) 276:301-12. doi: 10.1016/j.ydbio.2004.08.030

180. Bain VE, Gordon J, O’Neil JD, Ramos I, Richie ER, Manley NR. Tissue-specific roles for sonic hedgehog signaling in establishing thymus and parathyroid organ fate. Development. (2016) 143:4027-37. doi: 10.1242/dev.141903

181. Shih Y-RV, Kuo TK, Yang A-H, Lee OK, Lee C-H. Isolation and characterization of stem cells from the human parathyroid gland. Cell Prolif. (2009) 42:461-70. doi: 10.1111/j.1365-2184.2009.00614.x
182. Arnold A, Brown MF, Ureña P, Gaz RD, Sarfati E, Drüeke TB. Monoclonality of parathyroid tumors in chronic renal failure and in primary parathyroid hyperplasia. J Clin Invest. (1995) 95:2047-53. doi: 10.1172/JCI117890

183. Arnold A, Shattuck TM, Mallya SM, Krebs LJ, Costa J, Gallagher J, et al. Molecular pathogenesis of primary hyperparathyroidism. J Bone Miner Res. (2002) 17(Suppl. 2):N30-6.

184. Fang SH, Guidroz JA, O’Malley Y, Lal G, Sugg SL, Howe JR, et al. Expansion of a cell population expressing stem cell markers in parathyroid glands from patients with hyperparathyroidism. Ann Surg. (2010) 251:107-13. doi: 10.1097/SLA.0b013e3181b5da28

185. Bingham EL, Cheng S-P, Woods Ignatoski KM, Doherty GM. Differentiation of human embryonic stem cells to a parathyroid-like phenotype. Stem Cells Dev. (2009) 18:1071-80. doi: 10.1089/scd.2008.0337

186. Lawson KA, Dunn NR, Roelen BAJ, Zeinstra LM, Davis AM, Wright CVE, et al. Bmp4 is required for the generation of primordial germ cells in the mouse embryo. Genes Dev. (1999) 13:424-36. doi: 10.1101/gad.13.4.424

187. Ying Y, Zhao G-Q. Cooperation of endoderm-derived BMP2 and extraembryonic ectoderm-derived BMP4 in primordial germ cell generation in the mouse. Dev Biol. (2001) 232:484-92. doi: 10.1006/dbio.2001.0173

188. Smith P, Wilhelm D, Rodgers RJ. Development of mammalian ovary. $J$ Endocrinol. (2014) 221:R145-61. doi: 10.1530/JOE-14-0062

189. Wilhelm D, Palmer S, Koopman P. Sex determination and gonadal development in mammals. Physiol Rev. (2007) 87:1-28. doi: 10.1152/physrev.00009.2006

190. Byskov AG. Differentiation of mammalian embryonic gonad. Physiol Rev. (1986) 66:71-117. doi: 10.1152/physrev.1986.66.1.71

191. Garcia TX, DeFalco T, Capel B, Hofmann M-C. Constitutive activation of NOTCH1 signaling in Sertoli cells causes gonocyte exit from quiescence. Dev Biol. (2013) 377:188-201. doi: 10.1016/j.ydbio.2013.01.031

192. Phillips BT, Gassei K, Orwig KE. Spermatogonial stem cell regulation and spermatogenesis. Philos Trans R Soc B Biol Sci. (2010) 365:1663-78. doi: 10.1098/rstb.2010.0026

193. Brennan J, Capel B. One tissue, two fates: molecular genetic events that underlie testis versus ovary development. Nat Rev Genet. (2004) 5:509-21. doi: $10.1038 / \operatorname{nrg} 1381$

194. Albrecht KH, Eicher EM. Direct evidence that Sry is expressed in pre-Sertoli cells and that Sertoli and granulosa cells develop from a common precursor. Dev Biol. (2001) 240:92-107. doi: 10.1006/dbio.2001.0438

195. Palmer SJ, Burgoyne PS. In situ analysis of fetal, prepuberal and adult $\mathrm{XX}$--XY chimaeric mouse testes: sertoli cells are predominantly, but not exclusively, XY. Development. (1991) 112:265-8.

196. Sekido R, Bar I, Narváez V, Penny G, Lovell-Badge R. SOX9 is up-regulated by the transient expression of SRY specifically in Sertoli cell precursors. Dev Biol. (2004) 274:271-9. doi: 10.1016/j.ydbio.2004.07.011

197. Wilhelm D, Martinson F, Bradford S, Wilson MJ, Combes AN, Beverdam A, et al. Sertoli cell differentiation is induced both cell-autonomously and through prostaglandin signaling during mammalian sex determination. Dev Biol. (2005) 287:111-24. doi: 10.1016/j.ydbio.2005.08.039

198. Sekido R, Lovell-Badge R. Sex determination involves synergistic action of SRY and SF1 on a specific Sox9 enhancer. Nature. (2008) 453:930-4. doi: 10.1038/nature06944

199. Carré G-A, Greenfield A. Characterising novel pathways in testis determination using mouse genetics. Sex Dev. (2014) 8:199-207. doi: $10.1159 / 000358402$

200. Barrionuevo FJ, Burgos M, Scherer G, Jiménez R. Genes promoting and disturbing testis development. Histol Histopathol. (2012) 27:1361-83. doi: $10.14670 / \mathrm{HH}-27.1361$

201. Schmahl J, Eicher EM, Washburn LL, Capel B. Sry induces cell proliferation in the mouse gonad. Development. (2000) 127:65-73.

202. Larney C, Bailey TL, Koopman P. Switching on sex: transcriptional regulation of the testis-determining gene Sry. Development. (2014) 141:2195205. doi: $10.1242 / \operatorname{dev} .107052$

203. Huckins C. The spermatogonial stem cell population in adult rats. I. Their morphology, proliferation and maturation. Anat Rec. (1971) 169:533-57. doi: 10.1002/ar.1091690306

204. Oakberg EF. Spermatogonial stem-cell renewal in the mouse. Anat Rec. (1971) 169:515-531. doi: 10.1002/ar.1091690305 
205. Huckins C, Oakberg EF. Morphological and quantitative analysis of spermatogonia in mouse testes using whole mounted seminiferous tubules. I. The normal testes. Anat Rec. (1978) 192:519-27. doi: 10.1002/ar.1091920406

206. Schrans-Stassen BHGJ, van de Kant HJG, de Rooij DG, van Pelt AMM. Differential expression of c- kit in mouse undifferentiated and differentiating. Endocrinology. (1999) 140:5894-900. doi: 10.1210/endo.140.12.7172

207. Yoshinaga K, Nishikawa S, Ogawa M, Hayashi S, Kunisada T, Fujimoto $\mathrm{T}$, et al. Role of c-kit in mouse spermatogenesis: identification of spermatogonia as a specific site of c-kit expression and function. Development. (1991) 113:689-99.

208. Buaas FW, Kirsh AL, Sharma M, McLean DJ, Morris JL, Griswold MD, et al. Plzf is required in adult male germ cells for stem cell self-renewal. Nat Genet. (2004) 36:647-52. doi: 10.1038/ng1366

209. Costoya JA, Hobbs RM, Barna M, Cattoretti G, Manova K, Sukhwani M, et al. Essential role of Plzf in maintenance of spermatogonial stem cells. Nat Genet. (2004) 36:653-9. doi: 10.1038/ng1367

210. Tolkunova EN, Malashicheva AB, Chikhirzhina EV, Kostyleva EI, Zeng W, Luo J, et al. E-cadherin as a novel surface marker of spermatogonial stem cells. Cell Tissue Biol. (2009) 3:103-9. doi: 10.1134/S1990519X09020011

211. Nakagawa T, Sharma M, Nabeshima YI, Braun RE, Yoshida S. Functional hierarchy and reversibility within the murine spermatogenic stem cell compartment. Science. (2010) 328:62-67. doi: 10.1126/science.1182868

212. Hofmann MC, Braydich-Stolle L, Dym M. Isolation of male germline stem cells; influence of GDNF. Dev Biol. (2005) 279:114-24. doi: 10.1016/j.ydbio.2004.12.006

213. Yoshida S, Takakura A, Ohbo K, Abe K, Wakabayashi J, Yamamoto M, et al. Neurogenin3 delineates the earliest stages of spermatogenesis in the mouse testis. Dev Biol. (2004) 269:447-58. doi: 10.1016/j.ydbio.2004.01.036

214. Suzuki H, Sada A, Yoshida S, Saga Y. The heterogeneity of spermatogonia is revealed by their topology and expression of marker proteins including the germ cell-specific proteins Nanos2 and Nanos3. Dev Biol. (2009) 336:222-31. doi: 10.1016/j.ydbio.2009.10.002

215. Park K-E, Kaucher AV, Powell A, Waqas MS, Sandmaier SES, Oatley MJ, et al. Generation of germline ablated male pigs by CRISPR/Cas9 editing of the NANOS2 gene. Sci Rep. (2017) 7:40176. doi: 10.1038/srep40176

216. Hara K, Nakagawa T, Enomoto H, Suzuki M, Yamamoto M, Simons BD, et al. Mouse spermatogenic stem cells continually interconvert between equipotent singly isolated and syncytial states. Cell Stem Cell. (2014) 14:65872. doi: 10.1016/j.stem.2014.01.019

217. Nakagawa T, Nabeshima Y, Yoshida S. Functional identification of the actual and potential stem cell compartments in mouse spermatogenesis. Dev Cell. (2007) 12:195-206. doi: 10.1016/j.devcel.2007.01.002

218. Carrieri C, Comazzetto S, Grover A, Morgan M, Buness A, Nerlov C, et al. A transit-amplifying population underpins the efficient regenerative capacity of the testis. J Exp Med. (2017) 214:1631-41. doi: 10.1084/jem.20161371

219. La HM, Mäkelä J-A, Chan A-L, Rossello FJ, Nefzger CM, Legrand JMD, et al. Identification of dynamic undifferentiated cell states within the male germline. Nat Commun. (2018) 9:2819. doi: 10.1038/s41467-018-04827-z

220. Abid SN, Richardson TE, Powell HM, Jaichander P, Chaudhary J, Chapman $\mathrm{KM}$, et al. A-single spermatogonia heterogeneity and cell cycles synchronize with rat seminiferous epithelium stages VIII-IX1. Biol Reprod. (2014) 90:115. doi: 10.1095/biolreprod.113.113555

221. Chan F, Oatley MJ, Kaucher AV, Yang Q-E, Bieberich CJ, Shashikant CS, et al. Functional and molecular features of the Id $4+$ germline stem cell population in mouse testes. Genes Dev. (2014) 28:1351-62. doi: 10.1101/gad.2404 65.114

222. Tokue M, Ikami K, Mizuno S, Takagi C, Miyagi A, Takada R, et al. SHISA6 confers resistance to differentiation-promoting Wnt/ $\beta$-catenin signaling in mouse spermatogenic stem cells. Stem Cell Rep. (2017) 8:561-75. doi: 10.1016/j.stemcr.2017.01.006

223. Chiarini-Garcia H, Hornick JR, Griswold MD, Russell LD. Distribution of type A spermatogonia in the mouse is not Random1. Biol Reprod. (2001) 65:1179-85. doi: 10.1095/biolreprod65.4.1179

224. Chiarini-Garcia H, Raymer AM, Russell LD. Non-random distribution of spermatogonia in rats: evidence of niches in the seminiferous tubules. Reproduction. (2003) 126:669-80. doi: 10.1530/reprod/126.5.669
225. Yoshida S, Sukeno M, Nabeshima Y-I. A vasculature-associated niche for undifferentiated spermatogonia in the mouse testis. Science. (2007) 317:1722-6. doi: 10.1126/science.1144885

226. Masaki K, Sakai M, Kuroki S, Jo J-I, Hoshina K, Fujimori Y, et al. FGF2 has distinct molecular functions from GDNF in the mouse germline niche. Stem Cell Rep. (2018) 10:1782-92. doi: 10.1016/j.stemcr.2018.03.016

227. Raatikainen-ahokas A, Sainio K, Rauvala H, Pichel G, Westphal H, Saarma $\mathrm{M}$, et al. Regulation of cell fate decision of undifferentiated spermatogonia by GDNF. Science. (2000) 287:1489-93. doi: 10.1126/science.287.545 7.1489

228. Lee J, Kanatsu-Shinohara M, Inoue K, Ogonuki N, Miki H, Toyokuni S, et al. Akt mediates self-renewal division of mouse spermatogonial stem cells. Development. (2007) 134:1853-9. doi: 10.1242/dev.003004

229. Braydich-Stolle L, Kostereva N, Dym M, Hofmann M-C. Role of Src family kinases and N-Myc in spermatogonial stem cell proliferation. Dev Biol. (2007) 304:34-45. doi: 10.1016/j.ydbio.2006.12.013

230. Garcia TX, Farmaha JK, Kow S, Hofmann M-C. RBPJ in mouse Sertoli cells is required for proper regulation of the testis stem cell niche. Development. (2014) 141:4468-78. doi: 10.1242/dev.113969

231. Garcia TX, Parekh P, Gandhi P, Sinha K, Hofmann M-C. The NOTCH ligand JAG1 regulates GDNF expression in sertoli cells. Stem Cells Dev. (2017) 26:585-98. doi: $10.1089 / \mathrm{scd} .2016 .0318$

232. Sugimoto R, Nabeshima Y, Yoshida S. Retinoic acid metabolism links the periodical differentiation of germ cells with the cycle of Sertoli cells in mouse seminiferous epithelium. Mech Dev. (2012) 128:610-24. doi: 10.1016/j.mod.2011.12.003

233. Vernet N, Dennefeld C, Rochette-Egly C, Oulad-Abdelghani M, Chambon $\mathrm{P}$, Ghyselinck NB, et al. Retinoic acid metabolism and signaling pathways in the adult and developing mouse testis. Endocrinology. (2006) 147:96-110. doi: 10.1210/en.2005-0953

234. Ikami K, Tokue M, Sugimoto R, Noda C, Kobayashi S, Hara K, et al. Hierarchical differentiation competence in response to retinoic acid ensures stem cell maintenance during mouse spermatogenesis. Development. (2015) 142:1582-92. doi: 10.1242/dev.118695

235. Ishii K, Kanatsu-Shinohara M, Toyokuni S, Shinohara T. FGF2 mediates mouse spermatogonial stem cell self-renewal via upregulation of Etv5 and Bcl6b through MAP2K1 activation. Development. (2012) 139:1734-43. doi: $10.1242 / \mathrm{dev} .076539$

236. Zhang Y, Wang S, Wang X, Liao S, Wu Y, Han C. Endogenously produced FGF2 is essential for the survival and proliferation of cultured mouse spermatogonial stem cells. Cell Res. (2012) 22:773-6. doi: 10.1038/cr.2012.17

237. Takase HM, Nusse R. Paracrine $W n t / \beta$-catenin signaling mediates proliferation of undifferentiated spermatogonia in the adult mouse testis. Proc Natl Acad Sci USA. (2016) 113:E1489-97. doi: 10.1073/pnas.1601461113

238. Chassot AA, Le Rolle M, Jourden M, Taketo MM, Ghyselinck NB, Chaboissier MC. Constitutive WNT/CTNNB1 activation triggers spermatogonial stem cell proliferation and germ cell depletion. Dev Biol. (2017) 426:17-27. doi: 10.1016/j.ydbio.2017.04.010

239. Brehm R, Zeiler M, Rüttinger C, Herde K, Kibschull M, Winterhager E, et al. A sertoli cell-specific knockout of Connexin43 prevents initiation of spermatogenesis. Am J Pathol. (2007) 171:19-31. doi: 10.2353/ajpath.2007.061171

240. Payne CJ, Gallagher SJ, Foreman O, Dannenberg JH, Depinho RA, Braun RE. Sin3a is required by sertoli cells to establish a niche for undifferentiated spermatogonia, germ cell tumors, and spermatid elongation. Stem Cells. (2010) 28:1424-34. doi: 10.1002/stem.464

241. Li H, MacLean G, Cameron D, Clagett-Dame M, Petkovich M. Cyp26b1 expression in murine sertoli cells is required to maintain male germ cells in an undifferentiated state during embryogenesis. PLoS ONE. (2009) 4:e7501. doi: 10.1371/journal.pone.0007501

242. MacLean G, Li H, Metzger D, Chambon P, Petkovich M. Apoptotic extinction of germ cells in testes of Cyp26b1 knockout mice. Endocrinology. (2007) 148:4560-7. doi: 10.1210/en.2007-0492

243. Chen C, Ouyang W, Grigura V, Zhou Q, Carnes K, Lim H, et al. ERM is required for transcriptional control of the spermatogonial stem cell niche. Nature. (2005) 436:1030-4. doi: 10.1038/nature03894 
244. Simon MC, Keith B. The role of oxygen availability in embryonic development and stem cell function. Nat Rev Mol Cell Biol. (2008) 9:285-96. doi: $10.1038 / \mathrm{nrm} 2354$

245. Takahashi N, Davy PMC, Gardner LH, Mathews J, Yamazaki Y, Allsopp RC. Hypoxia inducible factor 1 alpha is expressed in germ cells throughout the murine life cycle. PLoS ONE. (2016) 11:e0154309. doi: 10.1371/journal.pone.0154309

246. Clermont Y. Spermatogenesis in man. A study of the spermatogonial population. Fertil Steril. (1966) 17:705-21. doi: 10.1016/S0015-0282(16)36120-9

247. Wu X, Schmidt JA, Avarbock MR, Tobias JW, Carlson CA, Kolon TF, et al. Prepubertal human spermatogonia and mouse gonocytes share conserved gene expression of germline stem cell regulatory molecules. Proc Natl Acad Sci USA. (2009) 106:21672-7. doi: 10.1073/pnas.0912432106

248. He Z, Kokkinaki M, Jiang J, Dobrinski I, Dym M. Isolation, characterization, and culture of human Spermatogonia1. Biol Reprod. (2010) 82:363-72. doi: 10.1095/biolreprod.109.078550

249. Wang M, Liu X, Chang G, Chen Y, An G, Yan L, et al. Singlecell RNA sequencing analysis reveals sequential cell fate transition during human spermatogenesis. Cell Stem Cell. (2018) 23:599-614.e4. doi: 10.1016/j.stem.2018.08.007

250. Guo J, Grow EJ, Mlcochova H, Maher GJ, Lindskog C, Nie X, et al. The adult human testis transcriptional cell atlas. Cell Res. (2018) 28:1141-57. doi: 10.1038/s41422-018-0099-2

251. Hermann BP, Cheng K, Singh A, Roa-De La Cruz L, Mutoji KN, Chen I$\mathrm{C}$, et al. The mammalian spermatogenesis single-cell transcriptome, from spermatogonial stem cells to spermatids. Cell Rep. (2018) 25:1650-67.e8. doi: 10.1016/j.celrep.2018.10.026

252. Tan K, Wilkinson MF. Human spermatogonial stem cells scrutinized under the single-cell magnifying glass. Cell Stem Cell. (2019) 24:201-3. doi: 10.1016/j.stem.2019.01.010

253. Ye L, Li X, Li L, Chen H, Ge R-S. Insights into the development of the adult leydig cell lineage from stem leydig cells. Front Physiol. (2017) 8:430. doi: 10.3389/fphys.2017.00430

254. Stanley E, Lin C-Y, Jin S, Liu J, Sottas CM, Ge R, et al. Identification, proliferation, and differentiation of adult leydig stem cells. Endocrinology. (2012) 153:5002-10. doi: 10.1210/en.2012-1417

255. Guo J, Zhou H, Su Z, Chen B, Wang G, Wang CQF, et al. Comparison of cell types in the rat Leydig cell lineage after ethane dimethanesulfonate treatment. Reproduction. (2013) 145:371-80. doi: 10.1530/REP-12-0465

256. Mo J, Chen X, Ni C, Wu K, Li X, Zhu Q, et al. Fibroblast growth factor homologous factor 1 stimulates Leydig cell regeneration from stem cells in male rats. J Cell Mol Med. (2019) 23:5618-31. doi: 10.1111/jcmm.14461

257. Rebourcet D, O’Shaughnessy PJ, Pitetti J-L, Monteiro A, O’Hara L, Milne L, et al. Sertoli cells control peritubular myoid cell fate and support adult Leydig cell development in the prepubertal testis. Development. (2014) 141:2139-49. doi: 10.1242/dev.107029

258. Kanatsu-Shinohara M, Kanatsu-Shinohara M, Inoue K, Inoue K, Lee J, Lee J, et al. Generation of pluripotent stem cells from neonatal mouse testis. Cell. (2004) 119:1001-12. doi: 10.1016/j.cell.2004.11.011

259. Golestaneh N, Kokkinaki M, Pant D, Jiang J, DeStefano D, Fernandez-Bueno C, et al. Pluripotent stem cells derived from adult human testes. Stem Cells Dev. (2009) 18:1115-25. doi: 10.1089/scd.2008.0347

260. Kossack N, Meneses J, Shefi S, Nguyen HN, Chavez S, Nicholas $\mathrm{C}$, et al. Isolation and characterization of pluripotent human spermatogonial stem cell-derived cells. Stem Cells. (2009) 27:138-49. doi: 10.1634/stemcells.2008-0439

261. Mizrak SC, Chikhovskaya JV, Sadri-Ardekani H, van Daalen S, Korver CM, Hovingh SE, et al. Embryonic stem cell-like cells derived from adult human testis. Hum Reprod. (2010) 25:158-67. doi: 10.1093/humrep/dep354

262. Brinster RL, Zimmermann JW. Spermatogenesis following male germ-cell transplantation. Dev Biol. (1994) 91:11298-302. doi: 10.1073/pnas.91.24.11298

263. Nagano M, Patrizio P, Brinster RL. Long-term survival of human spermatogonial stem cells in mouse testes. Fertil Steril. (2002) 78:1225-33. doi: 10.1016/S0015-0282(02)04345-5

264. Sadri-Ardekani H. Propagation of human spermatogonial stem cells in vitro. JAMA. (2009) 302:2127. doi: 10.1001/jama.2009.1689
265. Sadri-Ardekani H. In vitro propagation of human prepubertal spermatogonial stem cells. JAMA. (2011) 305:2416. doi: $10.1001 /$ jama.2011.791

266. Abu Elhija M, Lunenfeld E, Schlatt S, Huleihel M. Differentiation of murine male germ cells to spermatozoa in a soft agar culture system. Asian J Androl. (2012) 14:285-93. doi: 10.1038/aja.2011.112

267. Sato T, Katagiri K, Gohbara A, Inoue K, Ogonuki N, Ogura A, et al. In vitro production of functional sperm in cultured neonatal mouse testes. Nature. (2011) 471:504-7. doi: 10.1038/nature09850

268. Gohbara A, Katagiri K, Sato T, Kubota Y, Kagechika H, Araki Y, et al. In vitro murine spermatogenesis in an organ culture System1. Biol Reprod. (2010) 83:261-7. doi: 10.1095/biolreprod.110.083899

269. Sato T, Katagiri K, Kubota Y, Ogawa T. In vitro sperm production from mouse spermatogonial stem cell lines using an organ culture method. Nat Protoc. (2013) 8:2098-104. doi: 10.1038/nprot.2013.138

270. Richards JS, Pangas SA. The ovary: basic biology and clinical implications. $J$ Clin Invest. (2010) 120:963-72. doi: 10.1172/JCI41350

271. Grive KJ, Freiman RN. The developmental origins of the mammalian ovarian reserve. Development. (2015) 142:2554-63. doi: 10.1242/dev.125211

272. Tingen C, Kim A, Woodruff TK. The primordial pool of follicles and nest breakdown in mammalian ovaries. Mol Hum Reprod. (2009) 15:795-803. doi: 10.1093/molehr/gap073

273. Lei L, Spradling AC. Mouse primordial germ cells produce cysts that partially fragment prior to meiosis. Development. (2013) 140:2075-81. doi: 10.1242/dev.093864

274. Pepling ME. Follicular assembly: mechanisms of action. Reproduction. (2012) 143:139-49. doi: 10.1530/REP-11-0299

275. Vainio S, Heikkilä M, Kispert A, Chin N, McMahon AP. Female development in mammals is regulated by Wnt-4 signalling. Nature. (1999) 397:405-9. doi: $10.1038 / 17068$

276. Parma P, Radi O, Vidal V, Chaboissier MC, Dellambra E, Valentini S, et al. R-spondin 1 is essential in sex determination, skin differentiation and malignancy. Nat Genet. (2006) 38:1304-9. doi: 10.1038/ng1907

277. Tomizuka K, Horikoshi K, Kitada R, Sugawara Y, Iba Y, Kojima A, et al. R-spondin1 plays an essential role in ovarian development through positively regulating Wnt-4 signaling. Hum Mol Genet. (2008) 17:1278-91. doi: $10.1093 / \mathrm{hmg} / \mathrm{ddn} 036$

278. Schmidt D, Ovitt CE, Anlag K, Fehsenfeld S, Gredsted L, Treier A-C, et al. The murine winged-helix transcription factor Foxl2 is required for granulosa cell differentiation and ovary maintenance. Development. (2004) 131:933-42. doi: 10.1242/dev.00969

279. Uda M, Ottolenghi C, Crisponi L, Garcia JE, Deiana M, Kimber $\mathrm{W}$, et al. Foxl2 disruption causes mouse ovarian failure by pervasive blockage of follicle development. Hum Mol Genet. (2004) 13:1171-81. doi: $10.1093 / \mathrm{hmg} / \mathrm{ddh} 124$

280. Ottolenghi C, Pelosi E, Tran J, Colombino M, Douglass E, Nedorezov T, et al. Loss of Wnt4 and Foxl2 leads to female-to-male sex reversal extending to germ cells. Hum Mol Genet. (2007) 16:2795-804. doi: 10.1093/hmg/ddm235

281. Zuckerman SLZ. The number of oocytes in the mature ovary. Recent Prog Horm Res. (1951) 6:63-109.

282. Johnson J, Canning J, Kaneko T, Pru JK, Tilly JL. Germline stem cells and follicular renewal in the postnatal mammalian ovary. Nature. (2004) 428:145-50. doi: 10.1038/nature02316

283. Gougeon A, Notarianni E. There is no neo-oogenesis in the adult mammalian ovary. J Turkish Ger Gynecol Assoc. (2011) 12:270-3. doi: $10.5152 /$ jtgga.2011.63

284. Notarianni E. Reinterpretation of evidence advanced for neo-oogenesis in mammals, in terms of a finite oocyte reserve. J Ovarian Res. (2011) 4:1. doi: 10.1186/1757-2215-4-1

285. Martin J, Woods D, Tilly J. Implications and current limitations of oogenesis from female germline or oogonial stem cells in adult mammalian ovaries. Cells. (2019) 8:93. doi: 10.3390/cells8020093

286. Zou K, Yuan Z, Yang Z, Luo H, Sun K, Zhou L, et al. Production of offspring from a germline stem cell line derived from neonatal ovaries. Nat Cell Biol. (2009) 11:631-6. doi: 10.1038/ncb1869

287. Zhang C, Wu J. Production of offspring from a germline stem cell line derived from prepubertal ovaries of germline reporter mice. Mol Hum Reprod. (2016) 22:457-64. doi: 10.1093/molehr/gaw030 
288. Woods DC, Tilly JL. Isolation, characterization and propagation of mitotically active germ cells from adult mouse and human ovaries. Nat Protoc. (2013) 8:966-88. doi: 10.1038/nprot.2013.047

289. Niikura Y, Niikura T, Tilly JL. Aged mouse ovaries possess rare premeiotic germ cells that can generate oocytes following transplantation into a young host environment. Aging. (2009) 1:971-8. doi: 10.18632/aging.1 00105

290. Gong SP, Lee ST, Lee EJ, Kim DY, Lee G, Chi SG, et al. Embryonic stem celllike cells established by culture of adult ovarian cells in mice. Fertil Steril. (2010) 93:2594-601.e9. doi: 10.1016/j.fertnstert.2009.12.053

291. Pacchiarotti J, Maki C, Ramos T, Marh J, Howerton K, Wong $J$, et al. Differentiation potential of germ line stem cells derived from the postnatal mouse ovary? Differentiation. (2010) 79:159-70. doi: 10.1016/j.diff.2010.01.001

292. Wang H, Jiang M, Bi H, Chen X, He L, Li X, et al. Conversion of female germline stem cells from neonatal and prepubertal mice into pluripotent stem cells. J Mol Cell Biol. (2014) 6:164-71. doi: 10.1093/jmcb/mju004

293. Khosravi-Farsani S, Amidi F, Roudkenar MH, Sobhani A. Isolation and enrichment of mouse female germ line stem cells. Cell J. (2015) 16:406-15.

294. Xiong J, Lu Z, Wu M, Zhang J, Cheng J, Luo A, et al. Intraovarian transplantation of female germline stem cells rescue ovarian function in chemotherapy-injured ovaries. PLoS ONE. (2015) 10:e0139824. doi: 10.1371/journal.pone.0139824

295. Park E-S, Tilly JL. Use of DEAD-box polypeptide-4 (Ddx4) gene promoterdriven fluorescent reporter mice to identify mitotically active germ cells in post-natal mouse ovaries. MHR Basic Sci Reprod Med. (2015) 21:58-65. doi: 10.1093/molehr/gau071

296. Wu C, Xu B, Li X, Ma W, Zhang P, Chen X, et al. Tracing and characterizing the development of transplanted female germline stem cells in vivo. Mol Ther. (2017) 25:1408-19. doi: 10.1016/j.ymthe.2017.04.019

297. Bhartiya D, Sriraman K, Parte S, Patel H. Ovarian stem cells: absence of evidence is not evidence of absence. J Ovarian Res. (2013) 6:65. doi: $10.1186 / 1757-2215-6-65$

298. Zhang H, Zheng W, Shen Y, Adhikari D, Ueno H, Liu K. Experimental evidence showing that no mitotically active female germline progenitors exist in postnatal mouse ovaries. Proc Natl Acad Sci USA. (2012) 109:12580-5. doi: $10.1073 /$ pnas. 1206600109

299. Lei L, Spradling AC. Female mice lack adult germ-line stem cells but sustain oogenesis using stable primordial follicles. Proc Natl Acad Sci USA. (2013) 110:8585-90. doi: 10.1073/pnas.1306189110

300. Zhang H, Panula S, Petropoulos S, Edsgärd D, Busayavalasa K, Liu L, et al. Adult human and mouse ovaries lack DDX4-expressing functional oogonial stem cells. Nat Med. (2015) 21:1116-8. doi: 10.1038/nm.3775

301. Guo K, Li C, Wang X, He D, Zheng P. Germ stem cells are active in postnatal mouse ovary under physiological conditions. Mol Hum Reprod. (2016) 22:316-28. doi: 10.1093/molehr/gaw015

302. Wang N, Satirapod C, Ohguchi Y, Park E-S, Woods DC, Tilly JL. Genetic studies in mice directly link oocytes produced during adulthood to ovarian function and natural fertility. Sci Rep. (2017) 7:10011. doi: 10.1038/s41598-017-10033-6

303. White YAR, Woods DC, Takai Y, Ishihara O, Seki H, Tilly JL. Oocyte formation by mitotically active germ cells purified from ovaries of reproductive-age women. Nat Med. (2012) 18:413-21. doi: 10.1038/nm.2669

304. Ding X, Liu G, Xu B, Wu C, Hui N, Ni X, et al. Human GV oocytes generated by mitotically active germ cells obtained from follicular aspirates. Sci Rep. (2016) 6:28218. doi: 10.1038/srep28218

305. Clarkson YL, McLaughlin M, Waterfall M, Dunlop CE, Skehel PA, Anderson RA, et al. Initial characterisation of adult human ovarian cell populations isolated by DDX4 expression and aldehyde dehydrogenase activity. Sci Rep. (2018) 8:6953. doi: 10.1038/s41598-018-25116-1

306. Silvestris E, Cafforio P, D’Oronzo S, Felici C, Silvestris F, Loverro G. In vitro differentiation of human oocyte-like cells from oogonial stem cells: singlecell isolation and molecular characterization. Hum Reprod. (2018) 33:46473. doi: 10.1093/humrep/dex377

307. Dunlop CE, Bayne RA, McLaughlin M, Telfer EE, Anderson RA. Isolation, purification, and culture of oogonial stem cells from adult human and bovine ovarian cortex. Lancet. (2014) 383:S45. doi: 10.1016/S0140-6736(14)60308-1
308. Zhang X, Yang $\mathrm{Y}$, Xia Q, Song $\mathrm{H}$, Wei R, Wang J, et al. Cadherin 22 participates in the self-renewal of mouse female germ line stem cells via interaction with JAK2 and $\beta$-catenin. Cell Mol Life Sci. (2018) 75:1241-53. doi: 10.1007/s00018-017-2689-4

309. Zhang X, Wei R, Sun Y, Xia Q, Xie W, Song H, et al.. AKT3 is a pivotal molecule of cadherin-22 and GDNF family receptor- $\alpha 1$ signal pathways regulating self-renewal in female germline stem cells. Stem Cells. (2019) 37:1095-107. doi: 10.1002/stem.3030

310. Johnson J, Bagley J, Skaznik-Wikiel M, Lee H-J, Adams GB, Niikura Y, et al. Oocyte generation in adult mammalian ovaries by putative germ cells in bone marrow and peripheral blood. Cell. (2005) 122:303-15. doi: 10.1016/j.cell.2005.06.031

311. Eggan K, Jurga S, Gosden R, Min IM, Wagers AJ. Ovulated oocytes in adult mice derive from non-circulating germ cells. Nature. (2006) 441:1109-14. doi: 10.1038 /nature 04929

312. Lee H-J, Selesniemi K, Niikura Y, Niikura T, Klein R, Dombkowski $\mathrm{DM}$, et al. Bone marrow transplantation generates immature oocytes and rescues long-term fertility in a preclinical mouse model of chemotherapyinduced premature ovarian failure. J Clin Oncol. (2007) 25:3198-204. doi: 10.1200/JCO.2006.10.3028

313. Herraiz S, Buigues A, Díaz-García C, Romeu M, Martínez S, GómezSeguí I, et al. Fertility rescue and ovarian follicle growth promotion by bone marrow stem cell infusion. Fertil Steril. (2018) 109:908-18.e2. doi: 10.1016/j.fertnstert.2018.01.004

314. Honda $\mathrm{A}$, Hirose $\mathrm{M}$, Hara $\mathrm{K}$, Matoba $\mathrm{S}$, Inoue $\mathrm{K}$, Miki $\mathrm{H}$, et al. Isolation, characterization, and in vitro and in vivo differentiation of putative thecal stem cells. Proc Natl Acad Sci USA. (2007) 104:12389-94. doi: 10.1073/pnas.0703787104

315. Virant-Klun I, RoŽman P, Cvjeticanin B, Vrtacnik-Bokal E, Novakovic $S$, Rülicke T, et al. Parthenogenetic embryo-like structures in the human ovarian surface epithelium cell culture in postmenopausal women with no naturally present follicles and oocytes. Stem Cells Dev. (2009) 18:137-50. doi: $10.1089 /$ scd.2007.0238

316. Virant-Klun I, Zech N, RoŽman P, Vogler A, Cvjetičanin B, Klemenc P, et al. Putative stem cells with an embryonic character isolated from the ovarian surface epithelium of women with no naturally present follicles and oocytes. Differentiation. (2008) 76:843-56. doi: 10.1111/j.1432-0436.2008.00268.x

317. Xu J, Zheng $\mathrm{T}$, Hong $\mathrm{W}$, Ye $\mathrm{H}$, Hu C, Zheng Y. Mechanism for the decision of ovarian surface epithelial stem cells to undergo neooogenesis or ovarian tumorigenesis. Cell Physiol Biochem. (2018) 50:214-32. doi: $10.1159 / 000494001$

318. Woods D, Tilly J. Autologous Germline Mitochondrial Energy Transfer (AUGMENT) in human assisted reproduction. Semin Reprod Med. (2015) 33:410-21. doi: 10.1055/s-0035-1567826

319. Da Silva Xavier G. The cells of the islets of langerhans. J Clin Med. (2018) 7:54. doi: $10.3390 / \mathrm{jcm} 7030054$

320. Pan FC, Wright C. Pancreas organogenesis: from bud to plexus to gland. Dev Dyn. (2011) 240:530-65. doi: 10.1002/dvdy.22584

321. Pan FC, Brissova M. Pancreas development in humans. Curr Opin Endocrinol Diabetes Obes. (2014) 21:77-82. doi: 10.1097/MED.0000000000000047

322. Shih HP, Wang A, Sander M. Pancreas organogenesis: from lineage determination to morphogenesis. Annu Rev Cell Dev Biol. (2013) 29:81-105. doi: 10.1146/annurev-cellbio-101512-122405

323. Ye F, Duvillié B, Scharfmann R. Fibroblast growth factors 7 and 10 are expressed in the human embryonic pancreatic mesenchyme and promote the proliferation of embryonic pancreatic epithelial cells. Diabetologia. (2005) 48:277-81. doi: 10.1007/s00125-004-1638-6

324. Jørgensen MC, Ahnfelt-Rønne J, Hald J, Madsen OD, Serup P, HecksherSørensen J. An illustrated review of early pancreas development in the mouse. Endocr Rev. (2007) 28:685-705. doi: 10.1210/er.20 07-0016

325. Burlison JS, Long Q, Fujitani Y, Wright CVE, Magnuson MA. Pdx-1 and Ptfla concurrently determine fate specification of pancreatic multipotent progenitor cells. Dev Biol. (2008) 316:74-86. doi: 10.1016/j.ydbio.2008.01.011

326. Haumaitre C, Barbacci E, Jenny M, Ott MO, Gradwohl G, Cereghini S. Lack of TCF2/vHNF1 in mice leads to pancreas agenesis. Proc Natl Acad Sci USA. (2005) 102:1490-5. doi: 10.1073/pnas.0405776102 
327. Henseleit KD. NKX6 transcription factor activity is required for - and -cell development in the pancreas. Development. (2005) 132:3139-49. doi: 10.1242/dev.01875

328. Kawaguchi Y, Cooper B, Gannon M, Ray M, MacDonald RJ, Wright CVE. The role of the transcriptional regulator Ptfla in converting intestinal to pancreatic progenitors. Nat Genet. (2002) 32:128-34. doi: 10.1038/ng959

329. Kopp JL, Dubois CL, Hao E, Thorel F, Herrera PL, Sander M. Progenitor cell domains in the developing and adult pancreas. Cell Cycle. (2011) 10:1921-7. doi: $10.4161 /$ cc.10.12.16010

330. Seymour PA, Sander M. Immunohistochemical detection of betagalactosidase or green fluorescent protein on tissue sections. Methods Mol Biol. (2007) 411:13-23. doi: 10.1007/978-1-59745-549-7_2

331. Solar M, Cardalda C, Houbracken I, Martín M, Maestro MA, De Medts $\mathrm{N}$, et al. Pancreatic exocrine duct cells give rise to insulin-producing $\beta$ cells during embryogenesis but not after birth. Dev Cell. (2009) 17:849-60. doi: 10.1016/j.devcel.2009.11.003

332. Zhou Q, Law AC, Rajagopal J, Anderson WJ, Gray PA, Melton DA. A multipotent progenitor domain guides pancreatic organogenesis. Dev Cell. (2007) 13:103-14. doi: 10.1016/j.devcel.2007.06.001

333. Sander N, Sussel L, Conners J, Scheel D, Kalamaras J, Dela Cruz F, et al. Homeobox gene Nkx6.1 lies downstream of Nkx2.2 in the major pathway of $\beta$-cell formation in the pancreas. Development. (2000) 127:5533-40.

334. Schaffer AE, Freude KK, Nelson SB, Sander M. Nkx6 transcription factors and Ptfla function as antagonistic lineage determinants in multipotent pancreatic progenitors. Dev Cell. (2010) 18:1022-9. doi: 10.1016/j.devcel.2010.05.015

335. Gu G, Dubauskaite J, Melton DA. Direct evidence for the pancreatic lineage: NGN3 + cells are islet progenitors and are distinct from duct progenitors. Development. (2002) 129:2447-57.

336. Lammert E. Induction of pancreatic differentiation by signals from blood vessels. Science. (2001) 294:564-7. doi: 10.1126/science.1064344

337. Heinis M, Simon M-T, Ilc K, Mazure NM, Pouyssegur J, Scharfmann $\mathrm{R}$, et al. Oxygen tension regulates pancreatic -cell differentiation through hypoxia-inducible factor 1. Diabetes. (2010) 59:662-9. doi: 10.2337/db 09-0891

338. Castaing M, Duvillié B, Quemeneur E, Basmaciogullari A, Scharfmann R. Ex vivo analysis of acinar and endocrine cell development in the human embryonic pancreas. Dev Dyn. (2005) 234:339-45. doi: 10.1002/dvdy.20547

339. Apelqvist $\AA$, Li H, Sommer L, Beatus P, Anderson DJ, Honjo T, et al. Notch signalling controls pancreatic cell differentiation. Nature. (1999) 400:877-81. doi: $10.1038 / 23716$

340. Sharon N, Chawla R, Mueller J, Vanderhooft J, Whitehorn LJ, Rosenthal $\mathrm{B}$, et al. A peninsular structure coordinates asynchronous differentiation with morphogenesis to generate pancreatic islets. Cell. (2019) 176:790-804. doi: 10.1016/j.cell.2018.12.003

341. Velazco-Cruz L, Song J, Maxwell KG, Goedegebuure MM, Augsornworawat P, Hogrebe NJ, et al. Acquisition of dynamic function in human stem cell-derived $\beta$ cells. Stem Cell Rep. (2019) 12:351-65. doi: 10.1016/j.stemcr.2018.12.012

342. Rosado-Olivieri EA, Anderson K, Kenty JH, Melton DA. YAP inhibition enhances the differentiation of functional stem cellderived insulin-producing $\beta$ cells. Nat Commun. (2019) 10:1464. doi: 10.1038/s41467-019-09404-6

343. Bechard ME, Bankaitis ED, Hipkens SB, Ustione A, Piston DW, Yang YP, et al. Precommitment low-level neurog3 expression defines a long-lived mitotic endocrine-biased progenitor pool that drives production of endocrine-committed cells. Genes Dev. (2016) 30:1852-65. doi: $10.1101 /$ gad.284729.116

344. Nyeng P, Heilmann S, Löf-Öhlin ZM, Pettersson NF, Hermann FM, Reynolds $\mathrm{AB}$, et al. p120ctn-mediated organ patterning precedes and determines pancreatic progenitor fate. Dev Cell. (2019) 49:31-47.e9. doi: 10.1016/j.devcel.2019.02.005

345. Hard WL. The origin and differentiation of the alpha and beta cells in the pancreatic islets of the rat. Am J Anat. (1944) 75:369-403. doi: 10.1002/aja.1000750305

346. Stanger BZ, Tanaka AJ, Melton DA. Organ size is limited by the number of embryonic progenitor cells in the pancreas but not the liver. Nature. (2007) 445:886-91. doi: 10.1038/nature05537
347. Rankin MM, Kushner JA. Adaptive $\beta$-cell proliferation is severely restricted with advanced age. Diabetes. (2009) 6:1365-72. doi: 10.2337/db08-1198

348. Van Assche FA, Aerts L, De Prins F. A morphological study of the endocrine pancreas in human pregnancy. Br J Obstet Gynaecol. (1978) 85:818-20. doi: 10.1111/j.1471-0528.1978.tb15835.x

349. Zhong F, Jiang Y. Endogenous pancreatic $\beta$ cell regeneration: a potential strategy for the recovery of $\beta$ cell deficiency in diabetes. Front Endocrinol. (2019) 10:101. doi: 10.3389/fendo.2019.00101

350. Li W-C, Rukstalis JM, Nishimura W, Tchipashvili V, Habener JF, Sharma A, et al. Activation of pancreatic-duct-derived progenitor cells during pancreas regeneration in adult rats. J Cell Sci. (2010) 123:2792-802. doi: $10.1242 /$ jcs.065268

351. Sharma A, Zangen DH, Reitz P, Taneja M, Lissauer ME, Miller CP, et al. The homeodomain protein IDX-1 increases after an early burst of proliferation during pancreatic regeneration. Diabetes. (1999) 48:507-13. doi: $10.2337 /$ diabetes.48.3.507

352. Dor Y, Brown J, Martinez OI, Melton DA. Adult pancreatic $\beta$-cells are formed by self-duplication rather than stem-cell differentiation. Nature. (2004) 429:41-6. doi: 10.1038/nature02520

353. Desai BM, Oliver-Krasinski J, De Leon DD, Farzad C, Hong N, Leach SD, et al.. Preexisting pancreatic acinar cells contribute to acinar cell, but not islet $\beta$ cell, regeneration. J Clin Invest. (2007) 117:971-7. doi: 10.1172/ JCI29988

354. Murtaugh LC, Keefe MD. Regeneration and repair of the exocrine pancreas. Annu Rev Physiol. (2015) 77:229-49. doi: 10.1146/annurev-physiol-021014-071727

355. Xiao X, Chen Z, Shiota C, Prasadan K, Guo P, El-Gohary Y, et al. No evidence for $\beta$ cell neogenesis in murine adult pancreas. J Clin Invest. (2013) 123:2207-17. doi: 10.1172/JCI66323

356. Teta M, Rankin MM, Long SY, Stein GM, Kushner JA. Growth and regeneration of adult $\beta$ cells does not involve specialized progenitors. Dev Cell. (2007) 12:817-26. doi: 10.1016/j.devcel.2007.04.011

357. Johnston NR, Mitchell RK, Haythorne E, Pessoa MP, Semplici F, Ferrer J, et al. Beta cell hubs dictate pancreatic islet responses to glucose. Cell Metab. (2016) 24:389-401. doi: 10.1016/j.cmet.2016.06.020

358. Wang YJ, Golson ML, Schug J, Traum D, Liu C, Vivek K, et al. Singlecell mass cytometry analysis of the human endocrine pancreas. Cell Metab. (2016) 24:616-26. doi: 10.1016/j.cmet.2016.09.007

359. Bader E, Migliorini A, Gegg M, Moruzzi N, Gerdes J, Roscioni SS, et al. Identification of proliferative and mature $\beta$-cells in the islets of Langerhans. Nature. (2016) 535:430-4. doi: 10.1038/nature18624

360. Thorel F, Népote V, Avril I, Kohno K, Desgraz R, Chera S, et al. Conversion of adult pancreatic $\alpha$-cells to B-cells after extreme B-cell loss. Nature. (2010) 464:1149-54. doi: 10.1038/nature08894

361. Ben-Othman N, Vieira A, Courtney M, Record F, Gjernes E, Avolio F, et al. Long-term GABA administration induces alpha cell-mediated beta-like cell neogenesis. Cell. (2017) 168:73-85. doi: 10.1016/j.cell.2016.11.002

362. van der Meulen T, Lee S, Noordeloos E, Donaldson CJ, Adams MW, Noguchi GM, et al. Artemether does not turn $\alpha$ cells into $\beta$ cells. Cell Metab. (2018) 27:218-25.e4. doi: 10.1016/j.cmet.2017.10.002

363. Li J, Casteels T, Frogne T, Ingvorsen C, Honoré C, Courtney M, et al. Artemisinins target GABA A receptor signaling and impair $\alpha$ cell identity. Cell. (2017) 168:86-100.e15. doi: 10.1016/j.cell.2016.11.010

364. Smukler SR, Arntfield ME, Razavi R, Bikopoulos G, Karpowicz P, Seaberg $\mathrm{R}$, et al. The adult mouse and human pancreas contain rare multipotent stem cells that express insulin. Cell Stem Cell. (2011) 8:281-93. doi: 10.1016/j.stem.2011.01.015

365. Loomans CJM, Williams Giuliani N, Balak J, Ringnalda F, van Gurp L, Huch M, et al. Expansion of adult human pancreatic tissue yields organoids harboring progenitor cells with endocrine differentiation potential. Stem Cell Rep. (2018) 10:712-24. doi: 10.1016/j.stemcr.2018.02.005

366. D’Amour KA, Agulnick AD, Eliazer S, Kelly OG, Kroon E, Baetge EE. Efficient differentiation of human embryonic stem cells to definitive endoderm. Nat Biotechnol. (2005) 23:1534-41. doi: 10.1038/nbt1163

367. Nostro MC, Sarangi F, Yang C, Holland A, Elefanty AG, Stanley EG, et al. Efficient generation of NKX6-1+ pancreatic progenitors from multiple human pluripotent stem cell lines. Stem Cell Rep. (2015) 4:591-604. doi: 10.1016/j.stemcr.2015.02.017 
368. Kroon E, Martinson LA, Kadoya K, Bang AG, Kelly OG, Eliazer S, et al. Pancreatic endoderm derived from human embryonic stem cells generates glucose-responsive insulin-secreting cells in vivo. Nat Biotechnol. (2008) 26:443-52. doi: 10.1038/nbt1393

369. D’Amour KA, Bang AG, Eliazer S, Kelly OG, Agulnick AD, Smart NG, et al. Production of pancreatic hormone-expressing endocrine cells from human embryonic stem cells. Nat Biotechnol. (2006) 24:1392-401. doi: $10.1038 /$ nbt1259

370. Nair GG, Liu JS, Russ HA, Tran S, Saxton MS, Chen R, et al. Recapitulating endocrine cell clustering in culture promotes maturation of human stem-cell-derived $\beta$ cells. Nat Cell Biol. (2019) 21:263-74. doi: 10.1038/s41556-018-0271-4

371. Rezania A, Bruin JE, Riedel MJ, Mojibian M, Asadi A, Xu J, et al. Maturation of human embryonic stem cell-derived pancreatic progenitors into functional islets capable of treating pre-existing diabetes in mice. Diabetes. (2012) 61:2016-29. doi: 10.2337/db11-1711

372. Rezania A, Bruin JE, Arora P, Rubin A, Batushansky I, Asadi A, et al. Reversal of diabetes with insulin-producingcells derived in vitro from human pluripotent stem cells. Nat Biotechnol. (2014) 32:1121-33. doi: 10.1038/nbt.3033

373. Pagliuca FW, Millman JR, Gürtler M, Segel M, Van Dervort A, Ryu JH, et al. Generation of functional human pancreatic $\beta$ cells in vitro. Cell. (2014) 159:428-39. doi: 10.1016/j.cell.2014.09.040

Conflict of Interest: The authors declare that the research was conducted in the absence of any commercial or financial relationships that could be construed as a potential conflict of interest.

Copyright (C) 2019 Mariniello, Ruiz-Babot, McGaugh, Nicholson, Gualtieri, GastonMassuet, Nostro and Guasti. This is an open-access article distributed under the terms of the Creative Commons Attribution License (CC BY). The use, distribution or reproduction in other forums is permitted, provided the original author $(s)$ and the copyright owner(s) are credited and that the original publication in this journal is cited, in accordance with accepted academic practice. No use, distribution or reproduction is permitted which does not comply with these terms. 